


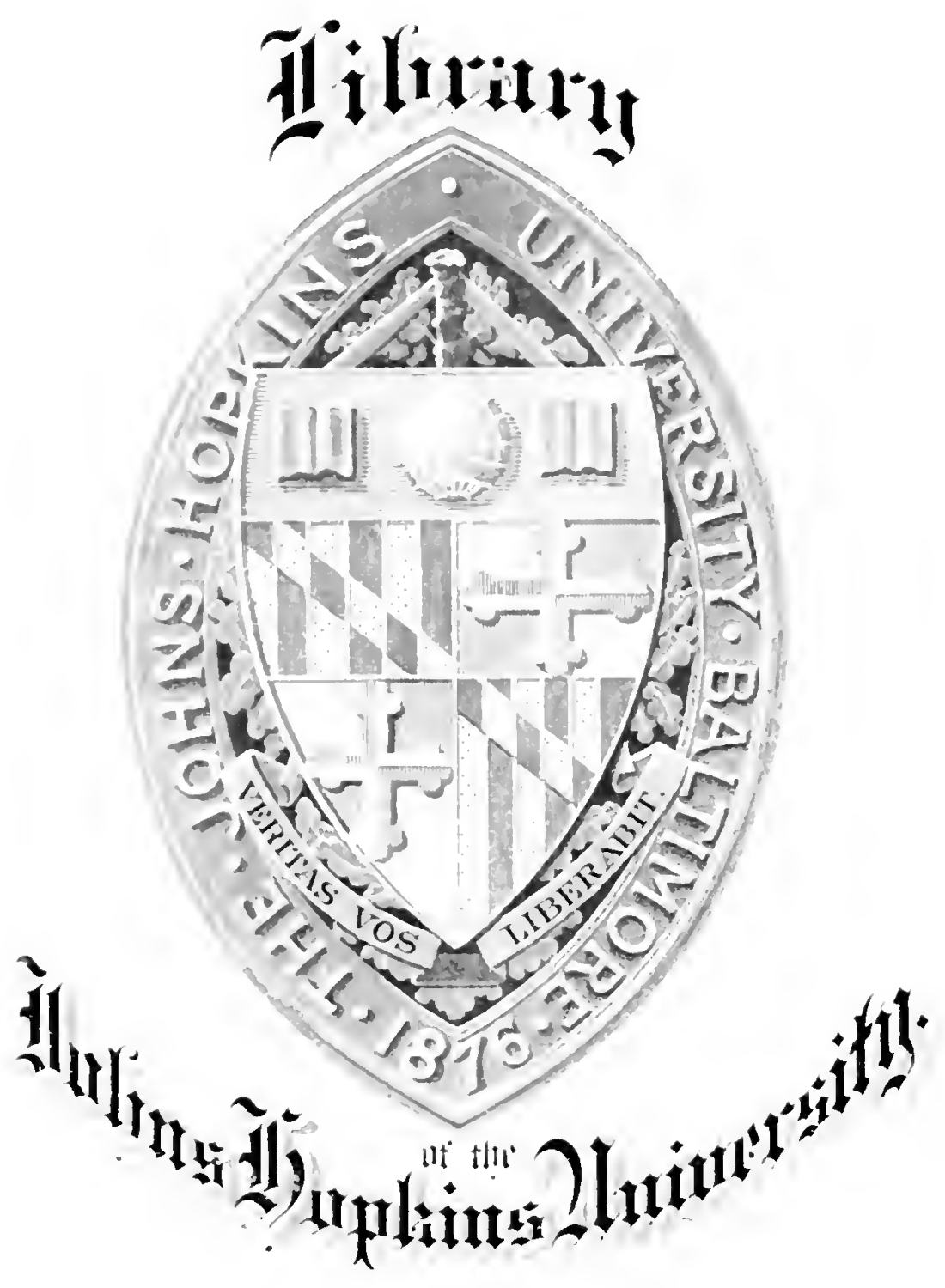




$$
+2
$$



THE EMPLOYMENT OF THE PLEBISCITE IN THE DETERMINATION OF SOVEREIGNTY 



\title{
THE EMPLOYMENT OF THE PLEBISCITE IN THE DETERMINATION OF SOVEREIGNTY
}

\author{
BY \\ JOHANNES MATTERN
}

A DISSERTATION

Submitted to the Board of University Studies of The Johns Hopkins University in conformity with the Requirements for the degree of Doctor of Philosophy

1922

BALTIMORE

1922 
COPYRIGHT $1920 \mathrm{BY}$

THE JOHNS HOPKINS PRESS

PRESS OF
THE NEW ERA PRINING COMPANY LRACRINTRG PA.
LACASTER, PA. 


\section{CONTENTS}

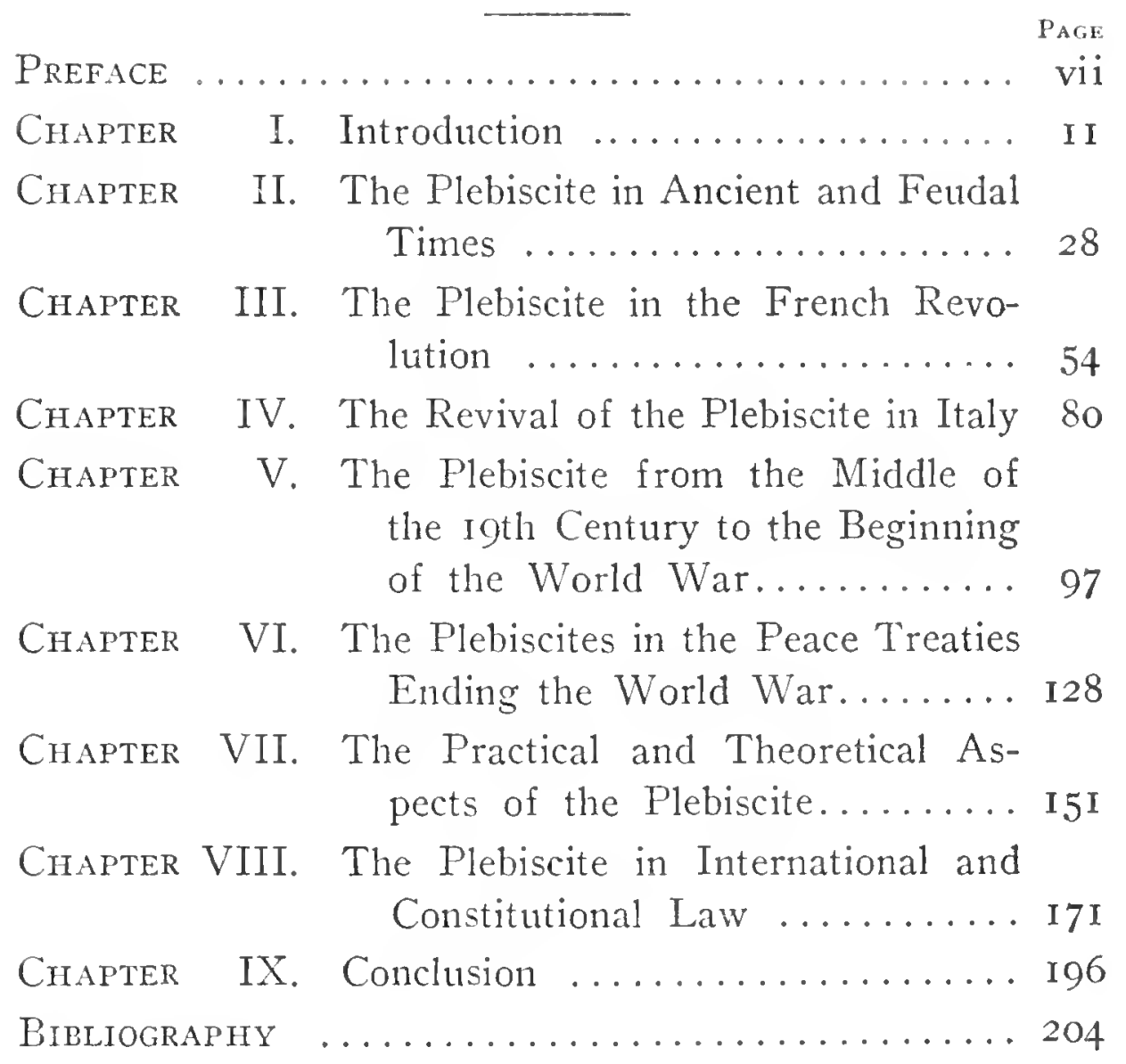





\section{PREFACE}

The employment of the plebiscite in the determination of sovereignty was proclaimed as a government policy by revolutionary France. Since that time the advocates of the doctrine of popular consent as the sine qua non of territorial settlements involving changes of sovereignty have endeavored to secure its universal recognition in theory as well as in practice. In the course of the nineteenth century plebiscites have been held in a number of territorial transfers, resulting in changes of sovereignty without, however, establishing the resort to such popular votes as a general practice in international law.

In the attempt to form an opinion as to the justification of the employment of a plebiscite in the determination of sovereignty, either as a general principle or as a proper mode of settlement in individual cases, we turn instinctively to the past in search of its precedents illustrating the practice of the nations, and for records of opinions of leading statesmen and international jurists.

The present study aims to estimate the evolutionary momentum of the doctrine actually applied, in so far as it is traceable through the mass of alleged or genuine precedents of ancient, feudal, and modern times, and to consider the theoretical and practical aspect of the subject from the point of view of international and constitutional law in the light of more recent developments.

The most complete collection of precedents which a review of the bibliography of the subject seems to offer is found in F. Freudenthal's Die Volksabstimmung bei Gebietsabtretungen und Eroberungen ... Erlangen, I891, and E. Solière's Le Plébiscite dans l'annexion, étude historique et critique de droit des gens, Paris, I901.

The international legal aspect of the question is treated vii 
by most statesmen and international jurists in the briefest fashon, amonting to practically nothing more than an expression of a favorable or unfavorable view.

Frendenthal, and before him Stoerk in his Option und Pleliscit bei Erobermingen und Gebictsessionen . . . , Leipzig. I 879 , discusses in some detail the historical development and the constitutional and international legal plases of the doctrine of popular consent up to the time of their writing.

Ronard de Card in Les Amncrions et les plébiscites dans l'histoire contemporaine (Etudes de droit international . .., Paris, I890), and Soliere in the work cited, are less comprehensive in this respect than either Stoerk or Freudentha1, while Borgeaud's study, Histoire du plébiscite... , le plébiscite dans l'antiquité-Grìce et Rome-Genève, I887, confines itself to considerations of the plebiscite as an expression of the popular will in the inner affairs of ancient Rome and Greece.

André David's recent doctoral thesis, Les Plćbiscites et les cessions de territoires, Paris, 1918, contributes to the existing literature chiefly in his last chapter, in which he argues in favor of the return to France of Alsace and Lorraine without the consultation of the population by way of a plebiscite.

E. Wittmann's Past and Prescnt of the Right of $\mathrm{Na}$ tional Self-Detcrmination, translated from the Hungarian by $C$. Biddle, Amsterdan, 1919, conld not be secured in time to be considered for the present study. A perusal of Wittmann's work does, however, show that the author devotes himself primarily to the treatment of the principle of national self-determination as an end in itself, and that the plebiscite as the means towards this end finds only a passing mention.

The following consideration of The Employment of the Plebiscite in the Determination of Sovereignty had its origin in a Seminar paper undertaken in the fall of I9I7 at the instance of Dr. A. C. Millspaugh, who, during Prof. W. W. Willoughby's absence from The Johns Hopkins 
University, was then conducting the courses in Political Science. After Dr. Willoughby's return to academic work, the former study was, at his suggestion and under his encouraging guidance, elaborated and given its present form.

After the manuscript had gone to press, Miss Sarah Wambaugh's Monograph on Plebiscites appeared. This work was "prepared under the supervision of James Brown Scott, Director of the Division of International Law of the Carnegie Endowment for International Peace," and was published by the Oxford University Press, New York, 1920. Its more than a thousand pages contain an historical summary, a detailed account of the plebiscites recorded, and a collection of documents comprising more than two-thirds of the volume.

Miss Wambaugh's book covers in part chapters III-V of the present study. In the matter of historical detail her presentation is more exhaustive than that of the chapters named. The historical side of the question has been treated in the latter, not with the intent of giving a minute description of the precedents cited, but rather with the object of furnishing an analytical basis for the deduction of conclusions and for the technical discussions of the later chapters. The instances of self-determination by assembly vote or by popular suffrage in connection with the American secession movement and the vote in the section of the District of Columbia, retroceded to the State of Virginia, have been omitted from Miss Wambaugh's Monograph. They are, however, included in the following investigations for reasons which will appear from the text.

A number of references to Miss Wambaugh's study have been added to the manuscript where they seemed helpful and convenient. 



\section{THE EMPLOYMENT OF THE PLEBISCITE IN THE DETERMINATION OF SOVEREIGNTY}

\section{CHAPTER I}

\section{INTRODUCTION}

In its common application the term plebiscite is generally used as the equivalent of the principle of popular consent. For practical purposes this is not incorrect. To the popular mind the two terms are indeed identical. However, technically speaking, the principle of popular consent represents an end in itself, the right of the people to decide by simple or larger majority vote matters of government or state, while the term plebiscite denotes merely the mode of expressing or withholding such popular approval of each measure submitted.

Modern authorities define the plebiscite as "a direct vote of the whole of the electors of a state to decide a question of public importance, e. g., a proposed change in the constitution, or the ratification or rejection of a measure approved by the legislature . . . also by extension, a public expression, with or without binding force, of the wishes or opinion of a community." 1 Within the scope of this definition the term is identical with the modern referendum which the same authority describes as "the practice or principle (chiefly associated with the Swiss constitution) of submitting a question at issue to the whole body of voters."'

${ }_{1}^{1}$ J. A. H. Murray, A New English Dictionary, Oxford, 1888-, Plebiscite 2 , Referendum I.

2 Emile de Laveleye in " La démocratie et le régime parlementaire" distinguishes between what Murray defines as the plebiscite and the referendum, referring to the former as "direct legislation by the people, as practiced in the democracies of ancient Greece and 
It is the plebiscite in this narrower sense of the "referendum " that concerns us here-the plebiscite as a popular decision of matters affecting the existence of the state, such as a change of government. peace and war, the acceptance of a constitution and amendments thereto, the transfer of territory, and the like-and not the recurring elections of representatives to legislatures and referenda on similar matters subject to, or growing out of, an accepted policy or practice. Drawing the lines still closer, plebiscites on changes of government. on the question of peace or war, etc., will be considered only in so far as they have been instrumental in popularizing the use of the plebiscite in interstate or international relations and in so far as they have been cited in justification of, and as precedents for, the application of the plebiscite in the transfer of territory.

The plebiscite is thus identified with miversal suffrage, or, at least, universal suffrage is considered as its indispensable attribute. The history of the plebiscite, however, reveals the fact that this view is not supported by actualities, though a growing practice seems to tend in that direction. Only where "the whole of the electors," or "the whole body of voters," terms used in the definitions quoted, imply a direct and unrestricted casting of the ballot, can we speak of a plebiscite by universal suffrage.

The Roman plebiscitum, for instance, originated not as an expression of the will of the entire Roman people but of the plebeian members only.

The reign of oppression and extortion, practiced at the end of the 6 th and the beginning of the 5 th century B. C.

in the Alpine cantons of Switzerland," and to the referendum as "the acceptance or the rejection, by niviversal suffrage, of the laws voted by the cleputies" (Revue des deux mondes, Dec. 15, 1882, vol. liv, p. 47). Borgeaud speaks of a legislative and an executive plebiscite (C. Borgeaud, Histoire du plébiscite, le plébiscite dans lantiquité-Grèce et Rome-Genève, Paris, 1887 , p. xiii). Laveleye's is a distinction of form. Borgeaud's one of content. Francis Lieber distinguislies between the national plebiscite in matters of internal affairs and the international or annexationist plebiscite in internation ${ }_{1}$ relations (Lieber, De la valeur des plébiscites dans le droit international, in Revile de droit international et de législation comparée, I87i, vol. iii, pp. I40-14I). 
by the patricians after the expulsion of the kings, forced the plebeian population to seek ways and means of bettering their political and economic conditions. Assemblies of the plebs and resolutions and decrees, plebiscites passed in these assemblies, were the outcome.

With the creation of the office of the tribuni plebis in the year $494^{3}$ these assemblies seem to have gained official recognition and stability in so far as their convocation was one of the duties and rights of these newly created tribun plebis. Their historical status, however, seems to be somewhat obscure. Borgeaud, after reviewing the prevalent opposing opinions, concludes that the definition of the plebiscitum as a decree enacted in the comitia tributa, the assembly of the Roman tribus, is incorrect. The comitia tributa included, at least after the law of the Twelve Tables was passed, also the patricians, distributed, like the plebeians, among the three local tribus, a view entertained by Niebuhr, Becker-Marquardt, Walter, Blasel, and others. ${ }^{4}$

The Roman jurists, however, are very emphatic and explicit on the one point that the plebiscitum is a decree by the plebeian members of the populace only. Gaius, for instance, defines the plebiscite in a manner which allows of no doubt: "Lex est quod populus iubet atque constituit. Plebiscitum est quod plebs iubet atque constituit. Plebs autem a populo eo distat, quod populi appellatione universi cives significantur, connumeratis etiam patriciis; plebis autem appellatione sine patriciis ceteri cives significantur." In Poste's translation": "A statute is a command and ordinance of the people: a plebiscite is a command and ordinance of the commonalty. The commonalty and the people are thus distinguished: the people are all the citizens, including the patricians; the commonalty are all the citizens, except the

${ }^{3} \mathrm{E}$. Meyer, Der Ursprung des Tribunats, in Hermes, vol. xxx, p. I ff.

${ }^{4}$ Borgeaud, pp. 58-59.

5 Gaius, Institutiones, I, 3.

${ }^{6} \mathrm{Gai}$ Institutiones, or Institutes of Roman Law, with a translation by Edward Poste, 4t'l ed., E. A. Whittuck, Oxford, I904, p. I. 
patricians," or, as Muirhead" renders it: "A lex is a law enacted and established by the whole body of the people; a plebiscite, one cnacted and established by its plebeian members. ..."

On the other hand, Mommsen and his school hold that Rome had, since the time of the decemviri, two kinds of popular assemblies, the comitia tributa, convened by the order of the patrician magistrates and comprising all Roman citizens, and the concilia plebis, called to meet by the tribuni plebis or the aediles. ${ }^{9}$ Borgeand, who adheres to this vicw, explains the difference, or rather the confusion, on this subject by the fact that the concilia plebis are often referred to as the comitia tributa, but only by the historians ${ }^{10}$ and in the popular language, by virtue and in consequence of their political importance, but not in accordance with their juridical nature. ${ }^{11}$ However, uncertain as this matter may be, accepting the definition of the Roman jurists, we can safely state that the plebiscitum was a decree passed in public meeting by the Roman plebeians only.

The Roman plebiscitum then was the result of the attempt made by the Roman plebs to secure for itself a voice in public matters in opposition to the ruling patricians represented by the Senate with its exercise of the auctoritas patrum. It served at the same time as the means for making this voice heard more often and more audibly until finally the Senate, weary of being compelled-by force of popular threats ${ }^{12}$ - to yield to these revolutionary plebiscites, de-

TGaius, The Institutes of Gaius and Rules of Ulpian, with a translation by James Muirhead, Edinburgh, 1880, p. 2.

8 The same distinction is made by Capito and Laelius Felix, cited in Gellius, Noctium Atticarum libri XX, bk. X, 20, 6; bk. XV, 27, I5-25; in the Institutiones Justiniani, I, 2, 4; and elsewhere. Festus defines the Scita plebei as "ea quae pleps suo suffragio sine patribus iussit, plebeio magistratu rogante" (Sexti Pompei Festi De verborum significatu quae supersunt, ed. IV. M. Lindsay, Lipsiae, 1913, Scita plebei).

Borgeaud, pp. 59-6I ; Laelius Felix in Gellius, bk. XV, 27, 15-25.

${ }^{10}$ Livius, Ab urbe condita, bk. II, 58, I ; Cicero, Epist. ad Atticum, IV, 3 .

11 Borgeaud, p. 62.

12 Ibid., pp. 125-128. 
cided by the acceptance of the lex Valeria-Horatia of 449 , to give the plebiscitum the validity of law binding upon all Roman citizens, provided, of course, that the plebiscitum, with the consent of the Senate, was laid before, and adopted by, the comitia centuriata and then given the auctoritas patrum in the Senate. ${ }^{13}$ Thus, after all, it was the post festum ratification by the Senate which made the plebiscite law for all Romans. However, as Borgeaud states, "during this new period in general all the plebiscites obtain the formal, even though more or less bought, adhesion of the Senate." ${ }^{14}$ Thus the plebs, for all practical purposes, succeeded in making its will supreme for all Rome through the enforced sanction of its decisions by the Senate.

Attempts were of course made to check this legislative supremacy of the plebs. A little more than a hundred years after the passage of the lex Valeria-Horatia the reforms of Quintus Publius Philo effected a considerable modification of the power of the plebs in favor of the practically disfranchised patricians. The lex Valeria-Horatia had won for the plebiscitum legal validity for all Romans. The will of the plebs generally secured the auctoritas patrum. The lex Publilia Philonis of 339, still held the plebiscitum to be law for all the Romans, but this law stipulated, so it seems, that the tribuni plebis henceforth must solicit the consent of the Senate (patrum auctoritatem) before they could submit any proposed law to the vote of the plebs. Such at least is the theory entertained by M. Willems ${ }^{15}$ and accepted by Borgeaud. However, in the course of time the plebs refused to abide by this limitation of its acquired prerogatives. If and when the Senate refused its auctoritas in advance to those matters which the plebs wished to do or to have done, the latter did not hesitate to enforce its will

13 "Ut quod tributim plebes iussisset, populum teneret" (Livius, bk. III, 55). See also Madvig, quoted by Borgeaud, p. I30, note I; Willoughby, The Political Theories of the Ancient World, New York, London, I903, pp. 235-236.

14 Borgeaud, p. I32.

15 Ibid., pp. I33-137. 
by means of extra-legal plebiscites. ${ }^{16}$ When, finally, on the eve of the second Samnite war the Senate refused to approve the popular demand, expressed by a plebiscite, for distribution of land and cancellation of debts, the plebs left the city for Mount Janiculus, and the result was that in the same year the lex Hortensia, 287 B. C., was passed, stipulating that "what the plebs ordered should be binding for all Romans." "17

That the Roman plebiscite, even shortly after this method of registering and enforcing the public will had asserted itself, was anything but a mere form was demonstrated by the plebiscitum held on the occasion of the trial of Coriolanus, the patrician, who by this decree of the plebs was banished from Rome for his contempt of, and opposition to, the commons. ${ }^{28}$

With the fall of the Republic the Roman plebs surrendered its hard-fought-for rights to the Emperor and the Senate.

In the fourteenth book of the Odyssey we are told by the hero of the epic that "When Zeus . . . devised at the last that hateful path which loosened the knees of many a man in death, then the people called on me and on renowned Idomeneus to lead the ships to Ilios, nor was there any way whereby to refuse, for the people's voice bore hard upon us." ${ }^{29}$

Proceeding to more historic times we find that in both the Dorian and the Ionian city states, at one time or another, the gradual process or progress from oligarchy and monarchy towards government by the dimos.

In Sparta two centuries of civil strife between the kings and the aristocracy were ended by the laws of Lycurgus, which carried into effect the answer given by the Delphian

16 Ibid., pp. I 40-I 4 I.

${ }_{17}$ "Ut quod ea iussisset, omnes Quirites teneret" (Plinius, Naturalis historia, bk. XVI, Io, I5; Gaius, I, 3).

is Plutarch, Lives, Coriolanus.

19 Homer, The Odyssey ..., done into English prose by S. H. Butcher and A. Lang, 3d cd., New York, Macmillan and Co., XIV, 235-239. 
oracle, commanding Lycurgus to divide the people into phylai and obai, to establish a senate of thirty nembers, to call the Apella from time to time and there to introduce and rescind measures, but to give to the people the deciding voice and power. ${ }^{20}$ Thus "the aristocracy and the kings steeped the city in blood through their quarrels and the constitution of Lycurgus brought them into accord, giving to the Assembly of the people the very power about which they were in dispute." ${ }^{\prime 1}$

However, the people in this Spartan Apella did not record their will and wishes by individual vote but, like the Greeks of Homeric and pre-Homeric times, by acclamation or murmurs. Still, K. O. Müller is of the opinion that "this manner of voting . . . has the merit of indicating in a fashion, sufficiently exact ... not only the number of those who accept and reject, but also the intensity of their will." ${ }^{22}$

In Athens the hereditary kingdom, passing through the stages of government of the aristocracy and tyrants, developed into a pure democracy. "The people, assembled in the agora ... or in the theatre, decided on peace or war, received ambassadors, fixed taxes, disposed of public revenues, appointed and recalled magistrates, ... lodged indictments, granted pardons, in short, it exercised directly all the rights of the sovereign, except one-the making and applying of the laws." 23 Here the process of expressing popular favor or disfavor was that of individual marking of the voting stone, the ostrakon, as described by Plutarch, in his touching story of the plebiscite taken at the occasion of the ostracism of Aristides. ${ }^{24}$

In Sparta the office of the ephoroi, created $757-756$, soon

\footnotetext{
20 Plutarch, Lives, Lycurgus, VI.

21 Borgeaud, pp. 5-8.

22 K. O. Müller, Geschichten Hellenischer Stämme, Breslau, I844, vol. iii, p. 85 .

23 Borgeaud, pp. I3-I4.

24 Plutarch, Lives, Themistocles and Aristides. For details on the plebiscites in Rome and Greece, see Borgeaud. Müller, in the book cited, has traced the democratic movement of more than twenty Doric city states.
} 
became the rival of the Apella as far as poptlar rights were concerned. It did not restrain, but it absorbed the rights of the former and "the ephorate takes thus in Sparta the place which the Assembly of the people preserves to the end in the Athenian democracy." 25

While the decree of the Assembly of the people, together with the formulated code is the source of the written law of Athens, "neither a decree of the Senate nor of the people can supersede the law." "This was the law still in force in 403 after the expulsion of the thirty tyrants by Trasybulus. But, remarks Borgeaud, "wise as it was, such a fundamental distinction between the law and the decree of the sovereign assembly was incompatible with the development of a democracy as absolute as the one which reigned in the country of Cleon. By and by" the 'psephisma' (the decree of the Assembly) came, at least in fact, to take the place of the 'nomos' (the written law') and the will of the sovereign people was to dictate the law of the state; ... this had become the rule in the last century of the independence and under Macedonian hegemony.".2r At that time the law can be defined in the words of Theon: "A law is a decree enacted by the multitude or by an illustrious man in matters of government not for a definite period of time.".28

In Sparta and in Athens the right of the people to vote on matters of government and law had not, as was the case in Rome, been secured by threats and application of force, but rather by the established process of constitutional method and procedure. It was, however, in the Greek city states as well as in Rome the result of a political struggle between the ruled and the ruling.

In Rome the plebiscite was the expression of the will of the plebeian population. It had, after 449, the force of

25 Borgeaud, pp. 9 -I I.

26 Andocides, De mysteriis, 87, 89, cited by Borgeaud, p. 26.

$2 i$ Borgeaud, pp. $26-27$.

28 Theon, Progymnasmata, XIII, $\pi \epsilon \rho l v b \mu v$, I (Rhetores Graeci ex recog. Leon Spengel, Leipzig, 1854, vol. ii, p. I28). 
law for all Roman citizens including the patricians, and, of course, for all non-freemen. Also in the Greek city states the popular vote was limited to one stratum of the population, but here the privilege favored the ruling class as represented by all freemen, for only the latter were entitled to the vote, not the conquered and the natives and their descendants, the perioikoi and the holotes in Sparta and the metoikoi in Athens. To appreciate the significance of this restriction of the unfree, one need only consider that in the year 309 B. C. the population of Attica numbered 21,000 citizens, I0,000 metoikoi and domiciled strangers, and 400,000 heads of slaves. The figures for the citizens and the metoikoi include only the major males. ${ }^{29}$

In the first century of the Christian era Tacitus, describing the land and customs of the Germani, told his fellow Romans that among the German tribes "on affairs of smaller moment, the chiefs consult; on those of greater importance, the whole community, yet with this circumstance, that what is referred to the decision of the people, is first maturely discussed by the chiefs. They assemble, unless upon some sudden emergency, on stated days. . . An inconvenience produced by their liberty is, that they do not all assemble at a stated time, as if it were in obedience to a command; but two or three days are lost in the delays of convening. When they all think fit, they sit down armed. ... Then the king, or chief, and such others as are conspicuous for age, birth, military renown, or eloquence are heard, and gain attention rather from their ability to persuade than their authority to command. If a proposal displease, the assembly reject it by an inarticulate murmur; if it prove agreeable, they clash their javelins. . . ."30 It is to this division of, and balance between, authority that Montesquieu traces the origin of the English free institu-

29 Borgeaud, pp. 7, 174.

30 Tacitus, Germany (The Works ....), Oxford translation, vol. ii. 
tions. ${ }^{31}$ The turbulent times of German migrations and the development of feudalism in the remaining German tribes practically eliminated from their political life those popular gatherings and the assertion of popular approval or censure which had elicited the admiration and marvel of the Roman. 32 Even the "free institutions of England" do not show anything to compare with the plebiscite of the old Romans or Athenians or with the popular deliberation of their German forefathers. "The nearest approach ever made in England to the recognition of an authority eapable of self-expression higher than the ordinary legislature," was the "Agreement of the people" of Cromwell's times, which was, however, not put into operation. ${ }^{33}$

The only spot in Europe where the old gatherings and expressions of popular wishes have not entirely gone out of practice is Switzerland. When, in the fifth century, the Alemanni and Burgundi invaded Celtic-Roman Helvetia,

31 "In perusing the admirable treatise of Tacitus 'On the Manners of the Germans' we find it is from that nation the English have horrowed the idea of their political government'. This beautiful system was invented first in the woods" (Montesquicu, Spirit of Laws, translated by Thomas Nugent, London, I909-I9I4, bk. XI, chap. vi). See also J. M. Vincent, State and Federal Government in Switzerland, Baltimore, I\&gI, p. 4.

${ }^{32 E}$. Mühlbacher, referring to the old practice of the freemen to gather annually in the Maifeld, describes the changed conditions under Charlemagne at the end of the seventh century in the following words: "The great political decisions had long been removed from the influence of the pcople. The old right of the freemen, to appear at the Reichsversammlungen, had not quite become obsolete, but it has become impaired on account of the impossibility for the frecmen to come annually from such large distances. Furthermore, the decisions at these Reichsversammlungen had already for an earlier time rested with the clerical and wordly magnates who, through their position in the administration of the statc and at conrt, or though thcir large possession ... had to a certain degree become the represcntatives of the people. ... Even when the consent of the people was solicited, it was done more as a formality, as a reminiscence of the old time, and it was done only at the occasion of big warlike undertakings which had already been decided upon or had already been commenced..." (Deutsclie Geschichte unter den Karolingern, Stuttgart, I896, p. 261).

$33 \mathrm{~W}$. A. Dumning, A History of Political Theories from Luther to Montesquicu, New York, London, 1916, pp. 238-239. 
they introduced and continued their system of communal self-government with its popular deliberations and decisions of public affairs of importance until the growth of feudalism centered the right and power of making and administering the law in the hands of the feudal lords, the lesser nobles and the clergy. ${ }^{34}$ But with the first signs of reaction against this feudal overlordship, "the communal organism and the municipal spirit were revived and gradually developed in those same localities where they had flourished previous to the feudal period." 35 The progress of this development was, to quote Cherbuliez, "for certain reasons retarded in the western parts and accelerated in the eastern sections of Switzerland, but finally, it led everywhere to the same result. . . The entire community assembles in order to decide questions of weight, in particular in order to sanction all transactions enacted in its name, with individuals or with foreign states. ..."

In some of the rural communities of Uri, Schwyz, Unterwalden, Appenzell, $Z_{\text {ug }}$ and Glarus, "the people have never ceased to legislate for themselves and vote their own taxes from the thirteenth century downwards. They met together, at least once a year, for the purpose in solemn conclave, called the Landsgemeinde." ${ }^{36}$ The first Landsgemeinde of which we have a record is that held in the canton of Schwyz in the year $1294{ }^{37}$

While in practice the ancient principle of poptlar selfdetermination in matters of internal politics disappeared from the life of the nations except in isolated counties of Switzerland, in theory the shibboleth of the sovereignty of the people remained alive through the Middle Ages and was transmitted to modern times in the teachings and writ-

34 Vincent, pp. 4-6; A. E. Cherbuliez, De la démocratie en Suisse, Paris, I843, vol. i, pp. I3-17.

35 Cherbuliez, vol. i, p. 30

36 S. Deploige, The Referendum in Switzerland, translated into English by C. P. Trevelyan, London, New York, 1898, pp. 3-4.

37 J. J. Blumer, Staats und Rechtsgeschichte der schweizerischen Demokratien, St. Gallen, 1850-1859, vol. i, p. 135. 
ings of the poets, the philosophers, and jurists of England, Germany, France, Spain and Italy. ${ }^{38}$

The final evolution of English and American Democracy in theory and practice owes much to writers like Milton and llarrington. Nilton differs from the sixteenth century anti-monarchists in so far as he bases his argument on rational instead of on scriptural support. "All men naturally were born free" and were endowed with right and power of self-defense. "Kings and magistrates, thus, are but the agents of the people; they possess no power save what is originally in every man and is delegated to them, and they exercise no power save under the restriction of the laws." ${ }^{40}$ Harrington believes that govermment must be either "the empire of laws and not of men" or "the empire of men and not of laws." 11 To quote Dunning:

These two conceptions he regards as characteristic respectively of ancient and of modern philosophy, represented typically by Aristotle and Hobbes.... Adopting the idea of the ancients as the sound one, Harrington proceeds to investigate the principles which must underlie a government aiming at the common welfare... Harrington expatiates upon the peculiar importance of the secret ballot, which he conceives to be of the very essence of just popular government. The devices through which he seeks to insure absolute freedom of the voter from all constraint upon his choice are not the least striking of the ideas which bring Harrington in very close tonch with the politics of the nincteenth contury."

It would seem then that Harrington thus leads us back not only to the principle of popular sovereignty of the ancients but also to their method of giving voice and life to this principle by the employment of the plebiscite or referendum with individual expression of the will of the voter. However, this ancient method could no longer be

38 A detailed account of the development of the theory of popular sovercignty is given in Dunning's two books, A History of Political Theories, Ancient and Mediaeval, New York, London, 1916; and A History of Political Theories from Luther to Montesquicu; see also O. Gierke, Political Theorics of the Middle Age, translated by F. W. Maitland, Cambridge, 1913.

39 Dumning, A History of Political Theories from Luther to Montesquicu, p. 242.

40 Ibid.

41 Ibid., p. 249.

42 Ibid., Pp. 249, 252. 
applied with the same simplicity with which it had been worked two thousand or more years ago. The affairs of a modern state were no longer a matter of interest of a single locality or a number of cities. Nor was it still possible to call the "freemen" of a country together at a certain date and place as did the German tribes at the time of which Tacitus wrote. The vote now had to be taken wherever people lived and the results had to be communicated to a central place, the seat of Government, or, according to the system advocated by More in the Utopia, the people had to send their chosen representatives to voice their opinion and will through them and, if necessary, pass final judgment of approval or rejection by popular vote on the decisions reached by their representatives. ${ }^{43}$

It was in France that the modern plebiscite found its first application. Here Bodin, Bossuet, Fénélon, and their adherents, the monarchists, opposed to popular sovereignty, were followed by men like Rousseau, Voltaire, and others who through their writings prepared the way for the reassertion of popular rights-and the culmination of that reassertion in the revolution.

A reference to what may prove to be the earliest record of an application of the principle of the modern referendum or plebiscite in the affairs of state, we have in a letter written to the Comte D'Argental by Voltaire, dated March $3^{\circ}$, I776. Speaking of the "Remonstrance of the province of

43 In his Utopia, in the chapter "Of the Magistrates," Sir Thomas More tells us that "matters of great weight and importance are brought to the election house of the Syphograuntes, who open the matter to their families. And afterwards, when they have consulted among themselves, they show their devise to the counsel" and that "sometimes the matter is brought before the counsel of the whole island." The Agreement framed by the Council of Cromwell's army in 1647 as the basis for an adjustment with the King and Parliament declared itself to be an expression of the will of the people, and made the meaning of the declaration entirely clear by providing that every individual who was included in the people should sign that document (Dunning, A History of Political Theories from Luther to Montesquieu, pp. 238-239). 


\section{Gex," a missive addressed to Louis in 1776 , signed} by "all the citizens of the province of Gex, without exception," in appreciation of the granting of a franchise in amelioration of the conditions complained of, Voltaire says:

I do not believe that the remonstrances of a province "aussi chevite que celle de Gex" could create a great sensation in Paris. I presume that they will worry mighty little about delivering us from leases, servitudes and privileges. But I admit that I would be greatly pleased if the plain and blunt gratitude of a little and almost barbarian country could reach the ear of Sesostris and Sesostra. ... Perhaps some of the adherents of the old feudal government will find our remonstrances too popular. We can answer them that in ancient Rome and even now at Geneva and Basel${ }^{45}$ and in the cantons of Switzerland "ce sont les citoyens qui font les plébiscites, c'cst à dire les lois." 46

The French Revolution proclaimed as the fundamental basis of all government the principle of popular sovereignty. ${ }^{47}$ It gave the French people representative government through its own elected deputies, but the voting system providing for the election of national representatives, de-

44 An agrarian province in the extreme south of France, which in the past had suffered from the oppression and extortion of government officials.

${ }^{45}$ No record of the use of the plebiscite in Basel has been found in the course of this investigation.

${ }_{46}$ Voltaire, Oeuvres complites, Paris, I877-1885, vol. $\mathrm{xxx}$, pp. 34I-344; vol. xlix, pp. 570-57I. Remonstrances to the king by the Parlement de Bretagne, i.e., by the royal court of Brittany, are on record for a considerably earlier time. The text of seventeen has been collected and discussed by A. Le Moy; the first, of January I0, I7I8, the last, of May I2, I789. Le Moy estimates that more than a liundred of such remonstrances, chiefly on the subject of court appeals, finances or economics, and religious matters, had been sent to the court at Paris during the istl century. While these remonstrances were not popular in the sense that they were voted on or signed by the people of Brittany, they are, according to one of them (October 26, 1718), intended "to make the voice of the people pass to the throne" (Remonstrances du Parlement' de Bretagne au XVIII siècle. Textes inédits précédés d'une introduction ... par A. Le Moy, Angers, 1909).

47 Art. 3 of the Declaration of the rights of man and citizen of Ifor reads: "Le principe de toute sonveraineté réside essentiellement dans la nation. Nul corps, nul individu ne peut exercer d'autorité qui n'en émane expressivément" (Arch. parl., ser. I, vol. ix, p. 236). Art. 25 of the revised version of r793 states: "La souveraineté résicle dans le peuple. Elle est une et indivisible, imprescriptible et inaliénable" (Arch. parl., ser. I, vol. lxvii, p. I07). 
partmental and municipal officers, was restricted. ${ }^{48}$ While the Constitution of the year I793 and that of the third year of the Republic were submitted to a vote in primary assemblies, ${ }^{49}$ the decree abolishing the monarchy and establishing the republic was not subjected to popular referendum. ${ }^{50}$

It was in I799 that Napoleon Bonaparte engineered the coup d'ćtat of the I8th brumaire, which replaced the Directoire by the Consulat provisoire. As the Promier Consul he offered to the French nation a new constitution (known as the Constitution of the 22 frimaire of the year VIII, December I3, I799). This new instrument omitted the Declaration of the rights of man and citizen, and did not guarantee the liberty of the press and conscience. It gave the people the right to elect its deputies, to make through them its laws and to regulate its finances. By this new constitution the right to vote was to be given to all citizens, and

48 The election law of Dec. 22, I789, divides the French into passive and active citizens. The former are entitled to all civil rights and protection; only the latter are to take part in the formation of government. "The qualifications required to be active citizens are: (I) to be a Frenchman; (2) to have completed the 25 th year of age; (3) to be actually domiciled in the canton, or at least for a year; (4) to pay a direct contribution equivalent to the local value of three days of labor; (5) not to be in the condition of a domestic, that is, not to be a paid servant." For a detailed description of the history of the law and its actual application see F. V. A. Aulard, Histoire politique de la révolution française, Paris, I90I, pp. 6o-8o.

49 The adoption by the National Convention of the Constitution of June 24, 1793, was followed by a decree regulating the system of the voting in the primary assemblies to which the Constitution was to be submitted for popular acceptance or rejection (Archives parlamentaires de 1787 à 1860 , Recueil complet des débats législatifs et politiques des chambres françaises, ser. I, vol. 1xvii, pp. 367-368). The Constitution of the year III (Aug. 22, 1795) was adopted by a primary assembly vote of 914,853 against 4I,892 (Larousse, Grand dictionaire universel du XIX ${ }^{\mathrm{e}}$ siècle, Constitution). The first French revolutionary constitution of Sept. 3, I79I, was adopted in the $\mathrm{Na}$ tional Assembly and offered by order of the Assembly to the king for acceptance. On Sept. I4, Louis XVI rendered the oath on the constitution in the Assembly (Arch. parl., ser. I, vol. xxx, pp. I89I90, 635).

50 This decree was passed in the National Convention on Sept. 2I, 1792. On the same day the Convention ordered the verbatim report of the meeting to be sent to the departments and to the armies. It was ordered further that "the decree pronouncing the abolition of the kingdom be solemnly proclaimed in Paris tomorrow and in all municipalities the day after its receipt" (Arch. parl., ser. I, vol. lii, p. 74). 
citizens were to be "all Irenchmen, twenty years of age and domiciled for one year, except paid domestics." ${ }^{1}$

The system under which the vote was taken on this new constitution admitted all citizens, but they were forced to record their vote in public. By the Law of the 23 frimaire it was decreed that in each commune public registers were to be opened, one for acceptance and another for non-acceptance. Each citizen had to enter in person his "yes" in the register d'acception, or his "no" in the register de non-acception." When the date set for the voting arrived Napoleon found a way to extend the time over nearly two months, and by another coup d'ctat, in the midst of the voting (by the Law of the 3 niwose) placed in operation the very same constitution whose acceptance or rejection was subject to the vote which was not concluded until the end of the same month. ${ }^{53}$ The "yeas" counted 3,OII,OO7, the "nays" I,562. ${ }^{54}$

Aulard refers to this plebiscite as the one which brought the term "le suffrage miversel" into usage. He cites Mallet du Pan, writing in London on the Constitution of the year VIII, as the first to use the term when he applied it in the Mcrcure britannique of January, 1800 , and he judges that it was Mallet who introduced the term "universal suffrage" into English political phraseologr..$^{5 \pi}$

With this successful rote on the constitution there began in France the era of the plebiscites, or, as Aulard expresses it. "thus was founded in France the Rípublique plébiscitaire."

In the year $\mathrm{X}$ of the Republic ( 1802 ) another plebiscite by $o u i$ and non was held. Out of a total of 3.577,259 not less than $3,568,885$ citizens voted in favor of making Napoleon Bonaparte consul for life. ${ }^{5 i}$

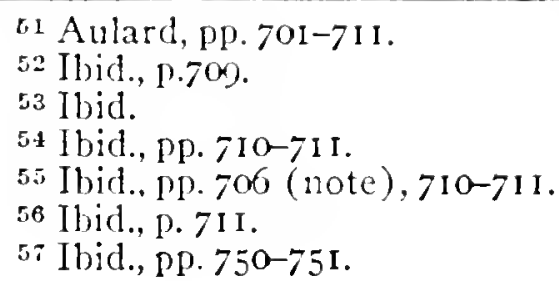


The sénatus-eonsulte of the 28 floréal of the year XII (May I8, I804) provided that "le gouvernement de la république est confié à un empéreur, qui prend le titre d'emperreur des Français" and that "Napoléon Bonaparte, premier consul de la république, est empéreur des Français." The same decree provided for the heredity of the new dynasty. By popular vote the decision of the Senate was confirmed. "Out of 3,524,254 electors who registered their votes in the books prepared for this purpose, 3,521,675 voted in favour of the proposal which called Napoleon to the imperial throne. There were only 2,579 opponents."58

From 1848 to 1852 France was the scene of three plebiscites, which, in their consequences, made Napoleon Emperor of the French and which, on account of their results rather than their conduct, have served more than any other to create for the plebiscite a place in European state and interstate affairs.

By popular vote Louis Napoleon was elected President of the French Republic in $1848 .^{60}$ The plebiscite of December 20 , I85I, declared that "they [the people] want the maintenance of the authority of Louis Napoleon, ... " " 61 and by referendum of November, 2I, 1852, the French people confirmed the sénatus-consulte conferring the hereditary title of emperor upon Napoleon. ${ }^{62}$

58 Quoted by Aulard, p. 776.

${ }^{59}$ C. F. de Méneval, Memoirs Illustrating the History of Napolean I from I802 to I8I5, New York, I894, vol. i, p. 285.

${ }^{60} \mathrm{P}$. La Gorce, Histoire du second empire, Ioth ed., Paris, I908, vol. i, p. 3; Histoire de la seconde République française, 5 th ed., Paris, I909, vol. ii, p. 2.

${ }_{61} \mathrm{La}$ Gorce, Histoire du second empire, vol. i, p. I2.

62 Ibid., pp. I00-I02. 


\section{CHAPTER II}

\section{Time Plemiscite in Ancient and Feudal Times}

When a territory is transferred from the sovereignty of one state to that of another, the consent of the inhabitants of the territory thus affected is required to make the transfer valid. Such is in essence and extent the doctrine of popular consent, commonly called the right of self-determination or self-definition. ${ }^{1}$

Under the existing rules of international law, the inhabitants of the territory ceded cease to be subjects or citizens of the ceding state and become, or are forced to become, sooner or later, subjects or citizens of the acquiring state. ${ }^{2}$ It is this enforced change of the personal relation to the states involved, rather than the change of the state's sovereignty over the territory itself which provicles the incentive to, and the justification for, the demand that the voice of the people be heard when such territorial changes are effected. ${ }^{3}$

\footnotetext{
1 See note 3 .

2 "As the object of cession is sovereignty over the ceded territory, all such individuals domiciled thereon as are subjects of the ceding State become ipso facto by the cession subject's of the acquiring State" (L. Oppenheim, International Law, 2nd ed., New York, 1912, vol. i, p. 289). See also A. Rivier, Principes du droit des gens, Paris, I8g6, vol. i, p. 204. The privilege of option, a more recent development, permitting inhabitants to choose between the acceptance of the new and the retention of the old citizenship, will be discussed later.

3 "The hardship involved in the fact that in all cases of cession the inhabitants of the territory lose their old citizenship and are handed over to a new Sovereign whether they like it or not, has created a movement in favour of the claim that no cession shall be valid until the inluabitants have by a plebiscite given their consent to the cession. ..." (Oppenheim, vol.i. pp. 280-29o.) The same view prevaits among American writers on international law. In American Insurance Co. v. Canter, the United States Supreme Court states that "the same act which transferred their territory transferred the allegiance of those who remain in it," and in Boyd v. Thayer the
} 
Modern international law sanctions the transfer of territory from one state to another under the following forms: by succession, by conventional exchange or sale, by voluntary cession or cession enforced by treaty of peace (after conquest), by lease ${ }^{4}$ and, recently, also, by pledge. ${ }^{5}$

Territorial changes by succession were chiefly responsible for the formation of the great European nations, partly also for the dismemberment of others. They were as a rule conditioned by dynastic family pacts but they are "no longer possible for those peoples who concede the principle that sovereignty resides in the nation." 6

Exchanges of territory between states, usually known as frontier rectifications or determinations, as a rule cover small areas, but the territories exchanged are sometimes of considerable size, as was, for instance, the part of Bessarabia which Rumania, by the Treaty of Berlin in 1878 , was forced to exchange with Russia for the islands at the conflux of the Danube, the Sandjak of Toultcha and a strip of the Dobrudja. ${ }^{7}$

Territorial changes by sale are too numerous to be cited here; suffice it to mention the purchase by the United States of Louisiana, and of the Danish West Indies. ${ }^{8}$

Voluntary cessions have been equally frequent in the past. ${ }^{\circ}$ However, the old maxim that "the sovereign held eminent domain over the soil, that the inhabitant was the subject of the sovereign and that the sovereign had legally the power to dispose freely of the soil and the inhabitant ${ }_{10}$

court declared that "the nationality of the inhabitants of territory acquired by conquest or cession becomes that of the government under whose dominion they pass, subject to the right of election on their part to retain their former nationality by removal or otherwise as may be provided" (Willoughby, The Constitutional Law of the United States, New York, I9Io, vol. i, pp. 443-444).

$4 \mathrm{H}$. Bonfils, Manuel de droit international public, 3 rd ed., Paris, I901, nos. 564-569, 571'.

5 Oppenheim, vol. i, p. 27 I.

6 Bonfils, no. 564 .

7 E. Hertslet, The Map of Europe by Treaty ... since the General Peace of I8I4, London, I875-9I, vol. iv, p. 2791.

8 Extended list given by Bonfils, 110. 5.66 .

9 Bonfils, no. 567 .

${ }^{10} \mathrm{~T}$. Funck-Brentano, and A. Sorel, Précis du droit des gens, 3 rd ed., Paris, I900, p. 156. 
has, uncer the influence of the principles proclaimed in the French Revolution, been modified to the effect that today the nation is recognized as an essential part of the state and that the nation is the carrier of sovereignty. ${ }^{11}$

Voluntary cessions are those transfers of territory which are effected without the use of force by one of the contracting states. More frequently, however, territorial transfers are the price of a peace forced by one state tpon the other and are preceded by war and the ensuing conquest and military occupation of the territory ceded, as was the case of the cession of Lombardy by Austria to France in I859, of Alsace-Lorraine by France to Germany in $187 \mathrm{I}$, of Cuba, Porto Rico, the Philippines, the Island of Guam by Spain to the United States in I $898 .{ }^{12}$

Territorial changes by leases are ustrally stipulated to be for a certain number (99) of years, but for all practical purposes they are considered as final. China leased Kiaochat to Germany, Port Arthur to Russia and Wei-Hai-Wei to Great Britain. ${ }^{13}$

Transfers by pledge are those which are to take effect at a later, a fixed date or after certain conditions have been or have not been fulfilled. The Republic of Genoa pledged Corsica to France in 1768 , Sweden pledged Wismar to Mecklenburg in $1803 .{ }^{14}$

Technically speaking, all these forms are territorial clanges known in international law as cessions. With the exception of the transfer by lease all involve the immediate or eventual change of allegiance of the inhabitants of the territories thus ceded or transferred and to all therefore

11 Bonfils, no. 567 . It is on the strength of this view that most of the French publicists favor the plebiscite in the transfer of territory. But among the opponents of the principle of popular selfdetermination as the means of territorial settlements, chiefly German, English and American writers, we find also French dissenting opinion. Rivier, for instances, states that: "The theory of the plebiscite is attached to the ill-comprehended dogma of popular sovercignty and to the principle of nationalism; it is for this reason it could play a role in France and Italy" (p. 21 i ; Bonfils, no. 570).

12 Bonfils, nos. 564-569, 57 $\mathrm{I}^{1}$; Oppenheim, vol. i, pp. 270-27I.

13 Bonfils, no. $57 \mathrm{I}^{1}$; Oppenheim, vol. i, p. $27 \mathrm{I}$.

14 Oppenheim, vol. i, p. $27 \mathrm{r}$. 
the modern demand for popular consent or self-determination may be extended.

The diplomatic study of the historical cessions of the past reveals the fact that the principle of popular consent has in some form or other been applied chiefly in cases of territorial transfers by what we have called voluntary cession, enforced cession, and, in some cases, in transfers by sale.

While ancient Rome and Greece practiced the plebiscite or referendum in their internal affairs and thus recognized the principle of self-determination as applied to themselves in their doings at home, in matters of foreign relations, in their relations to their neighbors, they recognized no other rights than those of their own will and power. All other nations were deemed barbarians who were to be left alone when strong but were to be conquered and enslaved when weak. The German publicist Rotteck writes:

From the oldest times up to the present and almost everywhere and always peoples have been forced to let themselves be treated like cattle, to be sold like common merchandise, to be exchanged, pawned, given away, to be offered in payment, to be stolen, distributed, to be inherited according to civil law ... and to be thrown in as dowry of marrying women. ... That such should have happened in ancient times should not prove strange, since in those early times there existed hardly any conceptions, or at least only dark ideas, of law, especially of international law.... The powerful rulers of the far-reaching territories of the East and the little tyrants of the West considered themselves the unrestricted proprietors of their lands and of all that they included, peoples no less than real property.... When they warred among each other, the loser was deprived of all or part of his territory. . . . The peoples which were thus transferred from one rule to another were not consulted. ... They did not really become members of the new state . . but they remained booty of war, property subject to the 'Sachenrecht.'

Even when Republics made conquests... this was done solely on the basis of Sachenrecht. Political right, citizenship proper remained exclusively with the conquering tribe. . . Thus it was with the Greek republics, ... thus it was with the world ruler-Romewhich of the subjugated lands and peoples accepted only those of Italian soil into the relation of allies and very much later into citizenship, while she treated all the rest under the name of provinces as subject to Sachenrecht.

During the storms of the migrations... brute force reigned supreme. Later, after the growth of feudalism even the small national ties were torn. Of former peoples nothing but greater or 
smaller groups were left, ... absolute property of their masters, ... inheritable chattle of the manor. ${ }^{15}$

Thus we seek in vain for anything that might be construed as a precedent for the application of the principle of popular consent in the practical international relations of those early states and peoples who, in the inner affairs of their political life, were the most jealous of popular rights and prerogatives, at least as far as they, as freemen or citizens, were concerned.

The earliest recorded manifestations of popular consent or refusal in the case of the transfer of sovereignty or allegiance we find in France.

Solière enumerates as plebiscites a number of cases where peoples, by public expression, give or withhold their consent to changes of allegiance proposed by their feudal lords, or choose or reject a new lord by the assertion of their own will. The cases cited belong to a time when feudalism in France had long ceased to be in its prime, but they are supposedly based on what Solière calls the droit féodal, or the ancicn droit. "We do not fear to affirm," he writes, "that in the Ifth contury and at the beginning of the I $\mathrm{j}_{\text {th }}$ century, it is a rule generally enough admitted, that no annexation can be pronounced without the assent of the people or the notables." And in the last chapter he says: "it is a rule generally admitted and founded on the principles of the droit ancien, that in the $\mathrm{I} 2 \mathrm{th}$ and $\mathrm{I} 3^{\text {th }}$ centuries no annexation can be pronounced without the assent of the people and the notables."16

Solière does not, in substantiation of his affirmation, adduce documentary evidence for any case prior to the middle of the $13^{\text {th }}$ century.

In the chapter on the duties of the seigneur, Achille Luchaire quotes Fulbert de Chartres and the Etablissemonts

${ }_{15} \mathrm{~K}$. W. R. von Rotteck, Das Staats-Lexikon. Encyklopädie der sämmtlichen Staatswissenschaften für alle Stände, hrsg. von Carl von Rotteck und Carl Welcker, Altona, 1845-1848, Rotteck, Abtretung.

${ }_{16}$ E. Solière, Le plébiscite dans l'annexion, Paris, 1901, pp. 7, I56. 
de St. Louis to the effect that the rights and duties of seigneur and vassal are reciprocal and are based on contractual relations, whether the contract "exist in the form of an authentic charter or merely is supposed to exist as the result of a situation dating from time immemorial." Luchaire continues:

The feudal situation, resulting from a tie which unites the suzerain and the vassal, cannot be modified except by the consent of both parties, [and] just as the vassal has not the right to alienate the fief without the consent of the suzerain ... thus the suzerain would be lacking in his duties if he would alienate the fief or the seigneurie without the agreement of his vassals. . . The vassals are thus considered as having a real right over the seigneurie of which they form a part. The seigneur cannot dispose of their allegiance [hommage] in favor of his creature. ${ }^{17}$

It must then be admitted that during the prime of feudalism no transfer of feudal territory could be made without the consent of the vassals. A number of cases where the vassals made actual use of their right of consent or refusal in such changes during the eleventh century are given by Molinier in his Administration féodale dans le Languedoc. ${ }^{18}$ The admission, however, does not concede Solière's claim, that "in the I2th and I 3 th centuries no annexation can be pronounced without the assent of the people and the notables." Feudal society consisted of more categories than seigneur and vassal.

To make matters clear we have to consider the feudal politico-social system a little more closely. Let us move down from the top: the king is the suserain of both the grands seigneurs and the smaller vassals. The grands seigneurs, or grands vassaux, are the holders of the seigneuries, the great fiefs. These grands vassanx in turn have around or under them a host of smaller vassals who have received from them their smaller fiefs for personal services rendered in the past or to be rendered in the future and hold them as personal gifts. Above their feudal attachment to their seigneur these smaller vassals owe at the same time

${ }^{17}$ A. Luchaire, Manuel des institutions françaises. Période des Capétiens directs, Paris, I892, pp. 214-218.

${ }_{18}$ Cited by Luchaire, p. 217 , note 2 . 
allegiance to the king, as the suzerain of both seigneur and vassal. ${ }^{1 "}$ The territorial arrangement was as follows:

Each seigneur possessed a certain number of rights which he exercised, within the limits of a territory more or less extended, over diverse elasses of people. The territory of a seigneurie... was ordinarily composed of three categories of lands: the one the seigneur inhabited with his family and his men [gens], comprising his château and his diverse residences, with dependencies and houses, gardens ... forming the propriétés seigneuriales; the second which were occupied by his urban and rural tenants, whose direct administration he had reserved to himself. These formed his domain proper. And the last whose enjoyment and droits utiles he had conceded to his vassals, under obligation of hommage and noble service; these formed his fiefs, feoda. In each of these categories of lands there were nobles, men of the church, bourgeois and villains, serfs and other mainmortables. ${ }^{20}$

J. Flach describes the state of society in the formative stages of feudalism as one of violent instability and he speaks of the mightiest man as "the one who has a numerous fighting force [hommes d'armes], retreats [castclla] secure in case of alarm": who will "attract soldiers to his clientele [rassalité], peasants into his dependence [potestas], villages into his tutelage [commandise].".1 We have here a clear characterization of the vassal as the soldier, the fighting man, as distinguished from the peasant, the dependent and the villager. Considering now Solière's statement that "peoples and notabies" had to be considered in every case of a transfer we find his term people decidedly too wide and too indefinite. It may be objected that Solière limits his statement to the 12 th and $13^{\text {th }}$ centuries and that during this time "the people" actually were consulted.

E. Glasson, describing the system of alienation of the fief, distinguishes two periods with differing modes of alienation. He writes:

19 In a letter to one of his vassals Fulbert de Chartres, in the beginning of the eleventh century, admonishes the addressee thus: "I exact from you the security of my life, of my limbs and of the land I possess. ... I count at the same time on your aid against any person in the world, except against King Robert" (cited by Luchaire, p. 192).

${ }^{20} \mathrm{La}$ Grande encyclopédie illustrée, Féodalité, régime politique.

$21 \mathrm{~J}$. Flach, Les origines de l'ancienne France, $\mathrm{X}^{\bullet}$ et $\mathrm{XI}{ }^{\circ}$ sjècles, Paris, 1886-1904, vol. i, pp. 128-129. 
During a first period the vassal, wishing to remit his fief to another, had to remit it into the hands of his seigneur with the request that the seigneur invest with it the person to whom the vassal wished to present it. In fact the fief was inalienable and this was a natural consequence of its original character: the seigneur had conceded the property by reason of certain personal services which the vassal should render him and any mutation would have modified the situation. ... Such was the ordinary mode of the transmission of fiefs during the gth and roth centuries. This process has fallen into desuetude, but it was never abrogated and one need not be astonished to meet it sometimes in the texts of a later epoch. During a second period the formalism was suppressed and the vassal himself directly transmitted his fief, but with the consent of his seigneur. This second period seemed to open with the IIth century. The seigneur limits himself to give his consent to the alienation, but he is careful to secure payment for his consent. Thence dates the right of sale which already appears in the patents of the IIth century. A great number of texts speak of the necessity of the consent of the seigneur in almost all parts of France. ${ }^{22}$

Glasson does not mention the question of the consent by the people of the fief thus transferred by the vassal, the villagers, bourgeois, and the serfs and others. Luchaire refers to one case in the 12 th century where, in 1127 , in the election of a successor to Count Charles le Bon of Flanders, "one sees participate not only the "hauts barons flammands,' but even the bourgeois of the large cities, Gand and Bruges. ..."23 However, the bourgeois were not the people. "The totality of those enjoying the benefit of the franchise constitute the body of the bourgeois. . . The conditions required to be a bourgeois of a free city are nearly the same from one end of the territory to the other. ... The population of a free city does not always coincide exactly with the body of the bourgeoisie. There remain ordinarily outside $(a)$ the agents of the seigneur . . , (b) the noblesse and the local clergy ...., (c) the strangers, properly called... and certain inferior categories, $(d)$ the subjects of the seigneurs who have not been conceded the franchise. ...",

Solière's repeated statement we would therefore modify to the extent of holding that during the 12 th and I $3^{\text {th }}$ cen-

${ }^{22}$ E. Glasson, Histoire du droit et des institutions de la France, Paris, 1903, vol. iv, pp. 326-327.

23 Luchaire, p. 218 , note I.

24 Ibid., pp. 390-391. 
turies no peaceful alienation of fiefs by the seignem conld be pronounced without the consent of the vassals and that in some cases the bourgeois asserted the right of choosing their own liege lort.

However, such consent cannot be construed as a concession or assumption of popular rights in the nodern conception. The relations between seignenr and vassal were of a personal character, based on the need of mutual protection. As Flach expresses it, "to attach hearts was in this period of unbridled violence the essential point. It was the surest, in truth, the only way, to be assisted, supported and protected. ..."25 Fulbert de Chartres has formulated the relations of vassal and lord in the year $1020 .{ }^{26}$ The duties of the rassal he divides into negative and positive obligations. He must do nothing to harm the life and estate of his liege lord, and he must protect his life and estate. "However the ford in all his relations must give to his vassal the same in return." "Dominus quoque fideli suo in his onmibus vicem reddere debet." Hence the lord conceded to his vassal the right of consent or refusal to a change of feudal allegiance, but he did concede it as a measure of prudence and self-protection. For a vassal forced to an unwilling allegiance was a poor protection and a doubtful security for the new lord and the changes of allegiance were indeed many. As Luchaire remarks, "feudal France, from the point of view of territorial conditions, has been something essentially moving and floating [flottant]..." "In almost all regions of France the order of tenures or dependence [des mouvances] has varied not only from period to period... but also considerable changes have taken place during each period, sometimes from one year to another.",

The same argument holds good for the valuation of the concession to the bourgeoisie of consent or refusal in matters of choice of feudal homage or allegiance to the king.

\footnotetext{
25 Flach, vol. ii, p. 518.

26 Ibid., quoted, vol. ii, pp. 518-519.

$2 \pi$ Luchaire, p. $22 \mathrm{I}$.
} 
This concession on the part of the seigneur was no more a recognition of popular or democratic rights than was the contractual right of consent or refusal of the vassal. With the growth of the extent of the cities and the increase of the enfranchised men and women of these growing centers of habitation the question of contentment or discord, of attachment or hostility to the seigneur came to be a most vital one. Expressed voluntary allegiance afforded a greater sense of security to the seigneur than an enforced and resented submission, especially in the turbulent times of the formative and declining period of feudal times.

In the relations of bourgeoisie and king this concession of consent or refusal was a welcome means of enlarging royal suzerainty and sovereignty, in fact it was the chief means by which the king finally emerged triumphant out of the struggle with his more or less independent feudal lords. ${ }^{28}$

This class, intermediary between the villains and the seigneurs of the fiefs, did not achieve all its importance until the end of the reign of Louis le Gros and the erection of the communes. . . . Aided in the I2th century by the kings, who protected it against the feudal lords and granted it charters, in turn it obligated them by the sacrifice of blood and money at Bouvines, Taillebourg, Mons-en-Puelle. ${ }^{29}$

Finally-and above all-of the people in feudal society of the 12 th and $13^{\text {th }}$ centuries, the bourgeoisie represented a decidedly privileged class.

Upon examination the cases cited by Solière fail to support his theory even for the time after the I 3 th century.

The earliest case is that of the secession of the Lyonnais from the Holy Roman Empire and its accession to France in I 307 .

At the end of the twelfth century the Lyonnais had secured its independence from the Empire. ${ }^{30}$ To escape the domination of the Church "the citizens of Lyons pro-

${ }^{28}$ Ibid., pp. 221, 391-392.

${ }^{29} \mathrm{Ch}$. Dezobry and Th. Bachelet, Dictionnaire général de biographie et d'histoire, Bourgeoisie.

${ }_{30}$ "Lyonnais, grand gouvernement of ancient France, consisted of three provinces: the Lyonnais proper, Forez and Beaujolais. ... Under the Romans this country formed part of the first Lyonnaise. It came afterwards under the domination of the Burgundians (413), 
clained thenselves subjects of the Fing of France and asked him to take them under his special care."31 The Treaty of Pointoise of 1307 between the king and the Church of Lyons finally established French sovereignty over Lyons. By royal aet the text of the treaty was read and explained by the notary Cherubin de Prinn to the people of Lyons. From November 30 to the end of December he proceded from village to village, calling together "by the ringing of church bells and the sounding of the rustic horn" ${ }_{32}$ the majority of " the inhabitants and nobles," submitting to them the pact in their own vulgar language and, so Solière states, " no document relates any refusal of approbation."

According to Solière the treaty itself did not recognize the right of the citizens of Lyons to be heard in the transfer of their city to French allegiance. It was only "at the last moment that the king betook himself to reflect that the matters touched in the treaty concerned the Lyonnais rather closely."34 Then by a new act it was ordered that the Lyonnais be consulted, and only then was the decision reached to "heed their objections [ríclamations], if such will be justified, or well-founded [s'il y al licu]." Solière

then under that of the Franks (534), was assigned by the Treaty of Verdun (846) to Lothaire. . . and later came to be one of the possessions of Charles le Chanve (869). In 955 the King of Burgundy had the Lyonnais ceded to him by King Lothaire. Having become independent .... the country was possessed by the Counts of Forez. The German Emperor Frederic I ceded his rights over Lyon and the Lyonnais to the archbishop of Lyon and his Chapter. King Philippe Auguste [of France] ratified this cession in I 83 " (Laronsse, Grand Dictionnaire universel di XIX siècle, Lyonnais).

31 Soliere, pp. 10-II. "In the middle ages Lyon was successively a part of the kingdom of the Burgundians, of the empire of Charlemagne, the kingdom of Lothaire; finally, in 879 , of the kingdom of the Provence. ... Owing to the troubles which marked the end of feudalism, the temporal power slipped from the house of Bourgogne... (1032), and came to rest, despite the protests of the connts of the Lyonnais and of Forez, in the hands of the archbishops (1173). But owing to the appeal of the citizens of Lyon [bourgoisie lyonnaise] to Philippe IV, they [the archbishons] had to share their sovereignty with the King of France (1274)" (Nouveau Larousse illustré, Lyon). This section seems to suggest that in I274 a popular demonstration occurred, similar to, or identical with, the one hepe cited by Solière.

32 Solière, pp. 10-13.

33 Ibid.

34 Ibid. 
attributes this belated and sudden consideration for the Lyonnais on the part of the king to the influence of the church dignitaries of Lyons. The Chapter "knew how to persuade the king that it would be better first to conclude the treaty and then to make it valid by [the consent of] the Lyonnais." ${ }_{35}$ Solière does not search after the motives for this attempt at persuasion.

Considering the facts in the case, as presented by Solière, we may venture to offer the following in explanation: The citizens of Lyons had acclaimed the King of France as their sovereign. In case they had been consulted in the making of the treaty they would, most likely, have agreed to its stipulations. Hence it was unnecessary to consult them. The citizens of the Lyonnais outside of the city, in the villages, had apparently not yet expressed any desire for annexation to France. If consulted during the making of the treaty they, however, might have done so. On the other hand, if afterward confronted with the established fact of transfer without their pre-solicited consent they might, in a mood of resentment, raise those objections which the king, in the treaty, actually promised to respect, or ordered to be respected, in case they would be justified. It was this possibility which might have given the Chapter a new lease on its escaping prey. As things turned out, "no document relates any refusal of the approbation" of the treaty. Another reason for the action of the Chapter of Lyons might have been that it wished first to secure the kind of bargain it desired with the king himself, and then afterward would solicit, as a matter of form, the assent of the people concerned so as to allay the unrest and strife which had forced the intervention on the part of the king in favor of the Lyonnais against the political assumptions of the Church.

Solière refers in this case to the citizens of Lyons, and to the inhabitants and the nobles of the Lyonnais. In the light of the facts given in the exposition of feudal society the citizens of Lyons, or even of the Lyonnais, including the villages and the surrounding country, were the bourgeois.

${ }^{35}$ Ibid. 
The sane can and must be said of the "inhabitants" who, with the nobles, were called together by the ringing of the church bells and the sounding of the rustic horn. Soliere himself adnits they were called together to have explained to them that "an agreement had been effected between the Church and the king, but that the approbation of the agreement by the Lyonnais was awaited in order to have it executed." Serfs and other non-enfranchised inhabitants of the Lyonnais could not give nor would they be asked to give their approbation to an agreement between the Church and the king, ${ }^{36}$ unless by special privilege granted by the Cluurch or the king. The case as presented by Solière, however, does not justify the assumption of such privileges. We accept then the term inhabitants, used by Solière, as equivalent to bourgeois.

From a Latin letter written to Alphonse de Poitiers et Toulouse, the son of Louis IX, then King of France, by Thibaut d'Etampes, Alphonse's chaplain, we learn that the people of Marseilles, in public gathering (in parlamento vocato), offered their city to the House of Toulouse by acclamation of those present. The letter as cited by Solière reads :

And so about the affair concerning Marseilles in regard to which you have requested me to talk anew with Rostano de Alto Podio and Guilelmo de Castro. I was told by magister P. de Vincenobrio what he had discussed with them in secret; and they told magister P. under oath that they themselves had been present in Marseilles, when in the presence of R., of good memory, the former comes, your predecessor, and the greater part of the magnates and the plebeians of the city [plebeium ciritatis], ${ }^{37}$ there arose one from the city and said, in the convention called [in parlamento vocato]: "we have given our city of Marseilles for life to the comes and the written instruments have thus been made out." And after that there arose another and said, in the presence of the comes and his own and the people [populo]: "the comes has done us the greatest good and honor, let us give to him and to his heirs our city in perpetuity:" and then began the people to cry "Sye, Sye, Sye," which, in the vulgar language, means "it be, we wish it, it pleases us." And in such manner was this expression [verbum] divulged and exclaimed that there was no other word heard in public. ${ }^{38}$

\footnotetext{
36 Ihid.

${ }^{37}$ Civitas, urbs episcopalis ( $\mathrm{Du}$ Cange, Glossarium mediae et infimae latinitatis, Civitas).

${ }^{38}$ Solière, pp. 13-14.
} 
We have here again the contradistinction of people and nobles in the terms plebes and magnates. The plural plebes is used in mediaeval Latin in the meaning of fideles, qui Episcopo vel Sacerdoti proprio subsunt ${ }^{39}$ - the faithful under their Bishop, or their own priest. ${ }^{40}$

In the year I214 la ville basse of Marseilles recovered its independence from the counts of the Provence and constituted itself a republic. La ville haute remained in submission to the bishops and was erected into an episcopal fief by them. ${ }^{41}$ Furthermore, the author of the letter, using the term plebium, was chaplain to the son of the King of France, and as an ecclesiastic ${ }^{42}$ was likely to refer to the inhabitants of Marseilles, an Episcopal city (civitas), ${ }^{43}$ as fideles, or faithful. Using, as he does, the two terms magnates and plebes in juxtaposition, his use of the word plebes must, however, imply more than ecclesiastical notation. It seems safe to state that the plebes, as here referred to, are the bourgeoisie.

The assertion on the part of the plebes and magnates of Marseilles in favor of the House of Toulouse lacks the aspect of spontaneity which a genuine case of self-determination should exhibit. Aside from the indication of intrigue suggested by the secrecy spoken of by the writer of the letter, the text of the document clearly proves the motive for the assertion. "The comes has done us the greatest good and honor, let us give to him and to his heirs our city in perpetuity. . .." But even the House of Toulouse could not continue to do the greatest good, for in the following year Charles d'Anjou, after a war of eight months, made himself master of the city ${ }^{44}$ and apparently without the consent of the plebs and magnates.

\footnotetext{
${ }^{39}$ Du Cange, Plebes.

40 Parochus proprius, le curé propre (Luchaire, p. 4).

41 Larousse, Grand dictionnaire universel, Marseille.

42 "Les chapelains, les officiers ecclésiastiques de la maison du roi et des princes, qui servent à leurs chapelles" (Littré, Dictionnaire de la langue française, Chapelain).

43 See note 34.

44 La rousse, Marseille.
} 
The case of the people of Paniers, agreeing by acclamation to the change of overlordship in 1285 , assumes a very different aspect from that shown in Solière's presentation if we consider in their entirety the sources quoted and referred to. Solière states:

In 1285 Plilippe le Hardi, having invaded Roussillon, traversed the Pyrenees and besieged Gerone, saw his army decimated by fever and warfare. It could not retire save by the aid of Roger Bernard, Count of Foix. To show his gratitude to the latter, Philippe ceded to him by diverse charters his rights over Pamiers. In order that the seigneurie of Pamiers be well-assured him, Roger Bernard hastened to present his credentials to the consuls. ${ }^{45}$ The people convened in the public place, consented by acclamation to agree with him.

Solière then quotes part of the approbatio concessionis ... per consules et universitatem ville Appamie, which, in its essentials, may be given as follows: "And there the said lord, the count, asked and inquired of the said people [hominibus] of the said city, whether they consented to the agreement and pact... And the people answering together, or the greater part of them, said at the same time [pluries] with a loud voice 'thus, thus we will it, we will it." But the same source continues: "and the said lord, the comes, in turn replied to the said people and the aforesaid city [universitati] and said that he himself wished always to have harmony and agreement with them and that at the present [in presenti] consented to this understanding and agreement." Would it be saying too much to assert that the mutual assurances between the people and the new lord resembled more the contractual relations and agreements of the feudal lord and his vassals than the free choice of allegiance in the sense in which we are wont to speak of it today? A further examination of the same source referred to by Solière shows that owing to the opposition of Bernard Saisset, the Abbe de Saint Antonin, the mutual agreement of people and lord was of no avail.

A royal patent, approving the transfer of Pamiers from

45 Consul, administrateur d'une ville libre dans le midi et le centre de la France, officier féodal dans certaines villes du Midi . . (Luchaire, pp. 365-366, 401, 420-443). 
Philippe le Hardi to Roger Bernard, had stipulated a time of seven years to elapse before the transfer should become effective. ${ }^{46}$ The King of France died less than a month after the agreement of Villanueva was effected. The heir to the throne confirmed the pact. ${ }^{47}$ Roger Bernard, who would not wait his allotted seven years, then moved to gain possession of Pamiers by the consultation and the consent of the people in the manner described. The Abbot resisted his attempt. Roger Bernard, in spite of his pact and agreement, was compelled to wait. In February, I295, ten years after the first agreement and the popular expression of consent, "Parliament ordered that "the hand of the king be lifted from the city and the castle of Pamiers." "48 It seems, then, that the consent of the people of Pamiers was appreciated and heeded by no one except Roger Bernard himself, whose interest would be directly furthered by it. The conditions of the royal patent, approving the transfer of Pamiers without the consent of the free inhabitants, and the opposition of the Abbot to the transfer were both held superior to and more effective than the expressed desires or consent of the people. It should be mentioned, however, that the royal letter of approval of 1285 admonished the Abbot, the Conventus, and the people of the city to prove themselves tractable and favorably and benevolently inclined towards an agreement with Roger Bernard. ${ }^{49}$ While this request tends to show a certain amount of consideration for the people of Pamiers on the part of the king, it does, on the other hand, rob the supposedly free choice in favor of the new master of that vestige of spontaneity which Solière wishes to attribute to it.

In 1420 Amédée VII, the first duke of Savoy, having bought the Comte de Genevois, planned to annex also the city itself. However, the Conseil général of Geneva suc-

${ }^{46}$ Lettres inédites de Philippe le Bel. . . . Avec une introduction par Ad. Baudouin, Paris, I887, pp. xxii, 126.

47 Ibid., pp. xxiii, I29.

49 Ibid., p. xxiii.

49 Ibid., p. I27. 
cessfully opposed his plans. "Ecclesiastics and laymen, merchants, the military, proprietors and commoners, all inhabitants of Geneva, without exception and distinction, took seat, equal before the law, in that sovereign assembly' and with unanimous voice resisted the abdication which was to be imposed on them." "so Here we seem to have the first case on record where the whole population of a city, without exception and without distinction and all equal before the law, assert their own will in matters of allegiance; to all appearances a case of plebiscite answering the strictest tests of the present day champion of popular rights.

Still, the principle underlying the refusal of the people of Geneva to be annexed must be sought less in the insistence on the popular right of self-determination than in the consciousness of an established privilege. "It was a matter of franchises which Geneva had received in the fourteenth century from Fabri, one of its prince-bishops, privileges which were not subject to revocation by Fabri's successors." ${ }_{51}$ Even in this case, then, the question of policy was the stronger motive governing the choice of the means to the end.

In his Etude sur la réunion de Montpellier au domaine royal (I349), ${ }^{52}$ A. Molinier discusses the complicated feudal reiationships of Montpellier. Describing the passing of this barony in the year 1236 as an arricre-fief under the suzerainty of the Bishop of Maguelonne to Jayme I, King of Aragon, Molinier does not refer to a plebiscite or to any other mode of expression by the populace. Nor does it seem that the inhabitants had any voice in the assumption of suzerainty in 1293 by the King of France over the feudal lordship of the bishop.

In the year I34I Don Jayme, King of Majorca, who had come into the arrière-fief rights of Montpellier, solicited the support of the inhabitants of the fief against the King of

50 Solière, p. 15.

51 Ibid.

$52 \mathrm{~A}$. Molinier, Etude sur la réunion de Montpellier au domaine royal (1349) in Revue historique, 1884, vol. xxiv, n). 249-302. 
France whose suzerainty he refused to recognize. As to the result of his solicitations the authorities conflict. One source states that Jayme succeeded in gaining the assistance sought. Another, a contemporary report, claims, according to Molinier, that, "to the contrary, the consuls and notables remained neutral in the quarrel and only affirmed their respect for their two suzerains." "53 We have here a request for support, military or moral, or both, implying of course a practical expression or manifestation of preference for one side-the side seeking it. The possibility of a choice is not implied in the request, though it is manifested in the action of the consuls and notables showing a determination in the negative direction.

The annexation of the Kingdom of Majorca to the Kingdom of Aragon in the year I344 was the result of the war between the two countries. To quote Molinier:

The act uniting Roussillon and Cerdagne to the Kingdom of Aragon was read in the Church of Saint Jean in the presence of the people. The rest of the country seems to have submitted without resistance, and within the following months the officers of Pierre over-ran Conflent, Vallespir and Cerdagne, receiving the homage of the nobles and the oaths of the communities. Later, Don Jayme [King of Majorca] accuses his subjects of treason toward himself; this term was perhaps too strong, but one must recognize that they resigned themselves easily to this change of masters, either fearing the power of Aragon or being weary of a struggle the issue of which was certain in advance. ${ }^{.4}$

We have here a case of resignation without even the pretense of an attempted self-determination in the form of a plebiscite or otherwise.

When the former King of Majorca was finally forced by his indebtedness incurred in consequence of his three wars with $A$ ragon to sell his title to Montpellier to the King of France, the latter legalized the sale by treaty. Molinier mentions that "the sale was then confirmed by the children to the King of Majorca." Whether the inhabitants of Montpellier or the consuls and notables were consulted he does not say. ${ }^{55}$

\footnotetext{
53 Molinier, p. 263.

54 Ibid., pp. 295-296.

55 Ibid., p. 300.
} 
The deductions to be drawn from the case of the feudal relations of Montpellier as presented by Molinier would indicate that at least in the I 4 th century transfers of fendal allegiance from one seigneur to another actually took place without the previous solicitation of the consent of the consuls and notables of the fiefs concerned. They scem to imply further that many more settlements, especially of armed conflicts involving transfer of territories, were made during those medieval feudal struggles without the consent of the smaller vassals and that of the notables of the cities and villages thus transferred.

Solière's affirmation "that in the I th century and at the beginning of the I 5 th century it is a rule, generally enough admitted, that no annexation can be pronounced without the assent of the people or of the notables" seems to be untenable in its given form if we assume, as we should, assent to mean voluntary choice and not inevitable submission. It becomes tenable only if we limit the cases of annexations to transfers by peaceful means excluding those forced by conquest in consequence of the defeat of the former holder. Nor need we hesitate to insist that his identical affirmation for the 12 th and $\mathrm{I} 3$ th centuries are subject to the same qualification.

The proposed cession of Guyenne to England in 1344 involved the complete surrender of French soil to a foreign potentate. Discussing the case, the cardinals meeting in Avignon expressed themselves in effect as follows:

It did not seem possible to them that the Duchy of Aquitania could thus be separated from the crown of France and be assigned to the King of England so that the latter would hold it free, [libcre] because even if the King of France were willing to give his consent, the country [regnum] nevertheless would object nor would it permit that the property of the crown be thus divided, which from antiquity was together [integra]; nor would the people [gentes] nor the community of the said duchy permit that such be done, who did not wish to be subjected to one so much different from themsclves [qui nollent precise subjice (sic) alteri corum tantum]. ${ }^{5 B}$

56 Solière, pp. 15-16. 
This is a case wherein we have to deal not only with the consent or refusal of assent of the people to be transferred but also of the will of the entire nation in the matter of transfer of any of its parts.

With the decline of feudalism at the end of the $13^{\text {th }}$ century the former feudal lordships concentrated around the king as the strong national figure representing the multitude of former feudal lords as the national sovereign. "Gradually even the larger seigneuries fell into the hands of the representatives of the monarchy." ${ }_{57}$ A national consciousness arose out of the Hundred Years War. The kingdom was reestablished on a stable basis. Assemblies of the three social states came into being for the established provinces and for the entire kingdom. The principle that the seigneur could not cede his vassal to another lord without the former's consent was extended to the realm in the sense that the king as sovereign could not cede French territory to a foreign potentate without the consent of the Etats Généraux as the representative body of the realm. The principle of the inviolability of French soil was born $;^{58}$ the same principle by which Thiers tried to prevent the cession of AlsaceLorraine after the Franco-Prussian War.

"In general the chief feudal states have all taken proper measures to assure the perpetuity of their dynasties by proclaiming the indivisibility of their power and of their domain. They have suppressed the custom of partition, and they have let the integral transmission of the seigneurie to the oldest male pass into law." 59 We should not find it difficult to see in this practice the motive for the principle of the inalienability of the realm as applied to the entire kingdom, especially if we consider that the holders of these chief feudal states sat as representatives of their state in the Etats Généraux with which, as has been stated, lay at least nominally the right of consent or refusal in the case of any proposed surrender of French soil to a non-French ruler.

${ }^{57}$ Luchaire, p. 244.

${ }^{58}$ Solière, p. 3 ; see also below, p. - note -

50 Luchaire, p. 239. 
Solière cites and describes in some detail a number of cases where treaties stipulating the cession of French territory to England were submitted to the Etats Généraux for their approval and he calls these cases plebiscites. He says:

We shall now examine the plebiscite by the Etats Généraux. Here... we are in the presence of regularily constituted bodies which are to be consulted by royalty! It seems at the first glance, that these cleclarations of the Etats Généraux should be compared to the ratifications of treaties which under a constitutional régime the sovereign must ask nowadays of the representatives of the nation, rather than to plebiscites. However, it must not be forgotten that the deputies to the Etats Généraux were, in matters of their powers, subject to a régime which is called the mandat impératif. They were obliged to present the complaints and objections with which they were charged by their constituents. . . . The king's letters of convocation specified the affairs for which they were convened and they recommended to the Three Orders that they give to their representatives sufficient powers for the expedition of the affairs specified. Consequently; when the Etats Généraux ratified or rejected this or that treaty, it did so in accordance with the will of the electors; it was a plebiscite in two degrees. ${ }^{60}$

Luchaire's description of the rights and powers of the Etats Généraux does not seem to justify Solic̀re's interpretation. The two privileged orders were convoked by a royal lettre de semonce.

The third estate, convoked by hailiffs and seneschals, comprised under the name bonnes villes and villes insignes, the entire urban population not only of the domain, but of the kingdom. ... In the cities which possessed a municipal organization, the procureurs, charged with the representation of the people in the Etats, were elected either by universal suffrage (even the women having the right to vote on certain points) or by restricted ballot through the same electoral colleges which elected the magistrates. In the localities dependent upon seigneurial or royal power, or being without municipal organs, the deputies were designated by general assembly of the inliabitants, or even by the seigneur in accord with the latter. ${ }^{61}$

Concerning the mandate of the deputies, Luchaire writes that "it must have been conceived in the most general terms, in such a fashion as to give them the most extended powers." Differing most radically with Solière's conception of the function of the Etats Généraux, he further states:

so Solière, p. 18.

61 Luchaire, p. 503. 
The authority of the first General States, in spite of their universality of convocation, was circumscribed within the limits of the solemn assemblies of the period prior to I302. They had neither the right of initiative, nor the right of deliberation and free discussion. Royalty demanded of them simply, as in the past, adhesion, support, ratification of measures already effected or to be taken. The importance of their role under Philippe le Bel and his sons lay singularly in the solemnity and the gravity of the circumstances which had caused its convocation and not in their effective power. And so was the deputation to the Etats during that period considered as an onerous obligation rather than as a political right. ${ }^{62}$

About ten years prior to the appearance of Solière's study De la Guéronnière in his Le droit public et l'Europe moderne $e^{63}$ cites two cases of treaties providing for the cession of French territory, the one being submitted for ratification to the Etats Généraux in 1359; the other in 1527 to the representatives of the Bourgogne, the territory to be ceded. In both cases the decision was adverse to the acceptance of the treaty. De la Guéronnière sees in these two cases the germ of the principle of the plebiscite. Rouard de Card concludes his review of these same cases with the following observations: "Without doubt, these two historical facts present a certain interest from the political point of view, but they can not be considered as the origin of the theory which we are studying. We must not remain on the surface nor must we let ourselves be deceived by appearances. Be it noted first that in these two cases we find no trace of a popular vote. We stand in the presence of regularly constituted assemblies composed of privileged members." 64 He mentions the fact that in the Treaty of I359 not only the representatives of the territories to be ceded to England, but those of the entire kingdom, were called together and that the decision by them does not resemble our modern plebiscite but "the ratification of treaties which the sovereign under a constitutional régime must nowadays ask of the representatives of the nation."

62 Ibid., pp. 503-504.

63 See E. Rouard de Card, Les annexions et les plébiscites dans l'histoire contemporaine, in his Etudes de droit international, Paris, I890, p. 42.

64 Ibid., pp. 44-45.

65 Ibir. 
But even this method of ratification of treaties stipulating cession of French territory to foreigners was destined to fall by the wayside. Besides, the principle of ratification of treaties by the Etats Généraux met in practice with a severe handicap in the power of the king to dissolve by lettre de jussion the recalcitrant Assembly. ${ }^{68}$ Nor did the kings of a later period seem to consider themselves bound to submit treaties to the Assembly. "In 1712 Queen Anne demanded that the prelininarics of the treaty signed the preceding year at Utrecht be ratified by the Etats Généraux. Louis XIV was not willing to concede this. From that time or the formality of registration fell into desuetude. The treaties carrying with them the cession of Canada to England and of Louisiana to Spain were not registered ( 1763 ). These two alienations were effected contrary to the wishes of the inhabitants. New Orleans was 'freed by force' (1769).",

Before we pass on to the revolutionary plebiscites there remains to be considered one more feature of the plebiscites of the time between the feudal and the revolutionary periods. While France developed and applied the principle of inalienability or inviolabilty of French territory, she failed at the same time to concede the right to, and the application of, this doctrine to other nations. This inconsistency found its manifestation in the contemporary wars of conquest waged against the Germanic Empire, culminating in the acquisition by France of many territories situated on the left side of the Rhine, chiefly in the regions known as Alsace-Lorraine.

Solière cites the annexation of Metz, Toul and Verdun (1552) among the cases of cession by plebiscite. However, his version, if analyzed, would exclude the annexation at least of Metz and Toul from this class. The following is Solière's presentation: "When in the year I552 King Henry III [that is, II] annexed the bishoprics of Metz, Toul and

${ }^{66}$ Solière, p. 3.

67 Ibid., pp. 3-4. 
Verdun, Bishop Robert de Lénoncourt said to the inhabitants of Verdun 'that the King of France had come as liberator, that he wished to treat the bourgeois as good Frenchmen, and that, far from using rigorous measures, he appealed to the free vote of the people." "'as Solière concludes with the assertion that "it was by universal suffrage that the new French citizens were untied from the old yoke." ${ }^{9}$ Assuming Solière's statement to be correct, we find that the solicitation of the free expression of consent by the inhabitants of Verdun took place after the king had come to Verdun to stay. The reference to rigorous measures, even if it is a negative one, sounds more like an expression of warning than of sympathy.

Ollivier calls this case of popular expression of consent in Verdun absolutely exceptional. ${ }^{70} \mathrm{He}$ discountenances the theory of intervention practiced in the past by all nations and justified by Languet in his Vindiciae contra tyrannos ${ }^{71}$ if it is disinterested and free from all thought of aggrandizement, but he holds that the right of the people to pronounce itself concerning its own destinies in case of conquest was not conceded. ${ }^{72}$ In connection with the annexation of the three bishoprics, Ollivier quotes Sully, who, "a little later, in the way of advice to the conqueror laid down the norm "not to undertake lightly to join in one body of state those whom an aversion of mind or contrariety of language, laws and customs might render incompatible, in view of the fact that the most happy and secure dominations were those wlose subjects obeyed voluntarily, freely and joyfully." "73 The position taken by Ollivier and the

${ }^{68}$ Solière, p. 26. Solière's phraseology is found in E. Ollivier, L'Empire libéral, 2nd ed., Paris, I895-1915, vol. i, p. 165, with the one difference that Solière's "Henry III" appears correctly as "Henry II." Ollivier gives as his source, Janssen, Frankreich's Rheingeluiste, p. 28 , which could not be secured for the present study. ${ }^{69}$ Solière, p. 26. The identical statement is found in Ollivier, vol. i, p. I65.

70 Ollivier, vol. i, pp. 164-165.

71 Cited by Ollivier, vol. i, p. 165 .

72 Ibid.

73 Ibid. 
warning expressed by Sully can give little substance to the claim of those who wish to present the case of Metz, Toul, and Verdu11, or at least of Verdun, as instances of cession by consent. In fact it is quite possible to adduce reputable evidence to the effect that, whatever consent was given was nothing short of an acceptance of the inevitable. Le Bas, for instance, describes the capture of Metz as a ruse. The people of Metz were told by their bishop, Cardinal Lénoncourt, that the King of France was marching into Germany to establish freedom and that he desired nothing but quarters in Metz; and so Le Bas writes, "the city having thus fallen into the power of the King of France, the bourgeois were forced to render to him the oath of fidelity." ${ }^{\prime 74} \mathrm{He}$ then relates how the French army passed through Luneville and Sarrebourg (Saarburg), entering Alsace through Saverne (Zabern). The King's connćtable "presented himself en effet before Strasbourg, accompanied by two hundred of his bravest soldiers who passed as ambassadors curious to see the city. But the inhabitants having learned in advance of the coup planned against them . . . received them by an artillery volley which killed ten or a dozen and forced the others to flee. . . ." As related by Le Bas, "the cities of Toul and Verdun were taken by ruse like Metz, and these three cities have remained since then with France."75 For "Henry II had at first announced that he was guarding them for the Empire, but after he had mastered them he declared haughtily that he wished to unite them to his monarchy and he recalled that the entire left side of the Rhine had formed part of the Kingdom of France under the Merovingians and Carlovingians." 78 The emperor's attempt to reconquer the lost cities miscarried through the failure of his siege of Metz, on January I, I $583 .{ }^{77}$ The Treaty of Muenster of

i4 P. Le Bas, France, Annoles historiques, Paris, 1840-1843, vol. i, pp. $316-320$.

75 The same version of the conquest of these cities is found in E. Lavisse, Histoire de France, Paris, 1900-19II, vol. v, part 2, pp. I 49-150.

76 See note 74 .

77 Ibid. 
I648 confirmed not only the acquisition by France of these three bishoprics, but of all its conquest on the left bank of the Rhine comprising practically all of Lorraine and Alsace formerly belonging to the Germanic Empire. Having once come under French sovereignty, these countries were of course now subject to the doctrine of the inviolability of French soil and could never be ceded without the consent of the entire nation. ${ }^{78}$

We thus find practiced in France in the sixteenth century a policy of opportunism which recognized, or even insisted upon, the principle of popular self-determination in the transfer of cities and territories if such self-assertion was favorable or could be forced into an expression favorable to France, but which refused to acknowledge any voice or opinion to those it wanted to conquer against their will, or to any section of the kingdom which for some reason or other might wish to sever its former voluntary or forced connection with France. One cannot ascribe to this period and the cases discussed the practice and character of popular consent in the establishment of sovereignty.

is It was on the principle of the inviolability of French soil that at the end of the Franco-Prussian war, Thiers solicited neutral Europe's aid against the cession of Alsace-Lorraine to the new German Empire. See below, pp. I74-175. 


\section{CHAPTER III}

\section{The Plebiscite in the Frencil Revolution}

The French Revolution, itself the product of a growing resentment by the tiers éfat against the oppression to which they had bcen subjected by and in favor of the two other estates, proclaimed and defined liberty as the power to "do all that does not interfere with the doings of one's neighbor." 1 According to article 4 of the Declaration of the rights of man and citizen, proclaimed by the Constitutional Assembly in August, I789, "the exercise of the natural rights of everyone [chaque homme] has no limitations save those which assure to the other members of society the enjoyment of those same rights. These limitations cannot be determined except by law." Less than a year later the same Assembly passed a decree which stipulated that "the French nation renounces the undertaking of any war for the purpose of conquest, and that it will never employ its forces against the liberty of any people."

To place the plebiscites, or rather the annexations by plebiscites, of revolutionary France in their proper perspective and to give them their due historical appraisal we must consider them in the light of these expressions and pledges.

First in line is the acquisition of Avignon and Venaissin

1 Article 4 of the Déclaration des droits de l'homme et du citoyen, adopted Aug. 21, 1789. (Arch. parl., ser. I, vol. viii, p. 464.) Revised edition of the Declaration of June 23, 1793, Article 6: "La liberté est le pouvoir qui appartient à l'homme de faire tout ce qui ne nuit pas aux droits d'autrui: elle a pour principe la nature; pour règle la justice; pour sauvegarde la loi: sa limite morale est dans cette maxime: Ne fais pas à un autre ce que tu ne veux pas qu'il te soit fait" (Arch. parl., ser. I., vol. 1xvii, pp. 106-107).

2 See note 1 .

3 Decree of May 22, 1790: “. . l'Assemblée nationale déclarant, à cet effet, que la nation française renonce à entreprendre aucune guerre dans la vue de faire des conquêtes, et qu'elle n'emploiera jamais ses forces contre la liberté d'aucun peuple" (Arch. parl., ser. I., vol. $\mathrm{xv}, \mathrm{p} .662$ ). 
in I79I. These two provinces, situated in the Provence, formed part of the Papal States, but by ties of nature belonged to France. The subject of their incorporation in the French State was first brought before the National Assembly on November 12, 1789, by the Jacobin Bouche of the Provence. ${ }^{4}$ In June, I790, a petition and a deputation were sent from Avignon to Paris requesting union with France. Introducing the petition in the French National Assembly on June I7, M. Camus stated that "the anniversary of the Constitution should be celebrated in the National Assembly by a great event. Penetrated by admiration and respect for the decrees of the National Assembly the Avignonais have unanimously decided to unite with France.

. The petition for reunion was sent by special courier to MM. Camus and Bouché, deputies to the French Assembly, and was signed, "Raphel, Couls, Peytier, Blanc, Richard, officiers municipaux." The letter read in part as follows:

Gentlemen, you have been informed at the time by M. Raphel, one of us, of the events which have succeeded each other rapidly in our city: he has communicated to us your responses and the obliging offers of service which have been made to him for the city of Avignon. Gentlemen, the moment to accept these offers has arrived. Thursday, the Ioth of this month, our city has been the scene of the greatest disorder. The aristocrats, mustering all their forces, fired from all parts. Masters of the City Hall and of seven pieces of cannon, they cried: Vive l'aristocratie! More than thirty persons, honorable citizens, good patriots, have been the victims of their zeal and patriotism; the people marched against the aristocrats with intrepidation and the cruel assassins, dispersed, have sought salvation in flight. Four of these wretches [scélérats] have been arrested and sacrificed by a people, justly indignant, and horribly massacred [assassiné]. . . The municipality has vainly made all efforts to prevent this. Twenty-two, also arrested, would certainly have been sacrificed except for the help of the national guards of Orange, Courtheson, Jonquières, Bagnols, le Pont-Saint-Esprit, ChâteauRenard and other places. Their generous efforts and the confidence of the people of Avignon in their allies, the French, have stayed their vengeance. ... Quiet has almost been re-established; but, in order to insure it entirely, the national guards of France have kindly consented to lend us for a few days part of their detachment. Day before yesterday at eleven, the districts assembled in order to consider their position. The union [with France] has been decided upon unanimously. ...5

4 Arch. parl., ser. I, vol. x, p. 4. Motion for incorporation, with historical and political justification is found, ibid., pp. 208-2I5.

5 Ibid., vol. xvi, pp. $256,369,45$ I. 
On June 26 a deputation from Avignon was admitted to the French Ascembly where one of its members delivered in person a request for annexation to France. His address was greeted with applatse and was farorably commented upon by the President of the Assembly, but no debate enstred. ${ }^{3}$ M. Tronchet's interrupted speech of August 24 brought no decision. ${ }^{7}$ On the 16 th and 18 th of November Pétion de Villenetuve, stupported by Robespierre and others, spoke in favor of the demand made by the revolutionists of Avignon; still the opposition prevented any definite action. $^{s}$ On the zoth the case was once more deferred but a motion was passed advising the king to send troops to Avignon, where violent fighting with Carpentras, the capital city of Venaissin, had broken out. ${ }^{2}$ In the following year, I791, the petition for incorporation with France was again argued and especially advocated before the Assembly by $M$. de Menon on April $30^{10}$ and by Pétion and others on May 5.11 M. de Menou laid special stress on the "legality" of the plebiscite and on the result of the voting which had taken place in Avignon and Venaissin. In the latter, of 98 communities, 59 had declared for union with France. After spirited debates, the Assembly, on May 24, defeated the motion for incorporation, 374 voting for, 394 against, annexation. ${ }^{12}$ The motive for this negative decision is found in a speech by M. Clermont-Tonnerre of May 24, of which a few sentences suffice to illustrate the point in question. He said in part:

The vote of June has been abandoned. It was in point of fact too near the menace which had produced it. But there have been laid

6 Ibid., vol. xvi, pp. $476-477$.

7 Ibid., vol. xviii, pp. 248-249.

8 Ibid., vol. xx, pp. 474. 521, 523-534.

9 Ibid., vol. $\mathrm{xx}, \mathrm{pp} .559-580$. The decree recommends " the sending of troops to Avignon, in order to protect there... French establishments, and in order to maintain there, in concert with the municipal officers. peace and public tranquility."

10 Ibid., vol. $\times x v$, pp. $452-472$.

11 Ibid., vol. $x \times v$, pp. $585-586,593-594$.

12 Ibid., vol. xxvi, pp. 362,382 . Freudenthal, Die Volksabstimmung bei Gebietsabtretungen und Eroberungen, Erlangen, I89I, p. 2. For details of the voting see $\mathrm{S}$. Wambaugh, A Monograph on Plebiscites, New York, 1920, pp. 36-40. 
before you later votes. These are the successive votes cast within the space of a very few months, cast before the French national guards; cast almost always by the dominant factions, arms in hand; cast in the absence of a multitude of the inhabitants driven out by the violence of the dominant party. . . . It is in the absence of this considerable part of the people that they have cast this vote [émis ce voeu]. This absence has not been voluntary; it is the consequence of an act of rigour, an act of injustice; it is the consequence of continued persecution. ...

Having scrutinized the motives of the pro-annexationists he referred to the fact that the advocates of annexation had adduced in support of their policy the expression from other French cities in favor of the reunion of Avignon with France and he claims that "this is rather a weapon in the system of those opposed to reunion." For, so he continued, "it is the desire of the French to unite with themselves the people of Avignon; it is this French influence, which we cannot mistake, this influence which has existed since the beginning of the revolution, which will render suspicious to the veritable friends of truth, all that has been laid before you as the free will [or vote] of the people of Avignon. . .."13

Furthermore, de Menou himself, the most ardent chan1pion of the annexationists' cause, referring to the first vote of June, I790, admitted that "one could object . . . that it was taken in the midst of tumult, disorder and the massacre of several citizens." ${ }_{14}$ The series of later petitions and attested votes referring to the voters speaks of "un voeu formé par les citoyens actifs d'Avignon, pour se réunir à la France." One of these petitions attests the rendering of the oath on the French Constitution by "toutes les gardes nationales d'Avignon." ${ }_{15}$ A letter addressed to the King of France, asking him for speedy annexation and begging him not to permit "that a good people perish because it wishes to become once more French" is signed: "Sire, de

${ }^{13}$ Arch. parl., ser. I, vol. xxvi, p. 365. See also his speech of Nov. 20, I790, ibid., vol. xx, pp. 559-563.

14 Ibid., vol. xxvi, pp. $362-364$. In this connection see also the petition for annexation of June, I790, for which see note 5 .

${ }_{15}$ Ibid., vol. xxvi, pp. $362-364$. For a definition of the term citoyens actifs see above, p. 25 , note 48 ; also Wambaugh, p. 37. 
Votre Majesté, les fidèles sujets, les maire [sic!] et officiers municipanx de la ville d'Avignon, Richard, maire, Coulet, officior municipal, L. Sauvan, l'aîné, officior municipal, Miel, officicr municipal, J. Gérard, officier municipal, Namug, notable commissaire, Descatte, notable commissaire. Avignon, I6 mai 179I." 16

The discussion was reopened the following day. The attempt to reverse the negative decision failed, but a resolution was passed to send a commission of three mediators to use all possible means to prevent the forces fighting in the Comtat de Venaissin to enter French territory; to recall all French soldiers from the forces of both parties to the civil war; to punish recruiting in France for either party; to settle the dispute between Avignon and the Comtadin and to induce them to "cease all hostilities as a necessary provisory to any ulterior step in relation to the rights of France over those lands." 17

Finally, on September I4, I79I, the Assembly passed a favorable vote on the question of annexation in the form of the following decree:

The National Assembly having heard the report of its diplomatic commission and the report of the Commission from Avignon. ...

Considering that the majority of the communes and citizens have expressed freely and solemnly their wish [vocu] for union of Avignon and of the Comtat of Venaissin with the French Empire:

Considering that, by its decree of May 25 last, the rights of France to Avignon and the Comtat Venaissin have been formally reserved:

The National Assembly declares that in virtue of the rights of France to the united states of Avignon and the Comtat of Venaissin and that in conformity with the freely and solemnly expressed wish of the majority of the communes and citizens of these two countries to be incorporated with France, the said two united states of Avignon and the Comtat Venaissin are, from this moment, an integral part of the French Empire. . . ${ }^{18}$

${ }_{16}$ Arch. parl., ser. I, vol. xxvi, pp. 362-364.

17 Ibid., p. 46I : “... d'envoyer des médiateurs qui interposent les bons offices de la France entre les Avignonais et les Comtadins et fassent tous leurs efforts pour les amener à la cessation de tonte hostilité, comme un provisoire nécessaire avant de prendre aucun parti ultérieur relativement aux droits de la France sur ces pays."

${ }_{18}$ Ibid., vol. xxx, pp. 63I-632. G. F. von Martens, Recueil des principaux traités d'alliance, de paix, de trêve... Gottingue, I79II80r, vol. vi, pp. 400-40r. 
In consequence of this decree Pope Pius VI, through Cardinal Rezzonico, sent a protest to the Catholic Powers of Europe, opposing the incorporation as " a manifest violation of the law of nations," condemning the revolutionary character of the theories involved in such plebiscites and expressing criticism of the result of the votes. This protest ran in part as follows:

As far as the supposedly free wish of the rebels is concerned it is clear that it could absolutely not be accorded without disturbing general peace [repos]. Will it then be permitted henceforth to everybody to choose a new master in accordance with one's pleasure? [d'après le gré de son caprice?]. For such would be the consequence of the principle adopted by the National Assembly. ... .

What the Assembly calls the free and solemn vote of the city of Avignon, which before the revolt had 30,000 inhabitants, is nothing but the signature of about 1000 citizens, extorted under the menace of death, for that only is the actual number of those who, together with a horde of brigands which established itself in the city after the emigration of the nobility and the majority of the respectable people, form all the commune. The rest was forced to leave the country through fear of the satellites in the pay of the National Assembly.... The inhabitants of the Comtat [Venaissin] were forced the same way into this supposedly free vote, by the most fearful pillages.... This free and solemn vote, on which the decree of Sept. I4 is based, is the result of all these cruelties. .. .

Was it not necessary that also the astonishing number of emigrants from Avignon and from the other communes of the Comtat [Venaissin] . . . cast their vote if it was a free and general consensus of the entire province that was desired? Why then were they not consulted?. . .19

19 Freudenthal, pp. 3-4; Martens, vol. vi, pp. 402-4Io; Arch. parl., ser. I, vol. $\mathrm{xxx}, \mathrm{pp}$. 64I-644. Another papal protest, addressed to all the European powers, is found in the same volume, pp. 439-400. Condorcet, defending France's annexation of these Papal territories, stated in the National Legislative Assembly on April 20, 1792, that "what the Pope possessed in this land was the emolument [salaire] of the government functions," that "the people, in depriving him of these functions, have made use of a power which a long servitude had suspended, but which it had not been able to destroy," and that "the indemnity proposed by France was not even required in justice" (Arch. parl., ser. I, vol. xlii, p. 2I2). On the same occasion Condorcet refers to the indemnities offered by France to certain German princes for the relinquishment to revolutionary France of their feudal rights in the territories of Alsace, over which France had gained sovereignty in the Treaty of Münster, in 1648. This relinquishment was enforced in consequence of one of the first acts of the French revolution decreeing, on Aug. 6, 1789, the abolition of feudalism: “L'Assemblée nationale détruit entièrement le régime féodal; elle decrète que, dans les droits et devoirs, tant féodaux que censuels, ceux qui tiemnent à la main morte réelle ou personnelle, 
The note, so concludes Freudenthal, was laid ad acta; "it could not change a fait accompli."

The papal protest laid great weight on the manner of application of the plebiscitc. For this it found sufficient cause in the fact that deputy de Menou on May 5, I 791 , had pressed the case on the strength of the "legality" of the plebiscite and in the further fact that the decree of annexation takes specific cognizance of the freely expressed will or vote of the majority of the communities for annexation. The same papal note asserted that in the past the inhabitants of Avignon and the Comtat had more than once appealed to their former sovereigns, the Popes Gregory XI, Nicholas V, Calixte III, and Paul III, to be permitted to remain under the rule and law of the Apostolic See, and that "at the first news of the designs of the National Assembly on the provinces in November, 1789 , the city of Avignon ... renewed unanimously on December Io, of this year, and all the inhabitants of the Contat on November 25 , the solemn declaration of their desire to remain true and obedient to the reigning Popes." 20

One must not lose sight of the circumstance that the repeated adverse decisions of the petition of the people of Avignon by the French Assembly and the latter's insistence on sending a committee of mediators, as well as the conspicuous stress laid upon the action of the mediating body in the final decree of annexation, clearly point to the principle of intervention rather than that of popular self-deter-

et à la servitude personelle, et ceux qui les représentent, sont abolis sans indemnité. Tous les autres sont déclarés rachetables, et le prix et le mode du rachet seront fixés par l'Assemblée nationale ..." (Ibid., vol. viii, p. 356). See also Solière, pp. 32-37.

${ }^{20}$ On Nov. 20, I790, the Abbé Maury introduced in the Nationai Assembly the texts of a resolution of the States of the province of the Comtat and of a letter from the City of Avignon to the Pope. The resolution states that, upon the news of the motion for union of Avignon with France made in the French Assembly by a member from the Provence, the States of the province of the Comtat have gathered to vote by ballot on the question of loyalty to their present sovereign, the Pope. Each person present having cast his vote, it was found to be unanimously in favor of dispatching to the Pope a letter asserting their unfaltering allegiance (Arch. parl., ser. I, vol. $\mathrm{xx}$, p. 573). 
mination on the part of the annexed as the basis of incorporation in the French Republic. ${ }^{21}$

After the case of Avignon and Venaissain had set the example, the growing spirit of the Revolution, with its fascinating theory of liberty and sovereignty of the people, induced the discontented population of a number of neighboring territories to assert their independence from former claimants of their allegiance and to vote for incorporation in the French Republic. This movement found special impetus and support in a French decree of November I9, I792, in which republican France promised aid and succor to all the peoples who desired to regain their liberty. ${ }^{22}$

Typical of the manner in which these secessionists proceeded is a declaration of deputies of the bishopric of Basel, " united in the Constituent Assembly in the Château Porentruy, on November 27, I792, the first year of the Republic of Rauracie."

${ }^{21}$ See also note 85 . In his justification of the French declaration of war on the King of Bohemia and Hungary, read in the National Legislative Assembly on the 2oth of April, I792, Condorcet declared it to be the principle of the French revolution that "every nation alone has the power to make its own laws, and the inalienable riglit to change them, that the will to deprive any foreign people by force of this right is equivalent to the admission that one does not respect this right even in the country of which one is citizen or clief, that it is equivalent to betraying one's fatherland, to becoming an enemy of the human race" (Arch. parl., ser. I, vol. xlii, p. 21I). Nevertheless, when the French Assembly, on Nov. I9, voted fraternal help to all peoples desirous of regaining their liberty, the English Cabinet saw in this decree a covert attempt at interference in the affairs of the neighbors of France, especially as far as Belgium and Holland were concerned; and shortly after the inauguration of the French Republic (Aug. Io, I792) England interrupted all diplomatic relations with France and soon began to prepare for armed conflict. In his address of Dec. I0, I792, delivered to the Assembly on the subject of France's relations with Britain, Le Brun, the French Minister of Foreign Affairs, gives as one of the reasons for the British attitude the decree of Nov. 19, 1792 (Ibid., vol. 1v, pp. I64-I65).

22 "La Convention nationale déclare, au nom de la nation française, qu'elle accordera fraternité et secours à tous les peuples qui voudront recouvrer leur liberté, et charge le pouvoir exécutif de donner aux généraux les ordres nécessaires pour porter secours à ces peuples, et defendre les citoyens qui auraient été vexés, ou qui pourraient l'être pour la cause de la liberté" (Arch. parl., ser. I, vol. liii, p. 474). 
We, the deputies and representatives of the free states of the former bishopric of Basel, fief of the German Empire, united in the National Assembly, under the protection of the French Republic. ...

Considering that the Constitution and the laws of the Germanic Empire are not the result of the general will of the peoples who compose the empire, but of the princes . . . who by usurpation have appropriated various authorities over the peoples forming said nation, contrary to the incontestable... right of sovereignty which radicalement resicles in the people. ...

Considering that the government of the bishops of Basel, who by an abuse absolutely contrary to the maxims of the Gospel, combined temporal power with their spiritual office in accepting the lands and seigneuries of their bishoprics with the exercise of sovereignty over the inhabitants in fief from the Emperor and the cmpire, was an arbitrary and despotic régime... .

Considering further that the public treaties and even the decrees of the highest courts of the empire, notably the imperial judgment of Vienna of 1736 , regulating the fundamental constitution of the land, that the whole body of reciprocal rights and duties between princes and people, far from having been respected by the princes, have always been violated when they stood in favor of the people and that the people's reclamations have always been rejected with scorn and contempt.

Considering that the griefs of the people and the objects of its grievances have multiplied in proportion to the barbaric and tyrannical treatment which the bishop princes accorded the inhabitants of the bishoprics, especially in the case of hunting, the administration of communal forests, the repair and maintenance of public roads, the traffic in salt. etc. . .

Having considered all this we . . declare, in the face of Heaven and Earth, that all the ties which attach us to the Emperor and the German Empire, as well as to the bishops of Basel and to their Chapter, are broken, we swear never to renew them. . . .23

The Assembly of the Republic of Rauracie-this was the name assumed by the former bishopric of Basel-formulated and passed this resolution while under occupation by French troops. ${ }^{24}$ After the adoption of the resolution the Assembly sent a deputation to citizen François Demars, commandant of the French military in the Republic of Rauracie, to acquaint him with the constitution of the new republic and to request of him the execution of the decree of Nov. 19, I792; that is, to ask of him the fraternal aid promised by revolutionary France. ${ }^{25}$

The French Provisional Executive Conncil took cognizance of the revolution of the Republic of Rauracie and of

${ }^{29}$ For complete text see Martens, vol. vi, pp. $426-430$.

24 Ibid., p. 430.

25 Ibid. 
the fact that the new free republic had requested the French military command to support the new state of affairs in accordance with the decree of Nov. I9, I792. In consequence of these considerations it ordered the French troops, stationed near the Rauracian frontier, to hold themselves in readiness to "assure to the Republic of Rauracie the effica." cious and fraternal protection of the French Republic." At the same time it advised its Minister of Foreign Affairs to give to the commissary, previously appointed by the Executive Council, and stationed near the frontier, all instruction necessary to guard over the execution of the decree. . .." By vote of the Assembly of March 8, I793, the Republic of Rauracie decided in favor of union with France. By decree of March 23 of the same year, the French Republic annexed the Republic of Rauracie under the name of Départment du Mont-Terrible. ${ }^{26}$

The presence of French troops in the new republic may of course be explained by the desire of republican France to render, and of the revolting faction in Basel to obtain, assistance against an expected military suppression of the separatist movement by the Germanic Empire, from whose suzerainty the bishopric was seceding. An additional reason, and perhaps the more convincing one, is found in the fact that the government of the new Republic of Rauracie found it necessary to seek the aid of the French military in the enforcement of the new constitution. It is this latter reason, pointing to the internal dissension and disaffection, which finds its substantiation in a letter from the French commissaries to Basel reporting, under date of March I, I793, to the French Convention on the conditions in the bishopric. Among other things they wrote:

On our arrival here, we have found the country divided into two parties, very much incensed against each other. We render justice to whom it belongs; we continue to gather information, but we cannot yet announce anything lest we risk to detach from us the party which we would declare culpable. That is why we shall defer until after the casting of the vote by the inhabitants of the country ... what we have discovered up to the present concerning the facts

${ }^{26}$ Ibid., pp. 430-431. 
imputed to Rengguer, Demars and Gobel. We can tell you... that it is not patriotism which has guided the leaders of each of these parties in anything that has been done here. Rengguer and his adherents wanted a republic for themselves and have cmployed the most vexatious measures to suceed; the other party makes use of the faults of the pretended revolutionists in order to denounce and to render odious a revolution which it attempts to identify with its originators. Today these two parties, on account of their mutual hatred, throw themselves into our arms in order to destroy each other; they are right, for mion with France will cause the disappearance of the hopes of the aristocracy ... as well as the attempts to form a patriciate by a family coalition. It will be true to say that the party chiefs will have given themselves to the French, not because they loved us, but because they detest us less than their own adversarics. It is a case of the application of the proverb: Inter duos litigantes, etc. This little notice must convince you that we cannot make public our information about Rengguer, Demars, and Gobel until the strife of the two parties shall have ceased by reunion. ....27

We nay accept Solière's statement that the desire of the people of Savoy for union with France was based on the identity of language, custons, and ideas, and that their antipathy was not to the King of Piedmont personally but rather to the absolutism of the Sardinian governors and military commandants. ${ }^{28}$

While the French Revolution found its echo in the discontented minds of the Savoyans, friction developed between the French Republic and the Court of Turin on account of the latter's favorable attitude to the French princes and emigrés. ${ }^{29}$ In a letter to the Convention nationale, the French Minister of War, on September 24, I792, announced the invasion of Savoy in accordance with his orders. The invasion was carried out, so he stated, by General Montesquieu, " un homme qui avait profondément médité pendant trois mois tous les moyens d'entrer utilement en Savoie." On September 28 Nontesquieu's own report was read under repeated applause and ordered printed. ${ }^{31}$ In this report he advised the Convention, that "today the tree of liberty shall be planted with great ceremony in the principal place of the city." And he added, "it seems to me that the

27 Arch. parl., ser. I, vol. 1x, pp. 235-236.

${ }^{28}$ Solière, p. 44.

29 Ibid.

30 Arch. parl., ser. I, vol. lii, p. I 16.

31 Sept. 29, 1792 (Arch. parl., ser. I, vol. 1ii, pp. 188-189). 
people are disposed to a revolution similar to ours. I have already heard them speak of a proposal to France of an S4th department, or at least, of a republic under French protection.... It is desirable to know the wish of the Government, for I believe that I shall be in a position to influence the course which may be taken. . ..."32 The same day discussion concerning the fate of the liberated Savoyans began in the Convention nationale. ${ }^{33}$ A motion to invite them to assemble under French protection and to decide on their own destiny was referred to the Committee. ${ }^{34}$ In a proposed address to the people of Savoy, Cloots informed them that the Convention would send them four of its members to guide their first steps and invited them to unite with France. The project was tabled. ${ }^{35}$

In a proclamation of September 21, Montesquieu himself had advised the people of Savoy of his intention of military action against the King of Sardinia. He gave assurance that the French army would enter their country not to devastate their fields but that "a free people comes to offer sentiments of union and amity." "Separate yourselves from your tyrants" was his advice. Finally on October 6 the Commissaries assigned to the Army of the Alps issued a proclamation from which the following quotations require attention:

Brethren and fricnds: Rise from your lethargy; you owe to the French only esteem and recognition; you have nothing to fear from the Piedmontese; and while our armies guard your liberty, busy yourselves to make it secure. ...

Proud of the success of our arms, we could give you orders, but the French Republic has effaced from its annals the words king, master and subjects, ... we only give you advice.

Primary assemblies are the only kind in which the people can exercise their sovereignty.

Hence, we exhort the free people of Savoy to gather to-day, peaceably, without weapons, under the guidance of the French arms, in each commune, in order to nominate a deputy charged to express in a general assembly their wish for a new government. ${ }^{37}$

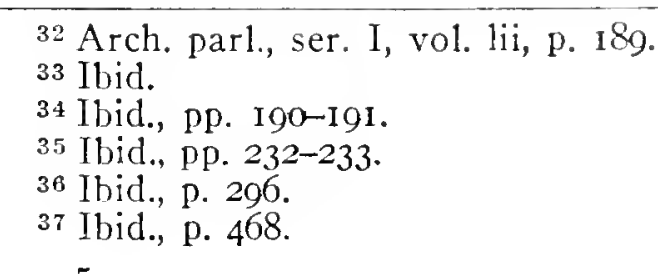


Thus, on October 14, 1792, the citizens of all the communes except three still occupied by the Piedmontese, ${ }^{33}$ gathered in the churches and elected by miversal suffrage the deputies who were to decide the future of their land. A large number of the communes left the form of government to the discretion of their representatives. Of the total of $655 .{ }^{39}$ not less than 6 Io instructed them to vote for mion with France. ${ }^{40}$.

The deputies assembled on October 24 and expressed "the general wish [voeu] of the free and independent nation of the Allobroges to be united to France as an integral part." +1 A Savoyan deputation transmitted a demand for annexation to the French National Convention on November I . ${ }^{42}$ Another deputation, charged by the Savoyan National Assembly with the transmission of their request for incorporation, appeared before the Convention nationale on November 2I. ${ }^{43}$ After a prolonged debate ${ }^{44}$ the French Republic annexed Savoy as the 8fth department on November $27,1792 .{ }^{45}$

In a communication dated October 28, I792, the Corps administratif of the united city and former county of Nice informed the French National Convention of the unanimous wish [vocu] of their fellow-citizens to be united with France. Here, too, occupation by French troops had preceded the fornulation of the request, as is shown by a communication of October 2 I which states that "since the arrival of the French ... the flag of liberty adorns all public places." 46 A letter of the Provisional Judges of the

$3 s$ Ibid., pp. 506-507.

39 Ibid., p. 506. The total obtained by addition of the numbers given for the various provinces as found in the extract of proceedings of the second meeting of the representatives is 685 (Arch. parl., ser. I, vol. liii, pp. 506-507).

$40 \mathrm{M}$. Grégoire gives this number as 580 (Arch. parl., ser. I, vol. liii, p. 611).

41 Solière, pp. 44-49; Arch. parl., ser. I, vol. liii, pp. 506-507. .

42 Arch. parl., ser. I, vol. liii, p. 357.

43 Ibid. pp. 506-507.

44 Ibid., pp. 507-510; 610-617.

45 Ibid., p. 6i7.

46 Ibid., pp. 25, I 46. 
Tribunal of Nice of October 8 speaks of their courageous labors to make the French laws liked (à faire aimer) by applying them with the severest impartiality. ${ }^{47}$ The French Convention of November 4 refused to entertain the request, repeated by a deputation, until presented in the form of a popular free vote. ${ }^{48}$ Ten days later the substance of a letter presented by a deputation from Nice, was presented in the French Convention to the effect that the country (Nice) was being treated as a conquered and rebellious land. The soldiers of the French army had committed great disorders and had given themselves over to obnoxious excesses. "To-day," so they wrote, "the inhabitants, instead of going to meet the French, as they had planned, take refuge in the mountains. ..." The Convention took immediate steps to remedy the conditions complained of. ${ }^{49}$

Nevertheless, in a Primary Convention, called for the purpose of electing magistrates and of discussing the mode of the impending expression of the national vote in the matter of its future political status, dissension broke out. A letter from the commissaries of the Armée du Var speaks of it as sedition which had to be quelled by French troops. The letter charges Piedmontese agitators with the attempt to disunite the people of Nice in order to dissolve the Primary Convention and to bring about disorder and bloodshed to be laid at the door of the French army. ${ }^{50}$

The popular free vote for annexation to France having finally been secured, the National Convention decreed the union on January $3 \mathrm{I}$, I $793 .{ }^{51}$

The enthusiasm of the first months of the French Revolution had found an echo also in the Belgian Netherlands and resulted in the revolution of 1789 and 1790 against

\footnotetext{
4 i Ibid., p. 609.

48 Ibid., p. I 47.

49 Ibid., vol. liii, p. 405 ; vol. 1v, pp. 156-157. See also Saliceti's report which largely discounts these disorders (ibid., vol. liii, p. 567), and the report of the Commissaries of the National Convention to the Armée du Midi (ibid., vol. liii, pp. 633-634).

50 Arch. parl., ser. I, vol. lv, p. 157.

51 Martens, vol. vi, pp. 4I6-4I9.
} 
Emperor Joseph II. Relations between Belgium and the Emperor had already been strained; the French revolution fammed the flame. "Brussels applauded the fall of the bastille and in the l'ark, in the churches, in the streets one found placards bearing the words: "Here as in Paris." ", 52 Open warfare between Belgian volunteers and Austrian troops began in the summer of 1789 . "The Etats of each province assumed for themselves sovereign power, and their mandatories, convened at Brussels in the Etats Généraux to the number of fifty-four, signed on January I I, I 790 , the act of union of the United Belgian States." ${ }^{53}$

Thus Belgium had constituted itself an independent republic. However, civil strife broke out between the moderate revolutionaries under Vander Noot and the extremists under Vonck. The latter appealed for support to the nation; Vander Noot had, without practical results, appealed to the stranger-England, Prussia and Holland. ${ }^{54}$ While Vander Noot was Minister of the new republic, Vonck refused the presidency of the Conscil des finances and of the Cour des comptes. ${ }^{55}$ The Vander Nootists, or statists, controlling the Etats Généraux, branded Vonck as "inventor of odious novelties" and "the Abbé de Feller exclaimed that he would rather recall the Austrians than live under the rule of the cohue nationale française." ${ }^{56}$ Vonck and his adherents fled Brussels and gathered their forces at Namur. The Etats Généraux engaged the Prussian Schoenfeld, recommended by Holland and Prussia, and the Englishman Koehler ${ }^{5 \pi}$ to command their troops. While thus civil war was being waged in Belgium, Emperor Joseph II died. He was succeeded by his brother, Leopold II, who offered complete amnesty to the Belgians with as-

52 A. Chuquet, Jemappes et la conquête de la Belgique (Les guerres de la révolution, iv), Paris, no date, p. 17.

53 Ibid., p. 26.

54 Ibid., pp. I8, 25.

55 Ibid., p. 27.

56 Ibid., p. 28.

57 Ibid, pp. 30-3I, 37. Colonel Bath was in command of the Légion britannique, consisting of some Englishmen and Belgians. 
surance of all privileges formerly held by them under Maria Theresa. His offer and request of submission were refused, as was the suggestion of mediation by the Triple Alliance. The invasion which followed terminated in the subjection of the Belgian Republic to its pre-revolutionary status and the Treaty of peace of December 2, I790, concluded at the Hague. ${ }^{58}$

Revolutionary France, not yet a republic, had watched matters in Belgium with keenest interest. "There is," said Lafayette, "not a Frenchman who does not yield to the Belgian people his applause and good wishes." ${ }^{59} \mathrm{He}$ had, in the beginning of 1790 , sent two of his intimates to Belgium to incite the Vonckists against the ruling conservatist revolutionists. The Austrian successes aroused the French to the fear that the Austrians, once more masters of the Netherlands, could and would from there easily move to intervene in France in favor of the endangered Louis XVI. War between Austria and France prepared the way for French intervention in Belgium. Belgian refugees in France were working for revenge, thus giving the French further incentive and justification for intervention. In April, I792, the French Legislative Assembly ordered the attack upon the Austrians in Belgium. The Minister of War favored a Belgian insurrection and expected such to take place with the appearance of the French. Since the Austrian Government had asked the Etats de Brabant to vote the subsidies required for its war, the French considered it their duty "to invade Belgium without delay, to snatch from the Austrians the gold of the people of Brabant, to give to France 'the resources of a great value which it lacked [manquait]." "'60 The battle of Jemappes or Mons of November 6, I792, decided the fate of the contestants in favor of the French. Within a month all Belgium was in their hands. At the occasion of his entry into Mons, Dumouriez, who had charge of the French cam-

58 Ibid., pp. 35-44.

59 Ibid., p. 46.

60 Ibid., p. 55. 
paing, assured the people that "we come, as brothers and friends, to help you close your doors to your old oppressors and defend the liberty which we have conquered for you." ${ }^{\prime}$ "In the evening . . the people of Mons smashed the imperial crown into pieces and cried: "Vive la République française! Vive le brave Dumouriez! Vivent les sanveurs des Belges!'” Similar declarations by other French officials were mumerons. ${ }^{62}$ The Conscil exécutif in its meeting of November I, I792, had solemnly declared that Belgium need not fear for its independence. ${ }^{63}$ Robespierre announced that the French would leave the Belgian people the liberty of choosing for themselves the constitution they wished to have. The president of the Club of Valenciennes said to Dumouriez: "Make the Belgians free and teach the universe that France finds its glory in the contempt of vain conquests." 64

Nevertheless the French sent thirty commissaries into Belgium, the rear-guard of their army, not "to influence the opinions," but to "supervise the intrigants." commissaries, Pierre Gadolle, "published in November I794 some reflections on the annexation of Belgium."

The professions of the Assembly notwithstanding there existed in France a strong party favoring the extension of France towards her "natural boundaries." "It is necessary to seize the Rhine as barrier," exclaimed Chaussard. ${ }^{87}$ Harou-Romain and Mandrillon considered the Belgians already "as members of the illustrious family comprising the Gauls." 68 Anacharsis Cloots "demonstrated to the Belgians that they would do well to unite with France instead of forming a Belgian republic." ${ }_{60}$ Danton declared "that the

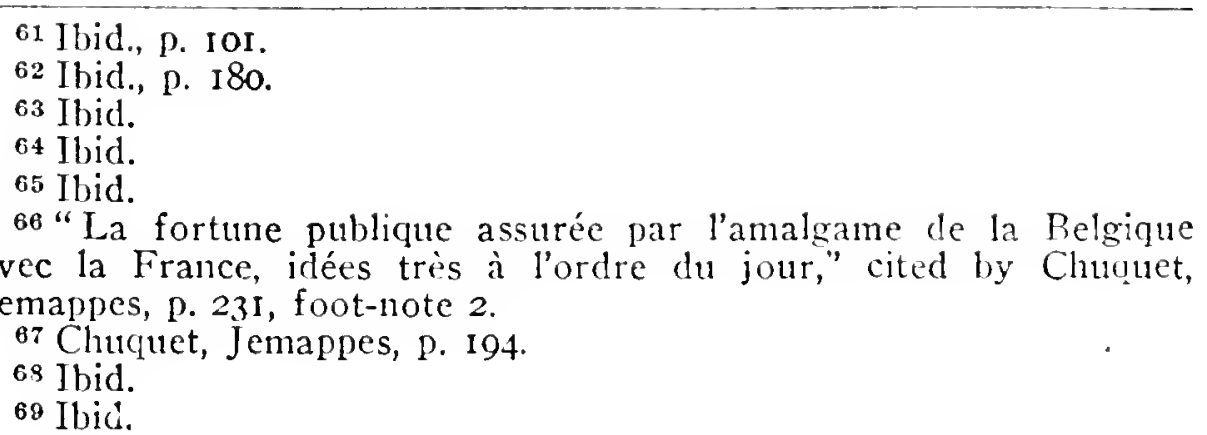


limits of France were marked by nature and that they must be attained by their four points; the ocean, the Rhine, the Alps and the Pyrenees." "An opinion is growing here," writes Bissot to Dumouriez, "that the French Republic must have no boundary short of the Rhine. Are the minds with you disposed to such union? They must be prepared."71 " "We have sworn no conquest,' wrote Grégoire, "but if people, included within the borders of the French Republic, desire political affiliation, must we not receive them?" As Chuquet adds, "Belgium was rich and the fortune of its clergy immense. Why not take hold of those 'gigantic revenues of Flemish superstition' and 'enlarge with it the republican Pactole", ?72 Le Brun, enumerating the advantages of the annexation of Belgium, stated that "France would augment her population by 3 million inhabitants, her army by 40,000 soldiers, her annual revenues by $40,000,000$ pounds, and the mortgage of its assignats more than a billion."73

The Belgians, scenting the danger to their freedom, sent a representation to the Assembly in Paris to demand a solennn declaration "that it did not aim at the union of Belgium with France and that it would not impose on Belgium the assignats." But Le Brun induced the Belgian Commission to omit from their request these two vital points, and Barère let them know the real sentiment of the Assembly when he asked them whether they had not immense treasures which religion for centuries had taken as a deposit for liberty? Arms and assignats, he said, is what an enslaved people needs to break its fetters. ${ }^{74}$

On December I 5, I792, the Assembly adopted the decree which meant the practical annexation of Belgium and

70 Ibid., p. 195.

71 Ibid.

72 Ibid. See also note 102.

73 Cited by Chuquet, Jemappes, p. 195. More expressions for annexation of Belgium are cited, ibid., p. I95 ff.

${ }^{74}$ Cited, ibid., p. I97, from Moniteur, Dec. 6, 1792; see also A. Borgnet, Histoire des Belges, à la fin du XVIII siècle, 2 éd., Bruxelles, Paris, 1861-1862, vol. ii, pp. 90-92. 
the reorganization of the Belgian government after the French pattern. ${ }^{i 5}$ The act caused a stir of resentment and opposition in Belgium where the elections of December 29 practically restored the statists or conservative revolutionists under Vander Noot. ${ }^{\circ 6}$ Chuquet cites a number of protests from Hainaut, Namur, Anvers, Louvain, Malines, Tournésis, Herve, Bruxelles, Liège. Pamphlets against France were circulated in great numbers. "Placards attached to the walls of Malines declared the fatherland in danger and invited the Belgians to unite in order to eject the barbarians who had come to annihilate religion, to destroy the corporations and to impose their assignats." 77 Even Dumouriez, the victor of Jemappes, at first refused to proclaim and execute the objectionable decree. "I shall not be," he wrote, "the Attila, the scourge of Belgium, and I shall not play two conflicting roles in this unhappy country: that of the liberator according to my proclamations and that of the oppressor by the execution of the decree. ..." Bs But the thirty commissioners received their orders in consequence

${ }^{75}$ This decree stipulates that in the countries occupied by French troops, in the name of the French nation the sovereignty of the people be proclaimed; all constituted authorities, all existing duties and contributions, feudalism, etc., to be abolished; the people be assured that France brings them peace, help, etc.; that primary assemblies be convened to create a new government; that all former privileged individuals and officers of state be in this instance excluded from roting; that all property of the former princes, their adherents, of the state treasure, of lay and ecclesiastical bodies and communes be placed under the protection of the French nation. These and various other things being done, the French nation shall, so the decree orders, choose commissaries to be sent to these liberated peoples in order to fraternize with them. Article II reads: "La nation française déclare qu'elle traitera comme ennemi le peuple qui, refusant la liberté et l'égalité, ou y renonçant, voudrait conserver, rappeler on traiter avec le prince et les castes privilégiées; elle promet et s'engage de ne souscrire aucun traité, et de ne poser les armes qu'après l'affermissement' de la souvereigneté et de l'indépendence du peuple sur le territoire duquel les troupes de la République seront entrées, qui aura adopté les principes de l'égalité, et établi un gouvernement libre et populaire." This decree was adopted by the Convention on Dec. 15, I792 (Arch. parl., ser. I, vol. lv, pp. $70-76,100-101)$.

ie Chuquet, Jemappes, pp. 210, 213.

it Only the Province of Liege, not Liège city, and the cities of Mons and Cliarleroi seemed to approve of it (ibid., pp. 200-203).

$$
\text { is Ibid., p. } 206 .
$$


of the act of December I 5 and so, despite all former professions, they set to work to force the Belgian population into formal annexation with France. ${ }^{\text {i }}$

Dumouriez was forced to consent to do what he had at first refused. ${ }^{80}$ The chief tools were the numerous political clubs created and supported by them in the Belgian cities. These clubs did not represent the public opinion of Belgium. ${ }^{81}$ "The democrats who at first frequented them, finally left. In February I793 the Société populaire of Bruxelles counted hardly a dozen Belgians. 'Few citizens,' so the commissioners of the Convention wrote, "dare to belong to the clubs of Louvain, Malines and Anvers:' the Club of Louvain admitted that it consisted of soldiers from the garrison; that of Malines included 92 Frenchmen and Io members from Malines; that of Tournai, yo persons at the most. An agent of the Ministère saw in the Club of Gand only few native born. Frenchmen, civilians and military formed the majority of these clubs; "there are only few popular societies in Westflanders ... and those of the cities are not numerous; almost everywhere officers and French commissaries are at their head. . . ." The patron and protector of the Club of Brussels was General Moreton who ardently approved of the decree of December I5. "Alexandre Courtois was one of the first to demand the conquest of Belgium because France, as he said, must, to maintain herself, aggrandize herself incessantly. Le Brun charged him to establish new clubs, to speak in the popular societies, to publish bulletins for the instruction of the people.... s $^{2}$ On December i8 the Club of Brussels ordered the formation of a legion of sansculottes of Belgium and Liège. The first article of its rules proclaimed all troops of the line or national guards, French as well as Belgian and those of Liège, in law and in fact units of the

79 Ibid., p. 207.

80 Ibid., pp. 204-207.

81 Ibid., p. 214. The following quotations are from the same source, p. $2 \mathrm{I} 5 \mathrm{ff}$., where the original documents are cited.

82 Ibid., pp. $216-218$. 
legion. This legion ruled Brussels by terror. By means of its support the Club resolved to intimidate those protesting against the decree of Deccniber $15 .{ }^{83}$

It was by such means and through these political clubs and popular societies that the Belgian municipal votes for annexation to France were secured. ${ }^{84}$

In the German territories situated to the left of the Rhine, between Landau and Bingen, including Mainz, Worms, and Speier, the spirit of the revolution, fostered by the propaganda of revolutionary clubs like those at work in Belgium ${ }^{\text {s5 }}$ and forcibly encouraged by French occupation, gained sufficient impetus to bring about a separatist movement in favor of annexation to France. ${ }^{80}$ A German imperial order of December I9, I792, "threatened with severe penalties all those who would render the oath of equality and liberty, or who would consent to further the republic. The French countered with a declaration promising fearful reprisals. The oath was to be the prerequisite to the elections and, in order to escape it, the electors took refuge in the German lines." 87 On January $3 \mathrm{I}$ the French Assembly decreed the execution of the law of December I5, wherever French troops entered foreign territory. ${ }^{88}$ The vote in Mayence

83 Ibid., pp. 218-219.

84 For details of the voting, ibid., pp. 22I-223. Complete list in Freudenthal, pp. 6-7; Solière, pp. 66-67; for the text of the French decrees of incorporation see Martens, vol. vi, pp. 432-442. For a detailed account of the annexation of Belgium see also Borgnet.

${ }_{85}$ A. Clutquet, Mayence (Les guerres de la révolution, VII), Paris, n. d., pp. I-45, I08. "Le club des amis de la liberté et de l'égalité établi à Mayence m'a écrit pour m'engager à vous demander si vous voulez accorder votre protection aux Mayençais ou les abandonner à la merci des députés qui les menacent. On leur fait craindre (ce sont les termes de la lettre que j'ai reçue) que les Français ne les abandonnent"; statement made by deputy Rühl to the Convention nationale on Nov. I9, I792 (Arch. parl., ser. I, vol. liii, p. 472). Similar appeals had been made before, one through the good offices of the Amis de la liberté et de l'égalité de Strasbourg, Oct. 29, I792 (ibid., p. I27). This appeal speaks of the delivery of the Mayençais from their tyrants by the citizen general Custine, and asks for the necessary aid to ensure this delivery for the future.

${ }^{86}$ Chuquet, Mayence, p. I ff.

87 Solière, p. 59.

${ }^{88}$ Chuquet, Mayence, p. 83 . See also p. 72 , note 75 . 
began on February 24 , "in the midst of a profound silence, broken only by the sound of the church bells and the patroling cavalry." $\$$ According to Solière only 260 electors appeared. ${ }^{90}$ Another attempt to increase the number of voters succeeded in producing 345 on March $5 .{ }^{91}$ At Worms $25^{\circ}$ and at Speier 342 electors came forth to choose, like those of Mayence, their representatives for the Rhenish Convention. ${ }^{92}$ In these three cities, as in practically all the 125 communities, the population was obdurate and rebellious. Submission was finally achieved only by way of expulsions, arrests and military force. ${ }^{93}$

The Rhenish-Germanic Convention, thus " nominated in a revolutionary manner under the pressure of the sabre and by the minority of the electors," ${ }^{44}$ convened in March I $793,{ }^{95}$ and voted by acclamation the acceptance of the following decree on the 2 rst of March:

The National Rheno-Germanic Convention, considering that the state formed of the territories situated on the left side of the Rhine, between Landau and Bingen, owes its independence, decreed on the I8th of March 1793, to the French Republic and to its victorious arms, that the ties of friendship, of recognition and of reciprocal advantages invite the two nations to a fraternal and indissoluble union, unanimously decrees: that the free Rheno-Germanic people desire the incorporation with the French Republic and that they ask such incorporation; that a deputation be nominated from the body of the National Rheno-Germanic Convention, to make manifest this will to the National Convention of France. . . .96

The following quotation from Chuquet suggests the difficulties that were to be encountered in the enforcement of this decree at home:

While Foster ${ }^{97}$ and his two colleagues hurried on their way to Paris to offer the Rhenish lands to France, the Convention at Mayence, directed by Hofmann, took the most rigorous steps against its

\footnotetext{
89 Ibid., pp. 100-101.

90 Solière, p. 59.

91 Chuquet, Mayence, p. Ior.

92 Ibid., pp. 108-109.

93 Ibid., pp. I03-113.

94 Ibid., p. III.

95 The Assembly consisted of 130 representatives for at least 125

localities (Chuquet, Mayence, pp. III-116).

${ }_{96}$ Chuquet, Mayence, pp. 126-127.

${ }_{97}$ One of the three members of the committee chosen (Chuquet', Mayence, p. 127).
} 
adversaries. Merlin and Reubell had already deported all the monks beyond the Rhine. "The obdurateness is such," said Foster on March I 4 , "that it is necessary to use the most implacable severity; every day there are deported to the other side of the river thirty or forty persons refusing homage; if necessary we shall end by depopulating the city," and he compared the revolution of Mayence to an energetic and violent cure which demands the use of emetics and the resort to amputations.98

A series of decrees were passed against the non-conformists. All who within three days would not render the ath of homage were to be transported with their families. All property of those refusing to render the oath was to be confiscated. All those who had fled since the arrival of the French were declared emigrants. They were ordered to present themselves within three weeks for the oath. Anyone entertaining relations with these emigrants was subject to deportation and confiscation of property. On March 29 another decree ordered all functionaries of the old régime who had not yet rendered the oath, nor intended to render it, to present themselves the next morning at eight o'clock with their families in the place du Château for deportation. Failure to comply was to be punished as espionage and treason. From four to five hundred persons were marched across the bridge to the other side of the Rhine on March $30 .^{90}$

The deductions to be drawn from the preceding survey of the plebiscites of the French revolution are these: The French revolution formulated the doctrine of "no conquests" as a guiding principle for France and for mankind. But " no conquests" was not to imply "no annexations," for soon revolutionary France was to be confronted with the possibility of annexations ${ }^{100}$ which, from a na-

98 lbid., p. I3I.

${ }^{90}$ Ibid., pp. I3I-I33. For the history of the annexations of Miilhausen and Geneva in 1798 see Wambaugh, pp. 55-57, 359-369.

${ }_{100}$ Concerning the annexation of Savoy, M. Grégoire expressed the majority opinion of the French national convention in the following words: "Si des peuples occupant un territoire enclavé dans le notre, ou renfermé dans les bornes posées à la République par les mains de la nature, désirent l'affiliation politique, devons-nous les recevoir? Oui, sans doute; en renonçant au brigandage des con- 
tionalistic point of view, seemed to be fully justifiable. But, in order to annex a territory, formerly in bonds of allegiance to another sovereignty, the former connection had to be broken, if necessary by force of arms. However, to employ arms for a such a purpose would be nothing short of conquest. Hence, in order to divest these annexations of the character of conquest, the principle of popular sovereignty, the alpha and omega of the French Revolution in matters of internal state affairs, was applied to external state relations.

The mental and logical process was simple. The people are the state and the nation; the people are sovereign. As such they have the right to decide, as the ultima ratio, by popular vote and simple majority, all the matters affecting the state and the nation. A people held by force and against their will within the boundaries and under the sovereignty of any state are not in reality a part of that state as a nation. They have, consequently, the right to declare their separation from the dominant state and to proclaim their independence. Having declared their freedom they are themselves a nation and state and as such they are conceded the right to assume a new and different allegiance, where and whenever they wish.

Thus the French Revolution proclaimed the dogma of what we now term national self-determination. It prescribed as the mode of expression of this self-determination the plebiscite ${ }^{101}$ employed in French political life of the past in the form of a more or less restricted expression of opinion or will (voeu), direct or indirect; in feudal times in cases of change of allegiance to liege lord or suzerain, in the election of deputies to the États Généraux, and more

quêtes, nous n'avons pas déclaré que nous repousserions de notre sein des hommes rapprochés de nous par l'affinité des principes et des intérêts et qui, par un choix libre, désireraient s'identifier avec nous" (Arch. parl., ser. I, vol. liii, p. 612).

${ }^{101}$ See case of Nice, where the request for annexation was refused with the advice that it would be accepted only on condition of a popular vote to that effect (above, p. 67). 
recently, for instance, in the remonstrance of the province of Gex in 1776.

Applying the plebiscite thus as a means towards the end sought, that is, the consent of the population of the territory to be annexed, success was possible only if and when the plebiscite produced a good majority in favor, first of separation from the old sovereignty, and secondly in favor of annexation to France. Such a result could of course not always be taken without rumning the risk of jeopardizing the chances of annexation and incurring the odium of conquest; in other cases it was sure to be unlikcly or impossible. Hence one had to resort to friendly advice and gentle persuasion by means of propaganda and promise of military assistance against the former sovereign, or even military pressure against the people to be first freed and then annexed. ${ }^{102}$ Thus the plebiscite, originally purely the means towards the end, became more and more the goal itself. The plebiscite had to be resorted to, for only through it could popular sovereignty, the very basis and comerstone of the revolution, assert itself and make annexation justifiable within the sphere of revolutionary France. ${ }^{103}$ The plebiscite has become the end itsclf and plebiscite and self-determination were henceforth considered as synonyms. By plebiscite, then, was understood, always and never otherwise, a vote favorable to revolutionary France. This being known also to the neighboring states, freed by French troops from their old allegiance, plebiscites were made to order

\footnotetext{
102 Commissary Cliaussard expressed himself to the effect that "le voeu d'un peuple enfant" ou imbécile serait nul, parce qu'il stipulerait contre lui-mème." M. Chépy wanted the annexations of Belgium achieved "par la puissance de la raison, par les touchantes insinuations de la philantropie, de la fraternité, et par tous les moyens de la tactique révolutionnaire," and, so he added, "au cas que nos efforts soient infructueux, et que l'on continue à nous opposer le systeme désespérant de la force d'inertie, j'estime que le droit de conquête, devenu pour la première fois utile au monde et juste, doit faire l'éducation politique du peuple belge" (quoted from Borgnt, vol. ii, p. I94).

103 See note IO1.
} 
by decree of the French Assembly and the National Convention. ${ }^{104}$

The dogma of "no conquests" as applied by France was thus robbed by the French Revolution itself of its bona fide character, and the institution of the plebiscite as a method of expression of the popular will in its determination of sovereignty was killed between its conception and birth. The adoption of both, the dogma of "no conquest" and the principle of the determination of sovereignty by popular vote, by the nations at large, was, at least for the time being, made impossible by the fact that the revolution reestablished the principle of the inviolability of the French territory, imposing the death sentence against anyone considering the cession of French soil, ${ }^{105}$ including, as it did, in French territory all annexations by way of plebiscite. France could annex whatever might be brought to vote for such annexation, but no French territory, once part of France, could ever be disannexed.

France's neighbors and sister states could not recognize the principle of self-determination as conceived and carried into practice by the French Republic without at the same time sanctioning and, in fact, inviting their own dissolution.

104 On January 31, I793, the decree of Dec. 15, I792 (see note 75), was ordered to be enforced in all countries where French troops had entered or would enter in the future (Arch. parl., ser. I, vol. lviii, p. I04).

105 Decreed by unanimous vote Dec. 16, 1792 (Arch. par1., ser. I. vol. lv, p. 79). "La Convention nationale décrète que quiconque proposera ou tentera de rompre l'unité de la République française, ou d'en détacher des parties intégrantes, pour les unir à un territoire étranger, sera puni de mort." A similar decree was passed on April 13, I793 (Arch. parl., ser. I, vol. 1xii, p. 3). 


\section{CHAPTER IV}

\section{Tiie Revival of thie Plebiscite in Italy}

The annexations of the French Republic on the basis of the plebiscite as the expression of the sovereign wili of the people to be thus annexed were, with the exception of a few of the earlier acquisitions of old French enclaves, not of a lasting nature. Most of them were undone by the Peace of Vicnna of 1815 . In the first place, Europe outside of France was still very far from accepting the principle of popular sovereignty, established by revolutionary France, as the fundamental basis of government. In the second place, the states of Europe could not be expected to sanction the doctrine of national self-determination as a means of aggrandizement of another state at their own expense. Hence the plebiscite as the instrument of the doctrine of national self-determination could not be and was not considered as a means of settlement of the territorial reapportionment of Europe by the Congress of Vienna. ${ }^{1}$ There was all the less reason why either the doctrine of national self-determination, or the plebiscite, as its proposed method of procedure, should find favor outside of France, because Imperial France herself had discontinued the practice of

1 The secret gathering of signatures in a part of Savoy in I8I5 can hardly be considered as a qualification to this statement. After Napoleon's abdication Savoy was occupied by the allies, and by the Treaty of May 30, I8I4, was divided between France and Sardinia (Piedmont), having belonged to the latter before annexation to France. In the territory allotted to France, comprising 244 communcs with a population of from $I 68,000$ to I 90,000 , signatures were secretly gathered among the heads of households known to be favorable to a return to Sardinia. Of 31,676 heads of families considered entitled to a signature, 26,439 signed for reunion with Sardinia. The result was transmitted by the Sardinian diplomats to Lonis XVIII, the new king of France, who at once renounced his allotted share of Savoy in favor of Sardinia in a new treaty of Nov. 20, I8I5. For a detailed account see, A. David, Les plébiscites et les cession de territoires, Paris, I9I8, pp. 36-40. 
asking the consent of the many peoples conquered and forced under the French domination of the new empire. The French Revolution had not, as some of the advocates of the plebiscite as the expression of national self-determination are wont to assert, ${ }^{2}$ implanted the plebiscite as an institution in European international life and relations. To M. Talleyrand, the French representative at the Congress of Vienna, Emperor Alexander I of Russia said: "You speak to me all the time of principles, your public law is nothing to me; I know not what it is. What importance do you think I attach to your parchments and treaties?"3 It was more than half a century later that the plebiscite again made its appearance in the international life of Europe.

While the doctrine of national self-determination had ceased to operate with the advent of the French Empire the principle of popular sovereignty, though resented and opposed by governments and rulers, made steady headway in western European national life.

It was in the Italian states that the struggle for recognition of the principle of popular sovereignty found its first successful conclusion. Here, analogous to the French Revolution, was a movement which originated in a revolt against oppressive government and a demand for constitutional reform, into which, in the course of the struggle, were injected questions of the relations to each other of the states involved. This extension and broadening of the revolutionary movement in the Italian states was aimed at nothing less than the abolition of Austrian rule in the two northern provinces of Lombardy and Venetia and the overthrow of the reactionary princes settled upon them by the Congress of Vienna and the Holy Alliance. First as the means to this end and finally as the goal itself, union with Piedmont (or Sardinia) under Charles Albert, the first of all the

2 "C'est de la Révolution française que date la conception subjective de la nationalité, fondée sur le consentement" (David, p. I7). See also Wambaugh, p. I.

3 Rouard de Card, p. 39. 
Italian secular princes to grant liberal reforms of the government and the only one promising national leadership, became the central idea of all revolutionary Italians.

Analogous, also, to the procedure of revolutionary France were the method of expression of the popular will asserting itself in matters of government and the application, as a matter without need of justification, of this method in the termination of their old and the assumption of their new national allegiance.

The efforts of the Holy Alliance to suppress the constitutional and republican tendency of the Italian principalities were marked by decades of autocratic govermment and persecution of all liberal movements, which stirred the Italian patriots to deeds of desperation. Revolution followed revolution, but these outbreaks were local and sporadic and, as a rule, casily suppressed, and the leaders banished or executed.

Soon the revolutinary element realized that only more concerted action could bring success. The banished political writers and poets wrote from France, Switzerland, and England to inspire and edtcate their fellow patriots at home. In an open letter Mazzini appealed to Charles Albert, King of Sardinia (Piedmont) to take the lead in the liberalization and unification of Italy or to acknowledge openly his vassalage to Austria. The young priest Gioberti saw in the Pope the natural leader and hope of a new Italy. With the election of Pious IX in 1846 , Gioberti's dream seemed to materialize. Constitutional reforms were promised and given to the people of the Papal States. Charles Albert, not to be outdone by the Pope, followed suit. In May, 1846 , he showed the courage to antagonize Austria in a quarrel over customs duties. In Tuscany Leopold II was forced to yicld to the popular demand for judicial and administrative reforms in 1847. But Ferdinand II of Naples, who had put down an uprising in Sicily in the year 1837 , still held out. In Modena, Parma, and Piacenza, Austrian infuence and troops were invited to stifle the liberal move- 
ment. In the Austrian subject provinces, the LombardoVenetian states, the iron rule of Metternich tried to stem the popular tide and the growing feeling of national consciousness. ${ }^{4}$

A second revolution in Sicily in January, I848, started the fire which soon swept all Italy. When, with the exception of the resistance of a few strongholds, the revolutionary movement in Sicily had succeeded, Ferdinand, to save his crown, granted a constitution for Naples and Sicily. In February, Charles Albert did the same in Piedmont. The example of Sicily, Naples, and Piedmont, forced the Duke of Tuscany's hand, and soon also the Papal States saw the creation of a lay ministry and the granting of a constitution. Thus, to quote Pietro Orsi, "all Italy, except the territory ruled by Austria, now found itself on the way to freedom."5

But even in the territories ruled by Austria things were stirring. In order to "damage the interests of the Austrian government which possessed a tobacco monopoly," the Lombardo-Venetians banished smoking. To break this selfimposed sacrifice the Austrian military employed force, and a massacre followed in Milan, which set the provinces ablaze. The news of revolutions in France and in Vienna hastened matters. On the I 7 th of March the civil and military governors of Venice were forced to grant the request for a civil guard. In Milan, the capital of Lombardy, the Viceroy was compelled to flee and the Austrian soldiery under Radetzky was expelled by force. On March 22 the Italian "tricolore" was hoisted over Milan. The revolt spread through Lombardy and the Austrian troops had to fall back on the fortresses on the Mincio. Soon Venice ejected the foreigner and instituted a provisional government under Daniel Manin. Other Venetian cities, except

\footnotetext{
4 P. Orsi, Modern Italy, 1748-1898, London, New York, 1900, chapters, vii-ix.

5 Ibid.

6 Ibid., p. I60.
} 
Verona, freed thenselves and joined the govermment of Venice.

The people of Piedmont were highly enthused over the Lombardo-Venetian successes, and began to see in Charles Albert the man destined to free Italy forever from Austrian influence and to unite all Italian provinces under the flag and House of Savoy. He was implored by the populace to send Piedmontese troops to Lombardy and, in fact, Milan asked for his succor. His proclamation "to the people of Lombardy and Venetia" was the reply." "A few days later the Piedmont army crossed the Ticino and triumphantly traversed Lombardy in the direction of the Min/cio." 8

In the general enthusiasm the sentiment for fusion grew rapidly. Plebiscites in Piacenza, Parma and Modena "set the example of immediate annexation with Piedmont."

Venice, under Manin, favored a republican form of govermment and for this reason wavered long, but reverses on the battlefield finally forced the issue. For the sake of protection the Venetian cities of Padua, Vicenza, and Treviso, with the reluctant consent of Venice, decided for annexation to Lombardy. ${ }^{10}$ But at that time annexation to Lombardy meant fusion with Piedmont, since Milan, through a plebiscite, held in the closing days of May, had declared itself for annexation with Piedmont. ${ }^{11}$ A vote taken at the request of Milan in Padua, Vicenza, Treviso, and Rovigo, on June 4, "gave an overwhelming majority for immediate annexation." 12

Still the city of Venice itself held out, until Manin finally sacrificed republican principles for the sake of unity. At first " the government . . . refused to hold a plebiscite, but

\footnotetext{
I Ibid., pp. 168-I69.

8 Ibid., p. I69.

${ }^{9}$ Ibid., p. I79; B. King, A History of Italian Unity, being a Political History of Italy from I8I4-I87I, New York, I899, vol. i, pp. $244,247$.

${ }_{10}$ King, vol. i, p. 246 .

11 Ibid., pp. 243-244.

12 Ibid., p. 246.
} 
it was forced to order the election of an Assembly to decide on the political future of the city [June 3]. The small polls showed the indifference of the masses, and the fusionists carried all before them. . .." ${ }_{13}$ The Assembly convened on July 3 , and "by an almost unanimous vote ... decided for immediate annexation to Piedmont." 14 Bolton King's criticism of some of these plebiscites is rather unfavorable. Referring to the vote in Lombardy, he writes:

Later experience has shown how untrustworthy a plebiscite may be, how with a people untrained in political life a vote on a single issue, taken hurriedly without free and full discussion may be far form representing the real feelings of a people. . . . The republicans, divided and irresolute ... for the most part abstained. Villagers voted under the eyes of the priest, soldiers at their officers' bidding; forgery, pressure, coercion were freely used.

He admits that "the result must have surprised all parties. Five hundred and sixty thousand, or 84 per cent of the electorate, gave their votes, and barely seven hundred were recorded for postponing the question. Making every allowance for the unworthy acts of one party and the disorganization of the other"-so he concludes- "it showed an overwhelming preponderance in favor of fusion." According to King, the plebiscites taken at Parma, Piacenza and Modena showed "majorities proportionately as great.",15

But, "while Charles Albert was collecting votes, Radetzky was collecting men." The campaign went from bad to worse. Milan had to be surrendered, Charles Albert with his beaten army receded to Piedmont, and Venice capitulated in August, 1849 . What the year 1848 had achieved in the way of unity had to be done again more than a decade later in order to attain permanency. ${ }^{18}$

After the termination of the armistice and the defeat of the Piedmontese at Novara in I849, Charles Albert abdicated in favor of his son, Emmanuel II, who concluded

\footnotetext{
13 Ibid., p. 247.

14 Ibid.

15 Ibid., p. 244.

16 Hertslet does not include the official decrees of annexation because "they led to no permanent change in the map of Europe" (vol. ii, p. 1089).
} 
peace with Radetsky, leaving Lombardy and Venetia to the Austrians-for the time being! Under a liberal government Enanucl set about to reorganize the finances, the cconomic condition, and the army of the country, never losing sight of the aims and ideals of his father. At the end of the year 1852 , Cavour became the guiding statesman of Piedmont, and soon succeeded in bringing the subject of Italian unity before the cabincts and councils of Europe. For this the Piedmontese participation in the Crimean war furnished the opportunity.

At the Congress of Paris of 1856 , Cavour "induced the plenipotentiaries of England and France to moot the Italian question at one of their sessions." ${ }^{17}$ Before leaving Paris "Cavour put into the hands of Lord Clarendon and Count Walewski [the French plenipotentiary] a memorial in which, after noting the fact that Austrian opposition had hindered any practical redress of the grievances of Italy, he drew the attention of England and France to the dangers which beset the Kingdon of Sardinia-that kingdom which, alone among the Italian states, had raised an insurmountable barrier to the revolutionary spirit, had kept independent of Austria, and had been as well a counterpoise to the latter's invading influence." ${ }^{18}$ Once more the Italian states began to cast hopeful eyes towards Piedmont. Austria soon saw cause to take notice. Emperor Francis Joseph in the beginning of the year 1857 inatugurated a more liberal policy in the subject provinces which he visited in person. While he was entering Milan, "the municipality of 'Turin [Piedmont] awarded a commanding site on the Piazza Castello for a monument which the Milanese were dedicating to the Sardinian army." At this Austria took offense and severed diplonatic relations with Piedmont. ${ }^{12}$ Cavour succeeded in bringing about an alliance with Louis Napoleon at their meeting in Plombières in 1858 . The following year Austria, alarmed at the nilitary preparations of the Turin

\footnotetext{
17 Orsi, 1). 236.

18 Ibid., p1. $236-238$.

19 Orsi, p. 24 I.
} 
government, strengthened her troops on the Piedmontese frontier and sent an ultimatum demanding immediate disarmanent. The Piedmontese reply was followed by a declaration of war from Austria. The Italians under Emmanuel and their French allies under Napoleon had won decisive victories at Magenta, Melegnano, Solferino, and San Martino, when, on the Sth of July, Napoleon met Francis Joseph and, three days later, signed, unknown to Cavour, the preliminaries of peace at Villafranca. ${ }^{20}$ "Austria was to cede Lombardy to Napoleon who was to relegate it to Piedmont; the Italian states were to be amalgamated into a confederation under the presidency of the Pope, but Venice, though forming part of this same confederation, was to remain under Austrian rule." ${ }^{21}$ Cavour opposed these terms and resigned when Emmanuel affixed his name to the treaty.

Napoleon's sudden desertion of the Piedmontese cause was due to his realization that the Italian states not only desired to free themselves from Austrian interference and sovereignty, but that they wanted unity under the House of Savoy. This he desired to forestall-but in reality could no longer do. "They had already decided to summon a representative Assembly in each state [convened in August and September], and the elections on a restricted franchise in Tuscany and Romagna, on manhood suffrage in Modena and Parma, had everywhere resulted in the triumph of the nationalists. By unanimous votes (only three deputies were absent in Tuscany and one in Romagna) the Assemblies pronounced the downfall of the old governments and the annexation of their states to the kingdom of Victor Emmanuel." ${ }_{22}$ Even the final signing of the Treaty of Zürich on November Io of the same year (I859) between Piedmont and Austria, confirming Napoleon's scheme, did not

20 Orsi, p. 263; Hertslet, vol. ii, pp. 1374-1375. See also final Peace Treaty of Zürich, Nov. Io, Hertslet, vol. ii, pp. I380-I4I3.

21 Orsi, p. 263.

22 King, vol. ii, pp. 96-97; F. A. P. Dupanloup, La souveraineté pontificale, Paris, I860, pp. 370, 377-384; Freudenthal, pp. 9-II ; Stoerk, pp. 125-126. 
deter these states in their clamors for union with Picdmont. But owing to Napolcon's opposition, these plebiscites did not lead to the desired fusion with Piedmont.

In glaring contrast to Orsi's optimistic view and King's more critical but still rather apologetic account of the elections and the Assembly votes of 1859 , stands the scathing arraignment which Dupanloup ${ }^{23}$ gives of the official pressure and coercion under which they were, as he claims, conducted.

Speaking of the vote in Tuscany he cites official figures, supplied by M. Galcotti, Secretary of the Constituent Assembly, showing that "of a population of $\mathrm{I}, 806,740$ souls, only 35.240 electors took part in the vote." quotes Lord Normanby to the effect that even this vote of 35,210 "has been obtained by intimidation, by corruption in all forms," that "these electors up to the last moment knew not the purpose for which they were clecting deputies . . ," that "these deputies did not know wherefore they were convoked and finally were compelled to vote in the name of the nation in a silent meeting, withont debate, without explanation, the forfeiture of the country. . .."25

Dupanloup speaks of the "atrocities committed at Parma, under the eyes of the Sardinian authorities," and offers the testimony of an eye-witness, Mr. Bowyer, an Englishman, to prove that conditions in Romagna were equally as bad as those in Tuscany. In a letter published in the London Times, Bowyer, describing his own experiences, states that " nobody is permitted to read, write, and speak a single word in opposition to the reigning faction and the secret societies. The so-called Parliament of the Romagna does not represent one-sixtieth of the population. The admitted total number of electors is but 18,000 , and of this number, force, intimidation and corruption have not been able to drag even one-third to the polling station." ${ }^{26}$

Referring to the charge made at the time by the Vienna

23 Dupanloup, pp. 377-384.

24 Ibid., pp. 379-380.

25 Ibid., p. 380.

28 Ibid., pp. $381-382$. 
Gazette that in Modena the dictator Louis Farini willfully excluded the rural vote, a charge which "Mr. Farini has not denied," Dupanloup asserts that "in spite of these exclusions ... there remained in the duchy of Modena still 72,000 electors" of whom hardly 4,000 cast their vote. "But," so he asks, "had these 4,000 the right to enslave the will of all the inhabitants of the duchy of Modena?"2z

When, on January I6, I860, Cavour once more accepted the premiership, he "imagined that since Napoleon III had obtained the imperial throne by a plébiscite, he would not deny the validity of such a claim in Italy, and forthwith submitted this idea to the Emperor who was bound to approve of it." ${ }^{28}$ However, Napoleon did not give his consent until, in accordance with the agreement of Plombières, the cession of Savoy, and in addition that of Nice, was guaranteed to France. ${ }^{29}$ French approval having been won, the final plebiscites in Emilia (including Parma, Modena, Romagna, Bologna, etc.), ${ }^{30}$ and Tuscany were held on March II-I2, I 860. "The decree for the plebiscites had given the vote to all males of age; the ballot papers gave the choice of voting for annexation or 'a separate kingdom.' Twenty per cent of the population voted, or about three out of four of those on the register." 31 Public figures gave in Parma: 53,782 for, 165 against ; in Modena : 52,499 for, 56 against ; in Romagna: 200,659 for, 244 against, annexation with Piedmont. ${ }^{32}$ In Tuscany "the autonomists mustered i 5,000 votes out of $386,000 .{ }^{\prime \prime 3}$.

Victor Emmanuel II, having considered " the result of the Universal Suffrage of the Emilian Provinces, proving their unanimous desire to be united to our State" and "having consulted our Ministers," on March I 8 declared these

\footnotetext{
$2 \pi$ Ibid., p. 382 .

28 Orsi, p. 266.

29 Ibid., p. 267 ; King, vol. ii, pp. I I 5-I 16.

${ }^{30} \mathrm{King}$, vol. ii, p. I2I.

31 Ibid.

${ }^{32}$ Stoerk, p. I26; R. von Mohl, Staatsrecht, Völkerrecht und Politik, Tübingen, I $860-1869$, vol. ii, p. 294.

${ }^{33} \mathrm{King}$, vol. ii, p. I2I.
} 
provinces (Bologila, Ferrara, Forli, Massa and Carrara, Nodena, Parma, Placentia, Ravenna and Reggio) "an integral part of the State. ..."3t

In the same manner Tuscany was incorporated in the Kingrdom of Sardinia by royal decree of March $22 .^{35}$

The Duke of Modena, the Duchess of Parma, the Duke of Tuscany, and the Pope, issued official protests against the amnexations of Modena, Parma, Tuscany, and of the Papal Legations of the Romagna. The Duke of Modena protested against "the recent decree of annexation, which it is carefully made to appear as the consequence of a supposed universal voting, and which . . completes the series of unjust and illegal acts by which the sovereignty which we have inherited from our ancestors has been taken from us, after having exercised it for several centuries; sovereignty which . . . was by the Treaty of Vienna of I8I 5 recognized and reinstated in favor of our family by the whole of Europe, happily then coalesced and trimmphant over the revolution," and he is convinced that in so protesting "we are thus performing the duties confided to us by Divine Providence. . . ., 36

The Duke of Tuscany raised his voice "to protest on the Ilullity of the acts consummated by an illegal government; to protest against the consequences which are or may be inferred from those acts by hin who has recognized and reserved our rights by solemn treaties [the Preliminaries of Villafranca, the Treaty of Zürich]": he appealed for "our right to all sovereigns, who must recognize in our cause the interests of their own. . .."

The Duchess of Parma, in behalf of her son, protested "against the pretended right of transfer [dedizionc] proclaimed in favor of the people; a fresh encouragement brought forward for withdrawing them from obedience to constitutional governments; against the proceedings taken

${ }^{34}$ Hertslet, vol. ii, p. I4I6.

35 Ibid., p. I 417.

3r Ibid., pp. I418-I 42 I.

37 Ibid., pp. I $424-1428$. 
by the Government of the King of Sardinia in order to obtain at any cost manifestations in its favour by the inhabitants of the Duchy;... against the annexation of the states of our most beloved son to the dominions of the House of Savoy...., a flagrant violation of European treaties, of all the principles of the Law of Nations, and of the inviolability of States and Crowns." ${ }_{38}$

The Pope protested against "the aggrandizement of Piedmont by the spoils of their [the rebellious central states] legitimate sovereigns" and "in consequence, His Holiness, through the obligations incumbent upon him to preserve and defend the rights of his temporal power, has given orders to the undersigned Cardinal Secretary of State to protest against the accomplished spoliation and violation of the incontestable rights of the Holy See, rights which His Holiness intends to maintain in their integrity; and not recognizing, but, on the contrary, declaring as null, because usurped and illegal, everything that has been done, and may hereafter be done, by Piedmont in the said provinces." ${ }^{\prime 39}$

These protests, however, did not change the course which events had taken nor did they prevent the continuance of the process of annexation of the remaining Italian states and Papal legations.

In the same year the Neapolitans and Sicilians, having, with the aid of Garibaldi, deposed the House of Bourbon, held a plebiscite and, according to Orsi, "thereby unanimously declared their wish to support the monarchy as represented by Victor Emmanuel." ${ }^{40}$ The plebiscite had taken place on October 2r. While "the ballot seems to have been not really secret, and there was no opportunity given to vote for a separate kingdom without the Bourbons," there was at the same time "no open attempt at pressure; in Naples, at all events there was perfect order, and the voting was heavy. ..." "On the mainland I,310,000 voted for

\footnotetext{
${ }^{38}$ Ibid., pp. I $432-1434$.

39 Ibid., pp. 1422-I423.

40 Orsi, p. 282; Hert'slet, vol. ii, pp. I458-1 459.
} 
annexation, and 10,000 against it $;^{41}$ in Sicily 432,000 voted for it, and the opposition shrank to a poor 60o." $* 2$ "A few days later," so King relates, "the plebiscites were held in the Marches and Unbria. In the former the vote for annexation was 133.000 to $\mathrm{I}, 200$, in the latter 97,000 to $3 \mathrm{So}$," and "even the province of Viterbo [in Latium], though reoccupied by French troops, recorded its rote in their despite." 43

By the royal decrees of December I7, r860, the Neapolitan-Sicilian provinces, the Marches, and Umbria were declared integral parts of the Italian state on the strength of "the 'Plebiscito" submitted to universal suffrage in the Neapolitan Provinces convoked in the Comitia on the 2 Ist of October last,... in the Sicilian Provinces convoked in the Comitia on the 2 ist of October last, . . . submitted to universal and direct suffrage in the Provinces of Umbria in the Comitia the $5^{\text {th }}$ of November, . . . in the Provinces of the Marches... the $4^{\text {th }}$ and $5^{\text {th }}$ of November last. ..." 44

However, the Peace Treaty of Zürich had left the Venetian provinces under Austrian rule. Cavour now began to lay his plans for their incorporation in the new Kingdom of Italy. ${ }^{45}$ His idea of an alliance with Prussia ${ }^{46}$ was realized after his death and led to Italy's participation in the war of I 866 . Although Italian arms did not achieve any victories through which Italy could lay claims to the coveted provinces, Austria's defeat at the hands of Prussia was sufficiently effective to secure for Italy the price for which she had given her military aid.

Napoleon, who was asked by Austria to mediate, gladly

${ }^{41}$ King, vol. ii, p. 175; Mohl, vol. ii, p. 294, gives 1,102,499 affirmative and $938 \mathrm{I}$ negative votes for Naples.

${ }^{42}$ King, vol. ii, p. I75.

43 Ibid.

${ }^{44}$ Hertslet, vol. ii, pp. 1458-146r. Hertslet does not include any protests on the part of the former Bourbon rulers of Naples and Sicily, nor a new protest by the Pope.

45 Victor Emmanuel II adopted the title of King of Italy by decree March 17, i861 (Hertslet, vol. ii, p. 1468).

$\$$ Secret treaty signed April 8, I866; see Orsi, p. 303. 
accepted the opportunity in order to secure the cession of Venetia which he had promised Cavour at Plombières in 1858.47 On August II, I866, Napoleon assured the King of Italy that: "My aim is to make Venetia her own arbiter [rendre Vénétie à elle même] so that Italy be free from the Alps to the Adriatic. Mistress of her own destinies, Venetia shall soon be able to express by universal suffrage her own will. . . ." 48

Austria, however, while willing to accede to the cession, was reluctant to deal with Italy directly, especially on the basis of a plebiscite. After protracted discussions between Vienna, Berlin, and Turin, a modus vivendi was suggested by Napoleon. In the treaty of cession Venetia was ceded to France, Austria agreeing to the introduction of the following passage in the Peace Treaty:

His Majesty the Emperor of Austria having ceded to His Majesty the Emperor of the French the Lombardo-Venetian Kingdom, His Majesty the Emperor of the French on his part having declared himself ready to recognize the Union of the said Lombardo-Venetian Kingdom to the States of His Majesty, the King of Italy, with the reservation of the consent of the Populations being duly consulted. . . .49

After the formal transfer of the territories to France, the French General Leboeuf delivered their government into the hands of the city of Venice. The vote in favor of annexation was cast in local assemblies on October $21-22 . .^{50}$

By a royal decree of November 4, it was declared that "in consideration of the result of the popular vote through which the citizens of the freed Italian provinces, called together in the assemblies on October $2 \mathrm{I}$ and 22, have declared their will to be united to the Kingdom of Italy, . . . the Venetian provinces form an integral part of the Kingdom of Italy." ${ }_{51}$

Now, after all the Italian principalities had come into

47 King, vol. ii, pp. 48-49.

48 Moniteur, Sept. I, I866, quoted by Freudenthal, p. 20.

49 Hertslet, vol. iii, p. 1750 .

50 Freudenthal, pp. 2I-22.

51 Ibid., p. 22. 
the fold, united Italy cast her eyes on Rome as the capital of the country.

In opposition to the entire Catholic world, with the nonCatholic states an unknown quantity, and after persuasion had failed to bring the Pope to the point of vielding to the clamor of all Italy, Victor Emmanuel made the most of the favorable conditions offered by France's predicament of I870. "When, after the disaster of Sedan, the Parisian population rose and proclaimed the Republic, the Italian government felt itself absolved from the observance of the agreement made with the French Emperor in $1864 . .$. Victor Emmanuel wrote a letter to Pius IX, in which he implored him, with filial affection, to consider the state of Italy and to renounce the temporal power," but the Pontiff replied that only violence would compel him to yield. ${ }^{52}$ On September 19, I8 7 o, the Italian troops, under General Cadorna, appeared before Rome, and a few days later occupied the Holy City, which now became the Capital of Italy and, in the following summer, the seat of the central government.

However, Italy desired to get another title to Rome than that of conquest. A plebiscite was insisted upon, and when the vote was taken on October 2, it showed 133,68 I votes for annexation and 1.507 against, on a register of 167,548 , and, so King claims, "though probably many of the Papalists were afraid to go to the poll or thought it useless to vote, the figures proved how overwhelmingly Roman feeling was for annextion." ${ }^{53}$

While King cites Cadorna to the effect that the Italian government showed great moderation, ${ }^{54}$ Dupanloup's remarks must once more be noted. "Who does not know," so he asks, referring to this plebiscite in Rome, "that . . . during the elections for the Constituent Assembly, a great number of voters, instead of depositing one ballot in the voting box, threw in as many as thirty, marked with the

52 Orsi, p. 314.

53 King, vol. ii, p. 378 ; Freudenthal, p. 37.

54 King, vol. ii, p. 377. 
names of prostitutes and market girls?... Thus one arrived at the number of votes required to make the election valid." And, so he concludes, "this is the truth about these votes of the Italians, about these popular suffrages which are set as the decisive objection against the right of old sovereigns and as the 'raison dernière et péremptoire' for the annexation to Piedmont."

The description of the voting furnished by the correspondent of the Allgemeine Zeitung, Beilage, no. 282, seems to bear out some of the charges made by Dupanloup. "On twelve places of the city," he wrote, "booths were erected. ... Behind the tables draped in the green, white, and red colours were found several gentlemen acting as the priests of the plebiscite. The sacred ceremony was performed in this manner: One after the other of the voters stepped up from the left, offering to the gentlemen their registration certificate, for which in turn they were given two cards, one with the inscription 'yea,' the other with a 'nay.' The voter then threw the 'yea' card into the voting box on the table, and, leaving by the right, tore the 'nay' card to pieces, accompanying his action with either a crnical grin, dignified disdain, or with a dark mien of rage." ${ }^{56}$

The result of the plebiscite was ratified in the Assembly by a vote of 239 against 20 on December 2I of the same year. ${ }^{57}$

Stoerk denies to these Italian plebiscites a place in the list of international or annexationist plebiscites. "In their true light," he states, "they represent only measures destined to accord to all 'rechtsfähigen' members of the state of a revolutionary population, participation in the essential change of the previously existing government and in the creation of a new constitution of the state." ${ }^{58}$ In an earlier chapter Stoerk had referred to Francis Lieber's identical use of the term international and annexationist

55 Dupanloup, p. 384.

${ }^{56}$ Freudenthal, pp. 37-38.

57 Ibid.

58 Stoerk, p. 126. 
plebiscites. ${ }^{59}$ In this connection it nust be taken into consideration that Stoerk deals primarily only with the plebiscite in the case of annexations, that is annexations by conquest. Inasmucl as these Italian annexations to Sardinia were not conditioned by conquest on the part of Sardinia, but were rather a spontaneous expression of the free will to be thus united, they may, of course, properly be ruled out of Stoerk's consideration. But they fall within the scope of the present wider study as they bear largely upon the future employment of the plebiscite in European politics, especially in so far as Napoleon's apparent and expressed preference for its use is concerned. ${ }^{80}$ One must agree, however, with Stoerk that the plebiscites in these "Italian City States" were indeed superfluous. They were not needed to demonstrate the genuine popular opposition to their foreign princes and of the overwhelming desire of union with Piedmont. "They formed merely the decorative part in the construction of a United Italy and they patently possessed a value only as political manifestations in the face of the desire for intervention by foreign Powers." $" 01$

59 Ibid., p. 40; F. Lieber, De la valeur des plébiscites dans le droit international, in Revue de droit international, vol. iii, pp. I39-145.

60 "I find nothing more honorable than to be the representative of a cause based upon the independence and nationality of a people. Having fought for the independence of Italy, having raised my voice for Polish national existence, I can have no other sentiments, nor follow other principles where Germany is concerned" (quoted by Freudenthal, p. 44).

61 Stoerk, pp. 127-128. 


\section{CHAPTER V.}

\section{The Plebiscite from the Midde of the igth Century}

to the Beginning of the World War

The plebiscites held in the Italian principalities were clearly of a revolutionary nature in so far as they served as the means of carrying into effect the revolutionary movements against the established governments in those provinces in favor of the new allegiances to the Kingdom of Sardinia. That Cavour realized the probability of European opposition to his contemplated annexations on the basis of a revolutionary principle, seems to follow from his attempt to gain the consent of the Emperor of the French by the reminder that it was through the plebiscite that Napoleon had won the imperial crown. ${ }^{1}$ However, in this process of reasoning, Cavour failed to distinguish between the plebiscite in matters internal and in affairs of an international character. It was of this failure that he in turn was reminded by an officially inspired article of the Constitutionnel, of March 30, I860, in which it was made clear that the principle of popular sovereignty could, by false extension, become for Europe the cause of troubles and incessant dangers, that " universal suffrage can be applied only in the interior of a country," and that "it can not serve to modify the exercise of sovereignty in the relations with the outside, nor for an extension of territory." 2 But Napoleon's opposition was not entirely, nor probably even primarily, prompted by an aversion to the principle involved. With him it was a question of practical politics.

Savoy and probably Nice had been the price promised Napoleon by Cavour at Plombières in 1858 for French

1 Orsi, p. 266.

2 Quoted by Solière, p. 5. 
assistance, if out of the impending Austrian settlement, the war of 1859 , a united Italy of eleven million inhabitants, a kingdom from the Alps to the Adriatic, would emerge. ${ }^{3}$ The Piedmontese conception of this kingdom was, of course, one under the House of Savoy. The Treaty of Zürich, enforcing Napoleon's idea to the disappointment of Cavour, provided for an Italian Federation under the "honorary presidency of the Holy Father." " Furthermore, the treaty had left Venetia in the hands of Austria. Thus Sardinia did not consider herself bound to cede Savoy and Nice, nor did Napoleon consider himself justified in demanding their cession.

It was not until the unification of the central provinces with Sardinia had assumed a promising aspect that Cavour finally decided on the great sacrifice of holding out to Napoleon the cession of Savoy and Nice as the bribe for his consent to the violation of the fundamentals of the Peace of Zürich. ${ }^{5}$ When the Italian reluctance to abide by the agreement of Plombières had thus given way, Napoleon experienced no further scruples to consent to still more extended annexations by Sardinia, even though they were based on revolutionary plebiscites.

On the first of March, I860, Napoleon announced to the French Assembly that "in the face of the changes which had taken place in Northern Italy and had given into the hands of a mighty neighbor the passes of the Alps, it had been his duty, in order to make secure the French frontiers, to request the French slopes of the mountains."

The Treaty of cession of March 24. I860, stipulated that "it is understood between their Majesties that the annexation shall be effected without any constraint of the wishes

3 Orsi, p. 267 ; King, vol. ii, pp. 48-49, I1 5-II6.

4 See above. pp. 87-88.

${ }^{5}$ By secret treaty of March 12 he pledged both Savoy and Nice to France to gain Napoleon's consent to the annexation by way of plebiscites of the Central provinces. On March 24 Cavour was forced to sign a public agreement to that effect (King, vol. ii, pp. I20-12I).

${ }^{6}$ Quoted by Freudenthal, p. 7. 
of the populations, and that the governments of the Emperor of the French and of the King of Sardinia will concert as soon as possible upon the best means of appreciating and verifying the manifestations of those wishes."

In his proclamation "to the inhabitants of Savoy and Nice," Victor Emmanuel assured them that while by treaty, concluded on March 24, it had been decided that the union of Savoy and Nice with France should take place with the adherence of the people,-nevertheless "so great a change in the fate [sort] of these provinces should not be imposed on your. It must be the result of your free consent. That is my firm will, that is also the intention of the Emperor of the French. And so that nothing could hinder the free manifestation of your wishes, I recall those of your principal administrative functionaries who do not belong to your lands and I replace them momentarily by several of your own citizens who enjoy general esteem and consideration."s

French troops sent by Napoleon and two Senators, Laity and Pietri, began their propaganda among a populace which, at least in Chablais and Faucigny [Savoy], favored annexation to Switzerland." But "the zeal for secession sank in proportion to the efforts of the French propaganda." 10 According to King, "the majority of the Savoyards indeed were probably more than half disposed to separation, or cared little which way their fate went, though the northern portion of the province would have preferred to be joined to Switzerland," while "at Nice the feeling was strong against separation, and the people made pathetic efforts to escape the destiny imposed upon them." 11

The election returns of the plebiscites held in April showed in Nice 24,637 votes cast of a list of 29, I 42 electors. Of these, 24,448 voted for and 160 against annexa-

7 Hertslet, vol. ii, p. I430.

${ }^{8}$ Quoted by Freudenthal, p. 8.

8 Freudenthal, p. 8.

10 Ibid.

11 King, vol. ii, p. 122. 
tion. In Savoy, with I35.449 electors, I30,533 voted for and 235 against the impending change. ${ }^{12}$

On June 12 a decree of the French Senate proclaimed Savoy and Nice "an integral part of France." 13

The publication of the treaty in the Moniteur was protested by Switzerland on the ground that the "Treaty for the cession of Savoy to France" having "been concluded without the concurrence of Switzerland, which had, however, applied to be allowed to participate in it as one of the principal parties concerned in the negotiations relative to this Cession, this official publication cannot be considered by the Federal Council but as a preliminary act of menace against the rights of which the Confederation is possessed in virtue of former treaties, . . ." and that "a preliminary occupation by foreign agents would be an unfair coercion of the free expression of the wishes of the poptlation of these provinces." 14

The second ground was clearly a protest against the manner in which the expression of free consent was being secured, while the first was tantamount to a charge of violation of past treaties to which, besides France and Sardinia, other signatories were parties. The Powers who had signed the Final Act of the Congress of Vienna and the Declaration of Paris of the 2oth of November, ISI5, had recognized and guaranteed the neutrality of Switzerland and had extended "the neutrality of Switzerland" to part of Savoy (Faucigny, Chablais, and Genevois) forming part of the Kingdom of Sardinia. ${ }^{15}$

The Franco-Sardinian cession treaty of March 24 had taken cognizance of the obligations regarding the neutralized part of Savoy and in Article II had recognized that "the King of Sardinia cannot transfer the neutralized parts of Savoy except on the conditions upon which he himself

12 Ibid.; Freudenthal, p. 9; Stoerk, pp. I29-135.

13 Freudenthal, p. 9.

${ }_{14}$ Hertslet, vol. ii, pp. I435-36.

15 Ibid., vol. i, p. 67, Art. 5 ; p. 262, Art. 92 ; p. 328, Art. 4; pp. $370-371$. 
possesses them, and that it will appertain to His Majesty, the Emperor of the French, to come to an understanding on the subject, both with the Powers represented at the Congress of Vienna, and with the Swiss Confederation, and to give the guarantees required by the stipulations referred to in this Article."16 Prompted by the Swiss protest, Napoleon suggested three proposals for the settlement of the issue of which England officially accepted the first, that of a conference of the interested Powers ${ }^{17}$ to be held in Paris. The proposed conference, however, has never taken place. ${ }^{18}$

It is this first ground of the Swiss protest which explains the wish of part of the Savoyan populace to be annexed not to France, but to Switzerland.

While the French revolutionary plebiscites had led to practically no permanent acquisitions, the unification of Italy was and remained a fact. Furthermore, the accession of Savoy and Nice on the basis of a plebiscite, that is, of national self-determination, was, though challenged, finally acquiesced in by the Powers of Europe. Napoleon III, who had gained the imperial crown through a plebiscite at home, had, by his support of the same institution in the relations of the Italian states, learned to appreciate the value of this instrument for his political ambitions in the affairs of Europe. It was chiefly by his support and insistence that the plebiscite, as the mode of expression of national consciousness and will, was employed in the settlement of matters of international character involving the change of allegiance or determination of sovereignty.

The next important occasion of this kind offered itself in the attempted settlement of the Roumanian question. At the Conference of Vienna, convened on March I5, I 855, to consider the preliminaries to peace between Russia and Turkey and her allies, the Moldo-Valachian question was given a place of prominence for the reason that these

${ }^{16}$ Ibid., vol. ii, p. 1430 .

17 Ibid., vol. ii, pp. I448-1450.

18 Ibid., vol. ii, p. I450, foot-note. 
regions were at the time occupied by some of the Powers concerned and that the settlenent of their future adherence to one or the other of the Powers was considered an important item in their peace program. ${ }^{19}$ The task of finding a solution acceptable to the Great Powers and to the principalities themselves was aggravated by the fact that even the leading men in the Moldavia and the Valachia were not in unison in matters affecting the future of their countries. "Some-the greatest number-desire to maintain the suzerainty of Turkey as a safeguard aginst Russia, other, the more resolute, demand complete independence. Some wish to place themselves under the government of a foreign prince, hoping thus to eliminate internal rivalry and to give greater prestige to the dyuasty, an idea which on the other hand, was repugnant to others or at least seemed to them to be unessential."20 This lack of tmanimity at home was, of course, known at Vienna and was used to good advantage by the opposing parties until finally the only solution promising a way out of the dilemma was the attempt made by one of the French plenipotentiaries, M. de Bourquenay, to force the issue of the unification of the territories to the fore, the only point on which the Roumanian patriots were known to agree. De Bourquenay submitted a protocol of his government on this point on which, however, no action was taken at the time. ${ }^{21}$ The solution of the question was deferred to the final peace conference to be held in the following year at Paris.

At a preliminary conference of Commissioners in Constantinople, Austria submitted a program of government of the principalities. With the support of Turkey the Austrian plan found acceptance in a protocol signed by the parties to the preliminary Conference on February i i.22 The provisions of this plan caused a storm of objections in

${ }^{19}$ J. G. Mano, L'Union des principautés roumaines, Paris, I900, pp. 52-58; N. Jorga, Geschichte des rumänischen Volkes, Gotha, I905, vol. ii, pp. 303-304.

${ }_{20}$ Mano, p. 55.

21 Ibid., pp. 58-6I.

22 Jorga, p. 304; Mano, pp. 79-81. 
Moldavia and they failed to bring about a solution of the question at the final Conference of Paris. ${ }^{23}$ It was at the suggestion and through the influence of the French Government, which owed its existing form to the notorious plebiscite of $185 \mathrm{I}$, that the Paris Conference decided to leave the solution of this vexing question to the wishes of the people concerned. ${ }^{24}$ In Article 24 of the Peace Treaty of March 30, 1856, "His Majesty, the Sultan promises to convoke immediately in each of the two Provinces a Divan ad hoc [a Parliament], composed in such a manner as to represent most closely the interests of all classes of society. These Divans shall be called upon to express the wishes of the people in regard to the definite organization of the Principalities." 25 Strangely enough, the suggestion to submit the issue to a plebiscite was supported by Austria and Turkey, who desired nothing less than to have a vote of the people show their wishes for union. In fact, they hoped to influence, and for a time succeeded in controlling, the vote to such an extent as to present to the Powers a decision favorable to their, the Austro-Turkish, view, which was then also supported by England. ${ }^{28}$ Austrian influence in the coming elections was enhanced by the fact that the Viennese Government had refused to withdraw its troops until the Bessarabian boundary question found a settlement. ${ }^{27}$

A Commission of the Powers was charged to inquire into the actual conditions of the Principalities and to propose a basis for their organization. ${ }^{28}$ The elections were to be held under provisional governments appointed by the Sultan, ${ }^{29}$ and while the outcome of the elections was to be considered by the Commission and the result of its own labor was to be reported without delay for ratification to a new con-

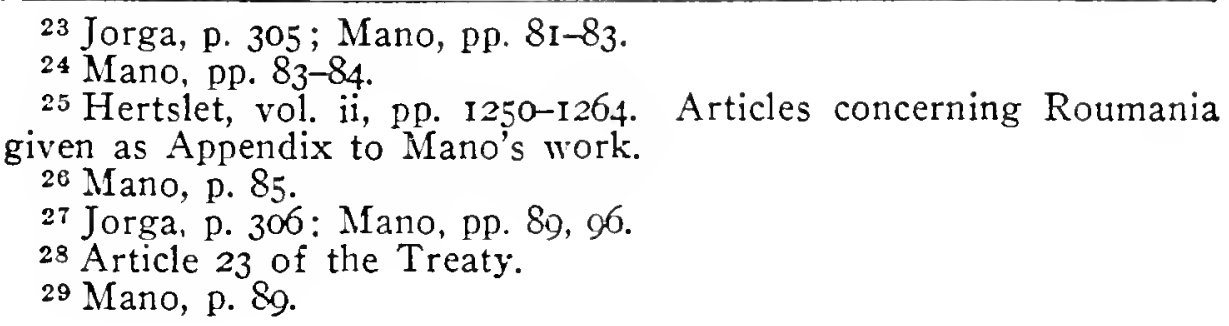


ference to meet once more at Paris, the Commission itself had apparently no authority to concern itself with the actual process of the voting. ${ }^{30}$ Turkey and Austria, with the support of England, centered their obstructive efforts on Moldavia, the smaller of the two countries, where the desired result seemed easier of accomplishment. The description of the election in Moldavia, as given by Jorga and Mano, shows that the Austro-Turkish-English plan succeeded only too well. The freedom of the press was curtailed. Communication by water and by telegraph was interrupted. Intimidations and arrests were not inf requent. Voters favorable to unification were excluded from the election lists. ${ }^{31}$ According to Thouvenel, "nine-tenths of the population were deprived of their right to vote." ${ }^{32}$ Those of an independent mind, who were left on the lists, disdained to register their vote under such humiliating conditions, and thus the election of July, 1857 , brought forth an anti-nationalist and anti-fusion Divan. ${ }^{33}$

Napoleon at once demanded the annulment of these elections. Turkey, however, yielded to this request only when the Emperor of the French had secured the support of Russia and, at a mecting with the Queen of England at Osborne, had overcome the English opposition. ${ }^{34}$ New elections were finally granted by the Sultan, since at Osborne, France and England had consented to limit the extent of the future unity of the Principalities to the "Union des rapports militaires, financiers at judiciaires." ${ }_{35}$ This time the provisional government in Moldavia changed its attitude. The electoral lists were revised, and with these new lists the elections were held without illegal interference on the part of the antagonistic alien forces. "The Moldavian Divan convened the $4^{\text {th }}$ of October [Sept. 22],

${ }^{30}$ Article 25 of the Treaty; Mano, pp. 88, 102-103.

31 Mano, pp. 97-08, 103-106.

32 V. Thouvenel. Trois années de la question d'Orient, Paris, 1897 , p. IIo, quoted by Mano, p. Io6.

33 Jorga, p. 307 ; Mano, p. 107.

34 Jorga, p. 307 ; Mano, pp. 108-III.

35 Ibid. 
I857, amidst the ovations of the population, proud to be called for the first time to make known its wishes." 36

The Divan accepted by a unanimous vote the following five resolutions:

I. The acknowledgment of the rights of the Principalities and particularly the right to their autonomy in accordance with the tenor of their ancient Capitulations concluded with the Sublime Porte in 1393, I511, and I634.

2. The union of the Principalities in one single state with the name Rumania.

3. A foreign hereditary prince, elected from the reigning dynasties of Europe. ...

4. The neutrality of the territory of the Principalities.

5. The legislative power to rest with a General Assembly in which all the interests of the nation are represented. ${ }^{37}$

These same resolutions were adopted by unanimous vote by the Divan of Valachia. ${ }^{38}$

Nevertheless, the Turkish Government declared publicly that "whatever the wishes expressed by the Divans concerning the union of the two principalities might be, the Sublime Porte, resting its case on the text of the Treaty of Paris, felt absolutely obliged to maintain its former decisions, ..." but it manifested its willingness to consent to a unity in administrative legislation compatible with the Sultan's rights. Austria supported the Turkish contention. ${ }^{39}$

The following Conference at Paris found a temporary solution in the creation of the "Principatele-Unite," giving each of the principalities a prince to be elected for life, and both a common central legislative commission of eighteen members to be located at Foscani, situated on the mutual frontier, and a united army and judiciary. ${ }^{40}$

The principle of unity, willed and voiced by the people of Valachia and Moldavia, was thus, at least in part, established. The newly created governments found a way to secure perfect union under the first common prince, Cuza,

36 Mano, pp. III-II3.

37 Ibid., p. II 3 .

38 Ibid., p. I I 4 .

39 Ibid., p. 122.

\$0 Mano, pp. 127-144; Jorga, pp. 310-31 I. 
and independence under their first king, Carol of Hohenzollern Sigmaringen. ${ }^{41}$

The application of the plebiscite in the transfer of territory and its legal status were seriously considered by the leading diplomats of Europe during the discussion of the cession of Northern Schleswig in I864. After the first battles during the war between Denmark, Austria, and Prussia, England suggested a conference which met at London on April 20, I864, with the view to arranging peace between the belligerents. ${ }^{42}$ On May 17 , Denmark refused her consent to a personal union between Schleswig-Holstein and Denmark. ${ }^{43}$ After that the questions before the Conference were:

I. Demarcation of the territory to be ceded.

2. Constitutional organization of the territory to be ceded.

3. Extent to which inhabitants should be granted a voice in the decision of questions one and two. ${ }^{44}$

Point three was suggested by the French representatives and was supported by Bismarck. ${ }^{45}$ Austria was violently opposed to such a revolutionary practice, and so was Russia. $^{40}$ Berlin was not eager to introduce the plebiscite into international affairs, but it saw no reason for opposing

41 Mano, pp. I44-I76; Jorga, pp. 314-379.

42 Freudenthal, p. I3.

43 Ibid. While in personal union with the Crown of Denmark the duchies were to form part of the German Confederation (Freudenthal, p. I5).

44 Stoerk, pp. 136-137; Freudenthal, p. I3.

45 Freudenthal, p. I3. As early as March 20, Napoleon had sent a despatch to London, Berlin and Vienna in which he asked: "What then is more natural in default of a unanimously accepted rule than to take the wishes of the population as a basis?" He concludes: "Tliis measure which conforms to the veritable interests of both parties, it seems to us, is the best suited to lead to an equitable arrangement and to offer guarantees of stability" (quoted by Freudenthal, p. I4, from Staatsarchiv, vol. vi, p. 726). Bismarck replied through the Prussian Ambassador in Paris, on April I4, that Prussia would support the French plan. But he advised that the plebiscite be deferred until the inhabitants were placed in a position to see that the clioice of the House of Augustenburg would be impossible and that the question for them to decide would be, Danish or Prussian. This suggestion prevailed (Freudenthal, p. I5).

${ }^{46}$ Freudenthal, p. I4. 
France and was, therefore, willing to discuss the matter. ${ }^{47}$ As to point one, Prussia and Austria considered the more northern line of Apenrade-Tondern, Denmark the more southern line of Eckernförde and the river Schlei as the line of demarkation between the German and the Danish sections of Schleswig. ${ }^{48}$ France and England, with the approval of Prussia, were willing to let the population decide this question. Austria and Russia were opposed to popular decisions on principle. Denmark opposed a plebiscite in the assuredly Danish sections. France modified its request for a plebiscite, to the effect that it be used, not to settle the boundary, but to decide the choice of sovereign by the section of the territory to be ceded by Denmark. ${ }^{49}$ Finally, in order to prevent the failure of the Conference, France revived its original plan of holding a plebiscite in the sections between the Eckernförde and Apenrade lines in the following form:

It has not been found useful to make an appeal to the wishes of the population where these wishes seemed manifest, but one could consult the populations where the wishes are doubtful. . . . In order to secure desirable guarantees it would be useful that all military force be first eliminated and that the voting take place free from all pressure. ${ }^{50}$

The Conference disbanded on June 25, I864, without agreement, and the decision was left to arms. By the Austro-Prussian-Danish Treaty of October 30 of the same year, Schleswig-Holstein and Lauenburg ceased to be under Danish sovereignty and came into joint ownership of Austria and Prussia. The right of option was extended over

47 Ibid., pp. 14-I5.

48 Ibid., pp. I 5-I7.

49 Ibid., pp. I6-17.

50 Ibid., p. I9. Bismarck agreed that the plebiscite in the sections to be ceded was to decide neither the boundary nor the choice of ruler, but should merely show whether the people living between the northern line claimed by Austria and Prussia and the southern line demanded by Denmark cherished German or Danish national sentiment. The final decision would be made by the Conference, not by the people voting (Freudenthal, p. 17). Austria protested against any plebiscite whatsoever; Denmark objected that the plebiscite should be held only in the future German section, not in the Danish territory (Freudenthal, p. I8). 
six years. In the Convention of Gastein of August I4, I865, Lanenburg was definitely given to Prussia. While the joint ownership rights over Schleswig-Holstein remained in force, the government of Holstein was assigned to Austria, and that of Schleswig to Prussia. ${ }^{51}$

The question of a plebiscite in Northern Schleswig was revived in the settlement of 1866 at the end of the AustroPrussian war. After military victory of the Prussian army was established, Napoleon was asked by Austria to mediate. He suggested that "the duchies of the Elbe be united with Prussia, except the districts of the north of Schleswig where the populations freely consulted, might wish [desircraicnt] to be retroceded to Denmark." ${ }_{52}$ This suggestion was agreed to by Bismarck and was in principle incorporated as Article III in the Preliminary Peace of Nikolsburg, and on August 23 as Article $V$ in the Peace Treaty of Prague. ${ }^{53}$

Denmark, hoping to regain part of her lost territory, was now in favor of the plebiscite in those sections. Prussia, however, did not wish to retrocede any part of Schleswig. The Peace Treaty of Pragne was referred for ratification to the Prussian Landtag, and a commission of thirteen was appointed to consider whether and how far the question of the plebiscite in northern Schleswig was compatible with Prussia's interests. The Commission received fifty petitions with 5,I39 signatures from forty-seven communities of Schleswig-Holstein opposing annexation without the consent of a representative Assembly. A petition from the Citizens Union of Apenrade with twelve signatures and a petition of twelve citizens of northern Schleswig domiciled in Hamburg demanded annexation of all of SchleswigHolstein. ${ }^{54}$ Several members of the Commission favored, with the petitioners of the forty-seven communities, a plebi-

51 Stoerk, pp. 140-142.

${ }^{52}$ Freudenthal, p. 22.

53 Ibid., pp. 22-23; Hertslet, vol. iii, pp. 1698-1701, 1720-1728.

54 Freudenthal, pp. 25-26. 
scite of the entire provinces. But the final report recommended that the vote be restricted to the most northern parts of the section whose retrocession was in question, or the elimination of Article $\mathrm{V}$ from the Peace Treaty altogether. ${ }^{55}$ During the discussions of December 20, Bismarck announced that Article $\mathrm{V}$ was incorporated in the Peace Treaty under pressure from France. Since it was there, it could and should not be ignored, but "the obligations imposed will be carried out by us in a manner that will leave no doubt about the voting, ... its spontaneity and independence, and about the definite will expressed." ${ }^{6} 6$

Nevertheless, on December 24, 1866, the annexation of all of Schleswig-Holstein was ratified. The exchanges of notes between Denmark and Prussia continued without result. ${ }^{57}$

Austria, in disregard of her former opposition to the plebiscite, at first stood out for the fulfilment of Article V, and on March 28, 1867, expressed her wish in this respect. ${ }^{58}$ But on April I, I868, the Austrian Government instructed its representative in Berlin to the effect that "regardless of the incorporation of the Prussian promise of retrocession, in the Peace Treaty of Prague we harbor no desire to intervene in this matter. . . "s9 Bismarck in the North German Reichstag had insisted that Prussia's obligation for the fulfilment of Article $\mathrm{V}$ was one towards Austria and that no one but Austria was entitled to demand the fulfilment of that obligation, since the two were the parties who had con-

55 Ibid., p. 27.

56 Quoted by Freudenthal, p. 28. On Sept. 24, 1867, Bismarck had declared in the Reichstag: "If all Danes lived in a district on the Danish frontier and all Germans on this side of it I would consider it as wrong policy not to solve this matter with one stroke by the return of this district to Denmark. I would consider this return as a plain requisite of the same national policy which we follow in Germany. But with the mixed population the difficulty of the question is that we cannot give Danes to Denmark without giving Germans at the same time" (quoted by Stoerk, pp. 143-144).

${ }^{57}$ Freudenthal, pp. 28-30.

${ }^{58}$ Ibid., pp. 30-3I.

59 Ibid., p. 33 . 
tracted the Peace of Prague ${ }^{00}$ Finally, these two parties by the Treaty of October I I, I878, abrogated Article V. ${ }^{61}$

The unification of Italy had given Napoleon the occasion to acquire Savoy and Nice in order to obtain for France security of its boundaries. The same motive in 1867 , on the occasion of the formation of the North German Federation, prompted the French desire to secure the annexation of Luxemburg ${ }^{62}$ again, of course, on the basis of self-determination.

The principle of popular consent was stressed in a statement to the French Parliament after the North German Reichstag had opposed the acquisition of Luxemburg by France. Moustier told the Assembly that France would consider the acquisition only if, aside from other considerations, the population of Luxemburg should express their wishes to that effect by universal suffrage. ${ }^{63}$ An appeal from Luxemburg read by Benningsen in the North German Reichstag in April seemed to indicate that the people of Luxemburg, despite their French sympathies, preferred Prussia to France. "If it were not too openly whispered," so the passage in question read, "that by secret agreement we have long been given up by Prussia, you could be assured that there would be no lack of popular expression of our sentiments. In case of a plebiscite, a somewhat certain expectation of a treaty, in any way acceptable, with Prussia would suffice to insure everywhere a vote favorable to the German cause." 64

However, no agreement between Prussia, France, and Holland could be secured, and the Luxemburg question was solved at the Conference of London without a plebiscite. ${ }^{65}$.

Notwithstanding the consistent opposition of both England and Germany to the principle of national self-determi-

60 Ibid, p. 32.

61 'Text quoted by Freudenthal, pp. 34-35.

62 Freudenthal, pp. 35-36.

B3 Ibid., p. 36.

${ }^{64}$ Quoted by Freudenthal, p. 36, from Staatsarchiv, vol. xiii, p. 29.

65 Freudenthal, p. 36. 
nation in international relations, the plebiscite was proposed in the case of the cession of Heligoland by England in I89o, the Daily Nere's and the Pall Mall Gazette coming out as the most ardent advocates of its application in the island to be transferred. ${ }^{66}$

Prior to the introduction of the bill of cession, various inquiries were made in Parliament as to whether the proposed agreement of cession had taken into account the willingness, or unwillingness, of the people of Heligoland to be transferred from English to German sovereignty. In answer to a question to that effect, put in the House of Lords by the Earl of Rosebery on June 19, I890, the Prime Minister and Secretary of State for Foreign Affairs, the Marquis of Salisbury, replied:

My answer must be in the negative. The plébiscite is not among the traditions of this country. We have not taken a plébiscite; and I see no necessity for doing so. At the same time, we have good ground for believing that if there has been expressed in past times any objection on the part of any of the inhabitants of Heligoland to this transfer, it has been mainly connected with the fear of a conscription; and if the noble Earl will read the Despatch which has been laid upon the Table he will observe that we have taken the precaution to stipulate that no person alive at the time of the cession shall be subject to obligatory military or naval service. . . ${ }^{67}$

During the second reading the Prime Minister opposed the plebiscite as out of the question. To give people the right to decide whether they wish to be ceded would entail the right to express the reason why they might not wish to be ceded. ${ }^{68}$ Lord Rosebery opposed the transfer of two thousand souls without their consent, reminding Lord Salisbury, who was the sponsor of the cession plan, that he (Salisbury) himself certainly would not cherish the idea of being arbitrarily transferred to another Power. ${ }^{69}$

66 Ibid., p. 39.

67 Hansard's Parliamentary Debates, vol. 345, cols. 13II-I312. In this connection see also ibid., cols, I368-1369, I482, 1656-1657, I796; vol. 346 , cols. $303-307,456-457$. The Marquis of Salisbury suggested that "it may, perhaps, have occurred to the noble Earl [of Rosebery] that a plébiscite might be an awkward precedent as applied to other parts of the Empire" (ibid., vol. 346 , col. 305 ).

68 Ibid., vol. 346 , col. 1263.

69 Ibid., col. I 275. 
In the Lower House Gladstone was not in favor of the plebiscite. A handful of British opinions of private individuals should not be set against the conclusions of the government. ${ }^{70}$

Before the passing of the bill MacNeil, Dr. Tanner, Channing, N'Arthur, and Picton favored the plebiscite. They were opposed by Labouchère, who pointed out that the cession of Heligoland was only part of a great treaty whose acceptance or rejection, as Sir James Ferguson, Under-Secretary of State, added, should not be made dependent upon the consent of the people of Heligoland. By a vote of 172 against 76 the demand for a plebiscite was defeated. ${ }^{11}$

The plebiscite which ended the Swedish-Norwegian controversy and led to the separation of the dual monarchy through the establishment of the Norwegian kingdom, is stili too fresh in the memory of the present generation to require a detailed introduction. ${ }^{72}$

On June 7, Ig04, the Norwegian Storthing declared that "the Union with Sweden ... is dissolved." The declaraticn was embodied in an address to be delivered to King Oscar, who refused to receive any deputation from the revolutionary Storthing. ${ }^{73}$

The Swedish attitude to the fait accompli is laid down in an address delivered to the King by the Swedish Riksdag called in special session. The address states that "by the

${ }^{70}$ Ibid., vol. 347, col. 756. During the Franco-Prussian War of I870-I87I, Gladstone had advocated the consultation of the population of Alsace-Lorraine in the matter of the latter's cession by France to Germany. See below, pp. I74-175.

${ }^{71}$ Freudenthal, pp. 40-4I. See also Hansard's Debates, vol. 347. An outline of the treaty of ccssion is found in the Annual Register for 1890, pp. 322-323.

i2 For a detailed account see K. Nordlund, The Swedish-Norwegian Union Crisis, A History with Documents, Upsala \& Stockholm, 1905; N. Edén, Sweden for Peace, The Programme of Sweden in the Union Crisis, Upsala \& Stockholm, I905; L. Jordan, La séparation de la Suède et de la Norvège, Paris, I906: K. Gjerset, History of the Norwegian People, New York, 1915; The Annual Register, 1905, po. 359-367.

${ }^{73}$ Nordlund, pp. 60, 99-Ior ; Annual Register for I905, pp. 365-366. 
declaration of the Storthing the Union is not dissolved," and that "it can not be dissolved without the consent of the King and Swedish Riksdag. . .."74 The Riksdag's statement is thus commented on by $\mathrm{K}$. Nordlund:

This does not mean that Sweden will refuse her consent; but it does mean that Sweden can and will demand that her just claims shall be fulfilled before the dissolution will obtain international recognition. Sweden demands a real settlement with Norway. The first condition for such a settlement is that Norway makes a formal request to Sweden for the desired solution. If, however, this request shall be accepted as the uncontested expression of the will of the Norwegian people, it must not be made until that people explicitly has made its will known either through new elections to the Storthing or by means of a referendum. ${ }^{75}$

A special committee was appointed by the Swedish Government to consider the question of dissolution. This Committee reported on July 25 that "Norway should present a formal request after a new Storthing had been elected, and after the Norwegian people through a plebiscite should signify their desire for the dissolution of the Union. If these conditions were complied with, negotiations might be entered into for the arrangement of terms, on which the final agreement might be based." The report was adopted by the Swedish Riksdag. ${ }^{76}$

On August I3, the Norwegian people were given an opportunity to express by a plebiscite or referendum their opinion on the question of separation as voted by the Storthing on June 7 . "The notice given was very brief, and many sailors and fishermen could not reach home in so short a time. But of the 435,576 voters in the Kingdom, 37 I,9 I I, or 85 per cent, were able to cast their ballots. Of these, 368,208 voted in favor of the dissolution of the union, and I 84 against it. 3,5 I9 ballots were discarded." 77

Gjerset's comment that "never has a nation expressed a more unanimous opinion on a public question," and that "never has a people made a more determined effort to be

\footnotetext{
${ }^{74}$ Edén, p. 23.

75 Ibid.

${ }^{76}$ Gjerset, pp. 58I-582.

77 Ibid., p. 582 ; Annual Register for 1905, p. 366. 
present at the polls,"is is apparently fully justified. Even the Swedish Government at the time recognized and appreciated the almost entire absence of an opposing minority. In the Riksdag's address to the King it was admitted that this condition, a Norwegian referendum, was a reality, and a tremendous majority of votes, in fact almost all, had been given for dissolution. In answer to those European papers which hinted at Swedish disappointments as the result of the Norwegian plebiscite, the Riksdag stated in effect, as summarized by Edén, that "in itself this Norwegian unanimity is a relief to us," and that "if the Union is to be dissolved, nothing would have made a settlement more difficult than a strong Norwegian minority against such a solution." ${ }^{2}$

A few minor cases of territorial cession on the principle of national self-determination expressed by direct or indirect vote, require mention for the sake of record rather than on account of their importance.

The national spirit which was active in the unification of Italy found its echo in Greece. The year 1854 saw the Greeks rise once more in the attempt to secure for Greece, if possible, the lands and islets which once had belonged to her. This new spirit reacted upon the peoples of the Ionian Islands, then under the protectorate of England. ${ }^{80}$ "When the Greek Kingdom became a recognized state of Europe, the wish to be politically united with men of their own race took root among the people of the Ionian Islands." ${ }_{\mathrm{s} 1}$ In addresses and public meetings the peoples gave expression to their wishes. Finally Sir John Young, the English High Commissioner, suggested to the Home Government that the Islands be ceded to Greece. Gladstone went in person to investigate the sentiment of the population and was overwhelmed with petitions. ${ }^{82}$ On June 27,1859 , the Ionian

78 Gjerset, p. 582.

${ }^{79}$ Edén, pp. 23-24.

80 Freudenthal, pp. II-I2

${ }^{81}$ Quoted by Freudenthal, p. I2, from Russel's Circular Note of June Io, I 863.

82 Freudenthal, p. I2. 
Assembly had declared unanimously for union with Greece, and it repeated its declaration when, on June 14, 1861, Miaulis in the Greek Chamber assured the Islands that hardly anybody in Greece was opposed to the union. On the occasion of the second vote it was decided to send a copy of its declaration of June 27, I859, to the British Government and to the other Great Powers. On October 5, I86I, the Ionian Parliament once more voted for annexation to Greece. When Austria, France, Prussia, and Russia, through the Treaty of London of November, 1863, had agreed to the union, England relinquished her protectorate in favor of annexation to Greece. ${ }^{83}$

St. Bartholomew, together with a group of ten smaller islets of the Lesser Antilles, were added to the colonial possessions of France in the year 1058 by order of $M$. Poincy, Governor of the Island of St. Christophe, under the ministry of Mazarin. ${ }^{84}$ The Island was ceded to Sweden in 1784 in consideration of trade concessions in favor of France $^{85}$ and was retroceded to France by sale for the amount of 400,000 francs in the Treaty of August I0, 1877. But in this treaty both Sweden and France agreed to secure the sanction of the populace to the act of transfer.

83 Ibid. Freudenthal, p. II, note 3, and Stoerk, p. 135, maintain that the case of the Ionian Islands has only an "äusserlichen Zusammenhang" with the scope of the subject because (I) the cession was not a real change of territorial scvereignty, but merely the termination of a protectorate; (2) the people did not hold a plebiscite, but the issue was decided in Parliament. In this connection see also the case of the Island of Crete, where several assembly votes in favor of union with Greece took place between 1906 and I9I2. At that time Crete was still under Turkish sovereignty, though under the protection of four of the Great Powers. A popular uprising in March, 19I2, overthrew the government forced upon the Cretons by the protecting Powers and set up a provisional government of their own choosing, "the reception of whose delegates at Athens in October, IgI2, was one of the excuses for the outbreak of the Balkan War." The union of Crete with Greece was recognized by the Treaty of Bucharest of August I0, I913 (Wambaugh, p. 20; The New International Encyclopadia, Crete).

${ }^{84} \mathrm{E}$. Plauchut, L'Annexion de l'île Saint-Barthélemy, in Revue des deux mondes, r879, vol. xxxii, p. 422.

85 Ibid., p. 428. 
Article I of the agreement stipulated that:

"Sa Majesté le Roi de Suède et de Norvège rétrocède à la France l'île de Saint-Barthélemy. . . . Cette rétrocession est faite sous la reserve expresse du consentement de la population de Saint-Barthélemy et, en outre, aux conditions cmumérées dans un protocol special." ${ }^{6}$

By a vote of 350 against a few absentees the population declared for retrocession to France. ${ }^{87}$ Whercupon the people of the island were declared to be subjects of France in a Protocol of October 30, "ayant été consulté conformément à l'article $I^{\text {er }}$ de la convention en faveur d'une réunion de cette île aux possessions françaises." 98

In his article on the annexation of the Island of St. Bartholomew to France, E. Plauchut rejoices that the retrocession to its former owners was not achieved by war and bloody reprisals, but he regrets that the transaction had been accomplished in a manner similar to the inclusion in the budget of the purchase of a "tableau" or "some war material" without having been accorded even a short but dignified discussion in the Senate or the House of Deputies. $^{89}$ Of the principle of popular consent to be applied as it was he makes light, when he writes:

To vote for their municipal councilors, their deputies or senators, certainly means a great deal in France, but under the equator at Guadeloupe, Martinique, Derisade and soon in St. Bartholomew, is less important. In those regions only so-called colored people are occupied with politics; the pure white and the negroes abstain, the former because they are to-day in the minority, the latter because they know no other politics than to live without work. ${ }^{90}$

There have been various instances of a resort to the plebiscite in the case of territorial changes in the history of the United States, and one in the international settlement of some of the South American countries.

\footnotetext{
${ }^{86}$ Freudenthal, pp. 38-39.

87 Plauchut, p. 430. The absentees were mainly Lutherans of Swedish nationality. "Four hundred English Methodists chose for France" (ibid.). See also Wambaugh, pp. 155-I56.

s8 Frcudentlial, p. 39.

89 Plauchut, p. 417.

90 Ibid., p. 432. The cliefs of Tahiti (Society Islands) were consulted regarding the treaty of cession of the island to France in I880 (Wambaugh, p. 23).
} 
With the successful conclusion of the Revolutionary War the selection of a federal capital became imminent. The central points of the thirteen states were in Maryland and Viriginia. In March, I783, New York tendered Kingston; in May, Maryland urged the choice of Annapolis; in June, New Jersey offered a district below the falls of the Delaware. Virginia, having Georgetown for its object, invited Maryland to join in a cession of equal portions of territory lying together on the Potomac; leaving Congress to fix its residence on either side." ${ }_{91}$ The following year a Congressional Committee reported in favor of the location on which Washington now stands and the offers made by Maryland and Virginia were accepted..$^{92}$ But on September 7,1846 , that part of the District derived from Virginia was retroceded to the Old Dominion upon a petition of its occupants, by a vote of 763 to $222 .^{93}$

In the United States the next occasion for the change of territorial inter-state relations by popular decision came with the issues involved in the slave question and their aftermath, the Civil War.

On the Ioth of December of the year I 860 , the Legislature of the State of Louisiana met and passed a bill authorizing a convention, to be held on January 23 of the following year with the object of considering the question of secession. On January 25, that body passed an ordinance of secession by II 3 yeas and I7 nays. A motion to submit the ordinance to a popular decision, a plebiscite, was defeated by a vote of $S_{4}$ against $45 .{ }^{94}$ The secession ordinance

${ }^{91} \mathrm{G}$. Bancroft, History of the United States of America, the author's last revision, New York, 1885, vol. vi, pp. 97-98.

92 Ibid., p. 98.

93 W. F. Dodd, The Government of the District of Columbia, Washington, 1909, p. 32. See also The Encyclopedia Americana, District of Columbia.

${ }_{94} \mathrm{E}$. McPherson, The Political History of the United States of America during the Rebellion, Washington, D. C., I864, pp. 3-4. A widely held doctrine of American constitutional theory is to the effect that a constitutional convention is to be construed as representing the entire people in their original sovereign capacity and that, therefore, a vote of such a body is to be deemed equivalent to a 
was passed in Alabama in secret session, veas 6r, nays 39, but the proposition to submit the ordinance to the people was lost by a vote of 53 to $47 .^{95}$

In Texas the ordinance of secession passed by a vote of I66 to 7 and, when actually submitted to the people, was, on the 23 rd of February, I86I, approved by 34,794 votes for and II,235 against the neasure. ${ }^{96}$

In Arkansas an act calling for a state convention was passed the Legislature on January I6, I86I. The popular vote on the question of calling the convention was, 27.412 for, and 15,826 against it. The convention met on March 4. On the I8th of March the ordinance of secession was rejected by a vote of yeas 35 , nays 39 . It was then agreed to submit the question of secession to the vote of the people on the first Monday in August. But before that day arrived the convention reconsidered its former action and on May 6 passed the ordinance by yeas 69 , nays $1 .{ }^{97}$

The North Carolina Legislature passed a bill for a state convention on January 30, IS6I. This bill provided that no secession movement would be valid unless adopted by referendum. On February 28, the election of the delegates to the convention took place. The rote was against the calling of a convention by a majority of 662. However, the Governor, favoring the secession of the State, called the Legislature in extra session. On May $\mathrm{I}$, the latter voted for another election of delegates to a second state convention. The election took place on the $13^{\text {th }}$ and the delegates convened at Raleigh on the 2oth. On the following day the secession ordinance was adopted and the Confederate Con-

direct vote of the electorate, that is to say, a plebiscite. In this connection see Roger S. Hoar, Constitutional Conventions, Their Nature, Powers, and Limitations, Boston, I917, especially chapters iv, $x$, and $x i$.

9: Ibid., p. 4. The secession ordinances in South Carolina, Georgia, Mississippi, and Florida were passed in state conventions convened by special elections to consider the question of secession. There was no popular ratification of the ordinances by referendum in these states (ibid., pp. 2-4).

96 Ibid., p. 4.

97 ibir. 
stitution was ratified. No further referendum on the secession ordinances was held, notwithstanding the fact that the bill of January 30 had provided that no secession movement would be valid unless approved by popular majority vote. ${ }^{98}$

The first popular vote in Tennessee decided against the holding of a state convention by a poll of 67,360 to $54, \mathrm{I} 56$. But on May I the Legislature " passed a joint resolution authorizing the Governor to appoint Commissioners to enter into a military league with the authorities of the "Confederate' States." The declaration of independence, passed on May 6, was submitted to the vote of the people on June 8. Governor Harris declared Tennessee out of the Union, the popular vote resulting in 104,019 for, and 47,238 against the measure. ${ }^{99}$

While the secession ordinances had been voted upon and had been accepted without great opposition in the legislatures of most of the seceding States, and had been approved by popular referendum in Texas and Tennessee, matters moved more slowly in Virginia, where, when they were finally brought to a head, they ended in the division of the State. ${ }^{100}$

"Unequal representation of the counties" as "established in the year I66I, by the House of Burgesses," and "iimitation of suffrage to freeholders . . . imposed on the Colony in I677, by Royal instruction from Charles II, to the Governor of the Colony of Virginia "to take care that the members of the Assembly be elected only by freeholders, as being more agreeable to the customs of England," "had long ago set the counties east and west of the Blue Ridge Mountains in opposition to each other. "With the increase of the population and the organization of counties west of the

98 Ibid., pp. 4-5.

99 Ibid., p. 5 .

100 The following outline is based on V. A. Lewis' History of West Virginia, Philadelphia, IS89, chapters $x x-x x v ;$ Appleton's American Annual Cyclonædia and Register of Important Events of the year I86I, Virginia, and Virginia, Western; McPherson, pp. 5-8. Quotations, unless otherwise stated, are from Lewis. 
Blue Ridge . . many of the western counties paid into the public treasury many times the amount paid by some of the Eastern counties, yet the representation of both was the same. . . It was . . 'taxation without representation." In the Assembly of 1820 , the East had one hundred and twenty-four members, while the West had but eighty. The result was "that the East secured to itself ncarly everything in the character of internal improvement," while the representatives of the western counties were glad to return home with a "few hundred dollars to be used in the construction of a mud turnpike." What caused the greatest dissatisfaction, however, was the fact that the right of suffrage was restricted, by means of property qualifications, to freeholders, so that in the war with England "thousands marched to the field, who were treated as aliens in the land of their nativity, and that, too, by the very government they were giving their lives to defend." After much opposition a bill was finally passed in the Assembly at the session of 1827 I828, providing for a public vote on the question of calling a constitutional convention to revise the old instrument of 1776 . In 1828 the poll registered 21,896 for and 16,646 against the proposition. During the session of this Convention held in October, I829, in Richmond, the breach between the East and the West widened. When the final vote on the new constitution was taken, every delegate from the counties west of the Alleghenies, except one who was absent owing to illness, voted against it, while all others voted aye -and that for the simple reason that the new constitution secured none of the reforms sought, that it still restricted the right of suffrage and still denied to the West equal representation. When the new constitution was submitted to popular vote, "every county east of the Blue Ridge with one exception (Warwick), gave a majority for ratification; while every county in what is now West Virginia, with two exceptions (Jefferson and Hampshire), voted largely in favor of rejection," and "of the total vote $(9.758)$ cast in these [western] counties, 8,375 were for rejection." Thus 
the "new constitution went into effect, and under it was added to the evils of the old political ostracism in the West." During a quarter of a century, Lewis writes, "but one man-General Andrew Moore, of Rockbridge-had ever been chosen from a county west of the Blue Ridge to represent Virginia in the United States Senate, and in the same period but one man-Joseph Johnson, of Harrison -had ever been selected from the counties west of the Alleghenies to fill the Gubernatorial chair." And thus he continues, "men in the West having political aspirations, saw in the supremacy of the East the impossibility of their realization, and smarting under what they deemed to be the greatest injustice, they began to dream of a time when conditions should exist under which a separation from the mother state would be made possible, and in the territory thus separated they, themselves, should assist in establishing a new common-wealth." The majority, however, still hoped that such a separation need not be resorted to in order to change conditions. They finally, in 1850 , succeeded in wresting from the Assembly another act "providing for the submission to the people the question of calling a convention to revise the Constitution." A favorable vote brought the new convention and, through it, a new constitution, with the redress of many evils, but it came too late to bring happiness to the West and peace to both, West and East.

It was the slave question which now became the real bone of contention. The predominance of the freeholders in the East, spelled, of course, opposition to the policies of the North of the Union and led to the victory of the movement favoring the secession of the whole State of Virginia from the Union, while the predominance of the non-freeholders in the counties west of the Alleghenies signified opposition to such an act, resulting in the separation of the western counties from the Old Dominion.

In both the eastern and western counties, spirited meetings were held in which the people gave expression to their respective, that is, opposing, views. In Preston county, a 
resolution was adopted at a mass meeting on November I2, I860, declaring that "any attempt upon the part of the State to secede will meet with the unqualified disapprobation of the people of the county." On November 24, the people of Harrison county proclaimed that they would "first exhaust all constitutional remedies for redress before they will resort to any violent measures"; that "the ballot box is the only medimm known to the Constitution for redress of grievances." Similar resolutions were adopted at Morgantown, Monongalia county, Taylor county, and by the citizens of Wheeling. Nevertheless, the secession ordinance passed in a convention which had been called by the Assembly in an extra session held in obedience to a request irom the Governor. Conventions had heretofore been called by referendum and, naturally, the opposition refused to acknowledge the constitutionality of the Governor's and the Assembly's procedure. The act of the Assembly had provided, however, that the decision of the Convention on the question of secession should be submitted to popular vote.

The ordinance of secession had passed in secret session on April I7, I86I ; with yeas: 88, nays: 55 . Of the delegates from western Virginia "twenty-nine had voted against it, nine for it, seven were absent and one excused."101 After many meetings of protest in the Western cities and counties, a gathering at Clarksburg of nearly twelve hundred citizens of Harrison county on April 22, called for a general convention to be held at Wheeling on the I $3^{\text {th }}$ of May. This, the first Wheeling Convention, met, "determined to save Western Virginia to the Federal Union." A report of the Committee on resolutions advised that, if the secession ordinance should be adopted by a popular majority, the dissenting counties elect delegates to a new Wheeling convention for June II, "the business of which should be to devise such measures as the safety and welfare of the people would demand."

101 McPherson, p. 7. 
The popular vote on the ordinance of separation was almost unanimous against it in Western Virginia, while with equal unanimity Eastern Virginia voted in favor of it. It was carried by a large majority of the votes cast." ${ }^{102}$

The second Wheeling Convention, called in pursuance of a resolution of the first Wheeling Convention of May I3, assembled in Washington Hall on June II. Two days later it issued "a declaration of the people of Virginia represented in Convention at the City of Wheling." The next day it began the reorganization of the state government. The new General Assembly, whose members were duly chosen at the occasion of the vote of the secession ordinance, convened on July I and sent new representatives to the Congress in Washington. On August 6 the Convention assembled once more and three days later declared "all ordinances, acts, orders ... of the Convention which assembled at Richmond on the I $3^{\text {th }}$ of February last, being without authority of the people of Virginia constitutionally given .... illegal, inoperative, null, void and without force and effect." It then passed an ordinance providing for the "formation of a new state out of a portion of the territory of this state," the new state to be called the State of Kanawha. This ordinance was to be and was submitted to a plebiscite in the disaffected sections on the fourth Tuesday of the ensuing October. The vote, when taken, "stood eighteen thousand four hundred and eight for the new State, and seven hundred and eighty-one against it." At the Constitutional Convention called by the new Governor for November the name of the new State was changed to West Virginia.

In connection with the principle of self-determination as applied in the secession movement, reference should here

102 Appleton's American Annual Cyclopædia, r86r, p. 738. McPherson gives the total votes cast' as 128,884 for and $32, \mathrm{I} 34$ against secession (McPherson, p. S). while Lewis claims for Western Virginia alone 40,000 against secession out of 44,000 votes cast in that part of the Old Dominion (Lewis, p. 356). 
be made to the doctrine of popular or squatter sovereignty. The essence of the loctrine is found in a letter of Lewis Cass, of December 24, 1847 , in which the writer "asserts that the principle of the Wilmot proviso 'should be kept out of the national legislature, and left to the people of the confederacy in their respective local governments'; and that, as to the territories themselves, the people inhabiting them should be left 'to regulate their internal concerns in their own way." "The advocates of this theory, among them Stephen A. Douglas, "generally accepted the territorial section of the Constitution ... as applicable, not only to the territory possessed by the United States in 1788 , but prospectively to any which might be acquired thereafter." Thus they held "that Congress might make any 'rules and regulations' it might deem proper for the territories, including the Mexican acquisition; but that, in making these rules and regulations, it was wiser and better for Congress to allow the 'inchoate state' to shape its own destiny at its own will. Properly ... there was nothing in the dogma which could constitutionally prohibit Congress from making rules for or against slavery in the territories, if it should so determine, though gradually Douglas and some of its more enthusiastic advocates grew into the belief that popular sovereignty was the constitutional right of the people of the territories, which Congress could not abridge." After the new Republican Farty had gained control of the House of Representatives in $1855^{-1857}$, the South came to the realization that "if a democratic Congress might make a 'regulation' empowering the people of the territories to control slavery therein, a Congress of opposite views might with equal justice make a 'regulation' of its own, abolishing slavery therein." As a result "the whole South came to repudiate popular sovereignty and the territorial section of the Constitution, and rested on the Calhoun doctrine that Congress and the immigrant both entered the territory with all the limitations of the Constitution upon them, including 
its provisions for the protection of slave property as well as property of other kinds." In I857 the United States Supreme Court, in the Dred Scott case, "decided against Douglas and popular sovereignty, and for the full vigor of the Calhoun theory." It was through its hold upon the South that the Calhoun doctrine furnished "the connecting link between the theory of state sovereignty and its practical enforcement by secession." ${ }^{103}$

The recent purchase of the Danish West Indies by the United States was preceded by several earlier attempts to consummate such a transaction. After Secretary of State Seward had broached the subject to the Danish minister at Washington in 1865 , Denmark offered, two years later, to sell to the United States the two islands of St. Thomas and St. John for the sum of $\$ 5,000,000$ each and indicated her willingness to cede St. Croix for a like price. An agreement was reached for the sale of the former two for $\$ 7,500,000$. Both Houses of the Danish Diet gave their approval. ${ }^{104}$ "Seward gave his unofficial consent to the holding of an election on the islands to ascertain the will of the inhabitants. ${ }^{105}$ The plebiscite on the islands "carried in favor of annexation by the nearly unanimous vote of I,244 to 22." The project, however, was frustrated by the opposition of the United States Senate, or rather, that of the Foreign Relations Committee under Senator Charles Sumner, the "implacable enemy of President Johnson."

${ }^{103}$ The foregoing quotations are from Alex. Johnston's article on Popular Sovereignty, in Lalor's Cyclopædia of Political Science, Political Economy and of the Political History of the United States.

${ }^{104}$ W. F. Johnson, The Story of the Danish Islands, in The North American Review, Sept., 1916, vol. cciv, pp. 379-384.

105 Seward had at first positively refused to consider any plebiscite but finally gave his unofficial consent in deference to Denmark's insistence on a popular sanction of the transfer (ibid., p. 384). The Danish insistence on the plebiscite was due to Denmark's interest in the employment of the plebiscite in international affairs in view of her hope of regaining the Northern part of Schleswig on the basis of Art. $V$ of the Treaty of Prague of 1866 , which had prescribed a plebiscite in that section. On this point see also Wambaugh, pp. I 49-I 50 .

106 Johnson, pp. 385-386. 
The plebiscite taken in Denmark on December I4, 19I6, on the question of sale, resulting in a vote of 283.694 for and 157,596 against the cession of the islands, ${ }^{107}$ does not concern us here since it does not include the voice and votes of the inhabitants of the territories to be transferred.

In 1879 the South American States, Peru and Bolivia, became involved in war with Chile. The conflict lasted several years. After a series of defeats on land and sea Peru and her ally were forced to sign a treaty of peace, ratified on March 8, I884. Articles two and three of this Treaty stipulated that:

II. Tarapaca to be ceded to Chile unconditionally forever.

III. The territories of Tacna and Arica, as far as the river Sama, are to be held by Chile for ten years, and it is then to be determined by popular vote, whether those territories are to belong to Chile or Peru. ${ }^{168}$

This plebiscite has however never been held because " at the close of the ten years Chile apparently distrusted the result of the plebiscite, and the matter was allowed to drag on."109

The significance of the plebiscites in American politics is to be found in the fact that though the effect of the Assembly votes and referenda in the seceding States was an-

${ }_{107} \mathrm{~W}$. Westergaard, The Danish West Indies, New York, 1917, p. 261 .

108 C. R. Markham, A History of Peru, Chicago, 1892, pp. 423-424. 109 The New International Encyclopedia, Peru. On August I3, 1900, Abraham Konig, Chilean Minister to Bolivia, made the following statement in a note to the Bolivian Foreign Office: "Chile has occupied the coast and taken possession of it by the same right which Germany exercised when she annexed Alsace and Lorraine. ... Onr rights are the result of victory, which is the supreme law of nations. That the coast is rich and worth many millions, we already know. We keep it because it is valuable. Were it worthless, we would have no interest in retaining it" (The Question of the Pacific. America's Alsace and Lorraine. The Conquest by Chile in I879. Illuminating Documents from the Department of State of the United States of America). For a detailed account of the negotiations between Peru and Chile since the signing of the Peace treaty of 1884 see Wambaugh, pp. 156-165. 
nulled by the outcome of the Civil War, the separation of West Virginia on the basis of popular vote has continued. ${ }^{110}$

An important consideration in the case of the acquisition of the Danish West Indies is the refusal of the American State Department to give official sanction to the plebiscite held in the territories transferred from Danish to United States sovereignty. ${ }^{111}$

110 See below, pp. 167-168.

111 The international legal aspect of this refusal is discussed in chapter viii, pp. I72-I73. 


\section{CHAPTER VI}

\section{The Plebiscite in tile Peace Treaties Ending the WORLD WAR}

Because of the growing disaffection of the foreign elements in some of the countries involved in the late World War, the Allied and Associated Powers found it expedient to offer a settlement of the aspirations of the freedom-seeking peoples on the basis of the principle of national selfdetermination. Thus the historical development of the plebiscite as the mode of expression of this principle of self-definition would seem to have assumed a new phase. Heretofore the principle of national self-determination had been recognized, and the plebiscite had been employed in international affairs only in individual cases and with the consent of or upon pressure from the power or powers directly or indirectly interested in each instance as it presented itself. With the embodiment of the principle of national self-determination in the officially defined war aims of the Allied and Associated Powers and the submission, even though enforced, of the Central Powers on the basis of these expressed aims, we have in the Peace Treaties the provision for plebiscites apparently sanctioned by all the large and a great number of the snaller nations of the world.

By the Brest-Litovsk Treaty concluded and signed on March 3, I9I8, between Russia and the Central Powers, the former consents in Article III that "the territories lying to the west of the line agreed upon by the contracting parties which formerly belonged to Russia will no longer be subject to Russian sovereignty, . . ." that "Russia refrains from all interference in the internal relations of these territories" and that "Germany and Austria-Hungary ... determine the future status of these territories in agree- 
ment with their population." In Article VI Russia recognizes the independence of Ukrania and "obligates herself to conclude peace at once with the Ukranian People's Republic and to recognize the treaty of peace between that State and the Powers of the Quadruple Alliance. . . ." Article 7 of the Supplementary Treaty signed at Berlin, August 27, 1918, reads in part:

Russia, taking account of the condition at present existing in Esthonia and Livonia, renounces sovereignty over these regions, as well as all interference in their internal affairs.

The same article provides that "their future fate shall be decided in agreement with their inhabitants."

Article Io of the same supplement stipulates as follows:

With regard to Esthonia, Livonia, Courland, and Lithuania, agreements, among others, are to be concluded with Russia, as to the following points:

I. With regard to the nationality of the former Russian inhabitants of these territories, as to which they must in any case be allowed the right of option and departure ...;

5. With regard to the regulation of the new frontiers;

6 . With regard to the effect of the territorial alterations on the State treaties.

By Article VI of the Treaty of March 3, Germany has secured the right to occupy Esthonia and Livonia by a German police force until security is insured by proper national institutions and public order has been established."

There is in the Brest-Litovsk treaties no provision for the application of a plebiscite in any of the territories separated from Russia. The nearest reference to a consent of the people is found in the statement that the future fate of Esthonia and Livonia "shall be decided in agreement with their inhabitants." From a Protest to the German Government by representatives of the Provisional Esthonian Government against the Treaty of Brest-Litovsk ${ }^{2}$ it appears that "by a vote of the General Esthonian Assembly [Landtag], which as the legal representative of United Esthonia,

1 The text used is that published for the United States Department of State. "Texts of the Russian 'Peace' (With Maps)," Washington, Govt. Printing Office, I9I8.

2 Ibid., pp. 223-226. 
proclaimed the political independence of Esthonia on November 28, 1917, a Provisional Esthonian Government was formed. Before the invasion of German troops on February 24, I9I8, this Provisional Government, supported by national Esthonian troops, and in fulfilment of the vote of November 28, proclaimed the republican form of government in Esthonia, and at once reestablished political order in most of the districts of the country." The Protest charges the German military police force with the usual method of forcing a favorable public expression for annexation: the press is censored, forced to print pro-German editorials supplied by the forces of occupation, or to be suppressed; all free expression is made impossible by the threat of heavy fines and death; the national troops are disarmed; administrative and local self-governing institutions in town and country, created by the Esthonian Assembly, are set aside. In their place committees have been appointed from the German minority population which, according to the latest Esthonian statistics, is less than two and one-half per cent. The German language is made compulsory for private correspondence and given first place in schools. In place of the Esthonian elected Assembly, a new Assembly has been called by summons of "a few delegates of the communal elders of the peasant communes, as if there was not also an overwhelming Esthonian majority in all the towns of Esthonia." The Protest continues:

Subsequently, in order to give the lacking authoritativeness to the acts of the United Diet, called together in this way, in regard to the annexation of Esthonia to the German Empire, representatives of the German nobility, of the German pastors, and of other Baltic German groups, with the active support of the military power, started a secret collecting of signatures among the Esthonian population in favor of a closer political connection between Esthonia and the German Empire; in doing this every means was used to terrorize the people in order to secure the desired result.

The cessions of territory demanded by the Central Powers in the Treaty of Bucharest of May 7, 1918, between Roumania and the Quadruple Alliance, provide for no 
plebiscites, but they grant option with the right, not demand, of emigration. ${ }^{3}$

By the force of the Peace Treaty between the Allied and Associated Powers and Germany, the Treaties of BrestLitovsk and Bucharest have both been annulled. It is chiefly the Treaty of Versailles which requires consideration of territorial changes on the basis of the plebiscite."

According to Articles 32,33 and 34 of the Treaty of Versailles, Germany "recognizes the full sovereignty of Belgium over the whole of the contested territory of Moresnet [called Moresnet neutre]," and she renounces in favor of Belgium German sovereignty over Prussian Moresnet and the whole of the Kreise of Eupen and of Malmédy. "During six months after the coming into force of this Treaty, registers will be opened by the Belgian authority at Eupen and Malmédy in which the inhabitants of the above territory will be entitled to record in writing a desire to see the whole or part of it remain under German sovereignty."

No expression of opinion is provided for in Neutral and Prussian Moresnet.

The result of the public expressions of opinion in Eupen and Malmédy "will be communicated by the Belgian Government to the League of Nations, and Belgium undertakes to accept the decision of the League."

The expression of opinion here provided for is not a free public vote in the sense of a plebiscite for the reason that what is requested is the expression of opinion in writing in public registers. Though the Treaty does not specify the mode of registry, it is clear that in order to give to these expressions in writing any value and significance the individual thus expressing his opinion must either attach his signature or divulge his name to the supervisor of the

${ }^{3}$ Text used is that published for the United States Department of State. "Text of the Roumanian 'Peace' (With Maps)," Washington, Govt. Printing Office, I918.

4 Text used is that' of the "Treaty of Peace with Germany" published as number 142 by the American Association for International Conciliation, New York, Sept., I9I9. 
recorls. This, of course, would deprive the "expression of opinion" of the secrecy essential to a free and unrestrained voicing of a popular will.

Article 37 provides that "within the two years following the definite transfer of the sovereignty over the territories assigned to Belgium ... German nationals over i 8 years of age habitually resident in those territories will be entitled to opt for German nationality." It stipulates further that "persons who have exercised the above right to opt must within the ensuing twelve months transfer their place of residence to Germany."

Concerning the cessions of German territory to Belgium, the German Peace Delegation submitted to the Allied and Associated Powers the following comment ${ }^{5}$ in regard to Neutral and Prussian Moresnet, where no expression of opinion is provided for: "Neutral Moresnet owes its origin to the Prussian-Dutch frontier treaty of June 26, I8I6. It is a district with 3,500 inhabitants, the majority of which are German by origin and language. . . Prussian Moresnet, too, which belongs to the district of Eupen, has a predominantly German population. Nevertheless, not even a plebiscite has been provided in these territories."

As to the other territories to be ceded it is stated that "historically the districts of Eupen and Malmédy have never belonged to Belgium, or to any of the political formations which may be considered as predecessors of the present Belgium." In the district of Eupen which is claimed as purely German, "out of 25,000 inhabitants during the last census only ninety-eight named Walloonian as their mother tongue."

In Malmédy the Walloonians "are considerably in the minority" as the district "has among its 37,000 inhabitants a population of about 9,500 souls speaking Walloonian as their mother tongue."

The comment then raises two objections to the cessions

5 "Comments by the German Delegation on the Conditions of Peace," published as number 143 by the American Association for International Conciliation, New York, Oct., I9rg. 
stipulated. In the first place, "the German Government cannot, on principle, consent to the cession of indisputably German territories; and a vote cannot be applied to such territories": the second objection is that "apart from this the demand of a cession of the districts of Eupen and Malmédy to Belgium contravenes the principle according to which the settlement of all questions regarding sovereignty is to be brought about, on the basis of free acceptance on the part of the population inmediately concerned."

The course of reasoning here applied seems to be this: in territories of indisputably German populations no plebiscites can be consented to and their cession by Germany cannot be conceded. But if their cession is enforced, Germany must insist on the application of the principle of national self-determination by way of a free and secret vote.

The German comment assures the Allies that, in order to secure for Belgium the benefits of the German forests in these districts in reparation for the Belgian forests destroyed, "the German Government declares itself ready, by contracting for the supply of wood, to comply with these aspirations." It adds that "the German Government must point out the inadmissibility of bartering human beings from one sovereignty to another, merely for the sake of wood and zink ore."

The Allied reply to these observations bases the transfer of Eupen and Malmédy on the grounds that these territories were "separated from the neighboring Belgian lands of Limburg, Liège, and Luxemburg in I8I4-I8I5, that at the time "no account was taken of the desires of the peoples, nor of geographical or linguistic frontiers," that "this region has continued in close economic and social relations with the adjacent portions of Belgium," that "in spite of a century of Prussification the Walloon speech has maintained itself among several thousand of its inhabitants," and that "at the same time the territory has been made a basis for German militarism by the construction of the great camp at Elsenborn and various strategic railways di- 
rected against Belgium." To the Allied Powers these "reasons seem sufficient to justify the union of the territory to Belgium, provided the petitions to this effect are sufficiently supported by the population of the district.",

The petitions here referred to must be those of the Walloon population asking for incorporation.

The German criticism of the insufficient provision for a free and unconstrained vote, is answered by the Allies' reply in the affirmation that "the Treaty makes provision for consulting the population under the auspices of the League of Nations."

The stiplations concerning the cession of Neutral Moresnet remain as provided. Prussian Moresnet goes to Belgium, so the reply states, "in partial compensation for the destruction of Belgian forests."

Article 45 of the Treaty stipulates that:

As compensation for the destruction of the coal-mines in the north of France and as part payment towards the total reparation due from Germany for the damage resulting from the war, Germany cedes to France in full and absolute possession, with exclusive rights of exploitation, unencumbered and free from all debts and charges of any kind, the coal-mines situated in the Saar Basin as defined in Article 48.

This transfer of the mines does not ipso facto imply the change of sovereignty over the inhabitants. But Article 47 provides that:

In order to make in due time permanent provision for the government of the Saar Basin in accordance with the wishes of the populations, France and Germany agree to the provision of Chapter III of the Annex hereto.

Chapter II of the Annex here referred to provides for the transfer for fifteen years of the government of the Saar Basin "to a Commission representing the League of Nations." Chapter III contains the conditions under which the plebiscite is to be held at the end of this period. Upon

8 "Reply of the Allied and Associated Powers to the Observations of the German Delegation on the Conditions of Peace," published as number I44 by the American Association for International Conciliation, New York, November, I9I9. 
the result of this plebiscite depends the ultimate sovereignty of the Basin. The only measure suggesting an accord of the government with the wishes of the population during the fifteen years seems to be the inclusion in the membership of the Governing Commission to be chosen by the Council of the League of Nations of "one native inhabitant of the Saar Basin."

The temporary loss of German sovereignty "will not affect the existing nationality of the inhabitants of the territory of the Saar Basin." However, "no hindrance shall be placed in the way of those who wish to acquire a diferent nationality, but in such cases the acquisition of the new nationality will involve the loss of any other."

Paragraph II of the Annex provides for "the introduction or employment in the mines and their accessories and subsidiaries of workmen from without the Basin," and paragraph I4 gives the French State "the right of establishing and maintaining, as incidental to the mines, primary or technical schools for its employees and their children, and of causing instruction therein to be given in the French language, in accordance with such curriculum and by such teachers as it may select."

In a plebiscite to be held "at the termination of a period of fifteen years ... the population of the territory of the Saar Basin will be called upon to indicate their desires in the following manner:

A vote will take place by communes or districts, on the three following, alternatives: (a) maintenance of the régime established by the present Treaty and by this Annex; (b) union with France; (c) union with Germany.

All persons without distinction of sex, more than twenty years old at the date of the voting, residing in the territory at the date of the signature of the present Treaty, will have the right to vote.

The other conditions, methods, and the date of the voting shall be fixed by the Council of the League of Nations in such a way as to fix the freedom, secrecy and trustworthiness of the voting.

The League of Nations shall, after the voting, "decide on the sovereignty under which the territory is to be placed, taking into account the wishes of the inhabitants as expressed by the voting." 
The territory may be allotted to its final sovereign either in part or in sections, since the voting is to take place by conmunes.

The German comment concerning these provisions makes in effect the following points: the entire Saar Basin arrangement purports to be enforced "in compensation for the destruction of the coal mines in northern France." However, the territorial delimitations provided for go far beyond the land containing coal, "including, in addition, extensive forests, numerous lime works, glass factories, and other very profitable and partially world-renowned industries." The German Government is prepared to grant the coal demanded by France "by contracts of supply and by shares." Continuing the comment says:

According to the opinion on the economic situation expressed by the Allied and Associated Governments in their note of May 22, it would likewise be a fundamental error to believe in the necessity of exercising political sovereignty in a country in order to secure thereby an adequate portion of its production. ...

The draft of the peace treaty formulates a demand which tears from the German Empire a purely German territory, gives France economic control over it, and attempts also to annex it politically to France. ...

Among the 650,000 inhabitants there were in 1918 not even 100 French.

The one native member on the Governing Commission is not elected by the population, but appointed by the Council of the League of Nations, subject to recall. There is no representation of the people "with any legislative competence."

The use of the German language, the schools and religious practice are placed under control, and the French State is authorized to establish public and technical schools with French as their official language, taught by teachers of its own choice. The future position of every official and employee is rendered quite uncertain. ... The chief right of the citizen of the Saar district is that of cmigration, but there is no law to protect him from expulsion....

From the days of their appearance the authorities of the French Occupation Forces have taken recourse to every possible means in order to prepare the people for annexation to France. Every attempt is made to induce a population who have been exhausted by the hunger blockade and the exertions of the war, to apply already for French citizenship. Many who not only cling in their hearts to the old Fatherland, but make public profession of their attachment, are cxpelled from the country. 
The Allied reply reminds the German Delegation once more of the reparatory character of the Saar settlement. It justifies the extension of the frontiers beyond the coal lands by the desire "to secure the least possible interference with the present administrative units or with the daily vocations of this complex population." The Governing Commission is responsible to the League of Nations, not France. The territories will have their whole revenue applied to their own administrative unit and for the first time they will have "a government resident on the spot which will have no occupation and no interest except their welfare."

"The German note," the answer concludes, "constantly overlooks the fact that the whole arrangement is temporary, and that at the end of fifteen years the inhabitants will have a full and free right to choose the sovereignty under which they are to live."

In point of fact the German Government does not overlook the temporary character of the present arrangement, but its comment shows clearly the fear that the final outcome will be influenced and determined by the temporary arrangement. France has the right to employ French labor and thus is at least potentially in the position to swamp the territory. This would force the German population either to emigrate or to apply for French nationality, if in their opinion, this would seem to promise them opportunity for work. Since the Treaty provision for the plebiscite to be held at the end of the fifteen years of foreign rule gives the vote to all "persons without distinction of sex, more than twenty years old at the date of the voting, resident in the territory at the date of the signature of the present Treaty," those inhabitants of the Saar Basin, who, for economic reasons and against their wishes and desires might have assumed French nationality, would be entitled to vote. However, the assumption of French nationality under conditions assumed would in no way bind the voter to declare for union with France. In other words, in spite 
of the existing temporary arrangement the final decision, as far as the vote of the population is concerned, scems to depend entirely on the existing sentiment for or against Germany and on the consistency with which loyalty to Germany will be able to maintain itself. As far as the effect of emigration, voluntary or by force of expulsion, on the result of the plebiscite is concerned, it is clear that it could reduce the total number of those entitled to rote and thus the number of those actually voting, but it also is apparent that it does not effect in any way the number of those who might want to vote for Germany in proportion to the total number of those remaining and entitled to vote at all.

Article Iog of the Treaty provides that "the frontier between Germany and Denmark shall be fixed in conformity with the wishes of the population."

The Treaty of Prague of 1866 had given SchleswigHolstein to Prussia on condition that the population of the northern district of Schleswig should have the right to express its approval or disapproval of such a transfer by way of a plebiscite. This condition was, however, later eliminated from the treaty text by agreement between Austria and Prussia. ${ }^{7}$ The present Treaty provides for two zones, each to vote on different dates and the result of the vote in each to be determined on a different principle. In both zones, "every person will vote in the commune (Gemeinde) where he is domiciled or of which he [or she] is a native."

In the northern zone "the result will be determined by the majority of votes cast in the whole of this section."

The result in the second zone "will be determined by communes (Gemeinden), in accordance with the majority of the votes cast in each commune (Gemeinde)."

The right of option for Germany in the section allotted to Denmark and for Denmark in the part remaining with Germany is granted with the proviso that "persons who have exercised the above right to opt must within the ensu-

7 See abrove, p. I Io, note 6 I. 
ing twelve months transfer their place of residence to the State in favor of which they have opted."

The German reply declares the readiness of the German Government "to meet the Danish wishes for a new frontier corresponding to the principle of nationality, using the peace negotiations as a roundabout means of establishing it," but insists, "it cannot refrain from referring to the fact that the Schleswig question is not expressly mentioned in President Wilson's points." Therefore, "if Germany agrees to a plebiscite in Schleswig, she does this because she recognizes the right of self-determination of the peoples."

However, the German comment adds that Germany is "nevertheless not in a position to accept the formation of the voting districts, as well as the method and the time of voting, as proposed in the draft of the peace treaty."

Germany proposes one voting district whose boundary "toward the south shall coincide with the dividing line between the linguistic majorities, so that those communes shall vote which contain more than fifty per cent of Danes in an unbroken territorial unity."

The voting in this whole district, it is suggested, "shall be by communes."

In answer to the German proposals for the changes in the method of the voting and delimitation of the voting districts the Allied reply concedes that "in consequence of a request made by the Danish Government it has been decided to alter the limits of the territory within which the plebiscite will be held in accordance with their wishes." No further changes are affected.

The territories to be ceded by Germany to the States of Poland and Czecho-Slovakia present a problem so complicated in its racial aspect that noi boundary arrangement seems possible which will not include in German territory Poles and Czecho-Slovaks, or Germans in the areas transferred to the new States.

The Treaty provides the transfer of German territory to Poland in part as outright cession, without consultation of 
the population, in part as cession conditioned upon the consent or refusal of the inlabitants to be transferred to Polish allegiance. There is naturally a wide divergence of opinion between the Allies and Associated Powers and Germany as to the proper lines of demarcation of the first and second zones. That the Powers who framed the terms of the Treaty were fully conscious of the fact that the sections of German territory transferred to Poland without a plebiscite contain a considerable number of Germans is shown by the inclusion in the Allied-Polish Treaty of guarantees of the rights of racial minorities.

The territories transferred without vote constitute parts of the Provinces of Posen, West Prussia, ${ }^{8}$ Pommern and, according to the original draft of the Treaty, of Schlesien.

The German reply takes exception to this transfer without regard to the racial configuration. Abiding by the consequences of its acceptance of President Wilson's Fourteen Points, Germany declares herself ready to yield to Poland those sections of Posen and West Prussia which are "inhabited by indisputably Polish populations."

Under the provisions of the first draft of the Treaty, Upper Silesia was to be ceded without a vote. The German reply contests this decision and in its argument states:

The districts of Upper Silesia denanded for Poland are not inhabited by an indisputably Polish population. The will of the population has been clearly expressed in the elections to the Reichstag in 1903 and 1907 . Before 1903 not one Polish deputy had been elected. In 1907, at the general, direct and absolutely secret election for the Reichstag the Poles received II 5,000 votes, the Germans I76,287; in 1912 the Poles obtained 93,029 and the Germans 210,100 votes; at the time of the elections for the National Assemblies (Nationalversammlungen) of the Empire in 1919, when all citizens of cither sex above the age of twenty had cast their votes in a general, equal, direct and strictly secret election, the Poles proclaimed their abstention from voting. In spite of this, almost sixty per cent

8 Only in a small section of the province of West Prussia, "comprising the Kreise of Stuhm and Rosenberg and the portion of the Kreis of Marienburg which is situated east of the Nogat and that of Marienwerder east of the Vistula, the inhabitants will be called upon to indicate by a vote, to be taken in each commune (Gemeinde), whether they desire the various communes situated in this territory to belong to Poland or to East Prussia." 
of all persons entitled to vote voted and they voted for the German candidates nominated. As experience shows that at German elections about ten per cent of the electors are hindered from voting for external reasons, the Poles can claim for themselves at the highest only one-third of the vote.

As an additional argument against the cession of Upper Silesia, is cited the imperative need of Germany for the Silesian coal. To this the Allied and Associated Powers respond:

It is recognized that the problem here differs from that in Posen and West Prussia for the reason that Upper Silesia was not a part of the Polish territories when dismembered by the Partition. It may be said that Poland has no legal claim to the cession of Upper Silesia; it is emphatically not true that she has no claim which could be supported on the principles of President Wilson. In the district to be ceded, the majority of the population is indisputably Polish. Every German book of reference, every school book teaches the German child that the inhabitants are Polish in origin and in speech. The Allied and Associated Powers would have been acting in complete violation of the principles which the German Government itself professes to accept had they left' unregarded the Polish claims to this district.

However, the revised draft of the treaty provides for a plebiscite in Upper Silesia and guarantees Germany a proper share in the output of the Silesian coal mines if the vote should be favorable to the inclusion of the territory in Poland.

Concerning the cession of Posen the German reply objects on the grounds that: "the province of Posen as a whole cannot be regarded as a district inhabited by an indisputably Polish population. Large parts of this province have been inhabited for many centuries by a predominantly German population; outside these districts there are enclaves of the same character." It charges that the proposed boundary lines "are not based on the principle of nationality . . . but on that of the strategic preparation of an attack against German territories." In conclusion it is added that "these [strategic] considerations, however, cannot possess any importance if the relations between Germany and Poland in the future are to be subject to the regulations of the League of Nations." 
According to the German statement the sections of West Prussia to be ceded, without vote, hold about 744,000 Germans against 580,000 Poles and Cassubians.

The Treaty provides for a plebiscite in the southern section of the Province of East Prussia to decide whether this region shall go to Poland or remain with Germany. Germany protests against this proposed cession and questions the necessity of an appeal to the population. "These districts... are not inhabited by an indisputably Polish population. The circumstance that, in isolated regions, a non-German language has survived, is in itself of no moment, for, even in the oldest homogeneous States, this condition may be observed; the Bretons, Welsh, and the Basques may be mentioned in this connection. ..."

The Allied reply justifies the cession of West Prussia and of Posen without a plebiscite on historical grounds. The Allied promise of the restoration of Poland demands the retrocession by Germany of West Prussia. The principle of nationality has been the guiding line as far as the former grounds would permit. However, slight rectifications of the frontiers on stricter racial lines were embodied in the final draft of the Treaty.

The German objections concerning the Province of Posen were overruled on the ground that the existence of German claves, etc., ws due largely to Prussianization and that it would be impossible to draw a frontier which would not meet with some objection.

The plebiscite in the southern part of East Prussia is insisted upon.

The right of option is granted in the case of all these cessions.

By the Treaty of Peace, Germany is forced to renounce in favor of the Principal Allied and Associated Powers all rights and title over the City of Danzig and the adjoining territory which is to be constituted the Free City of Danzig under the protection of the League of Nations. 
A constitution for the Free City of Danzig is to be drawn up by the duly appointed representatives of the Free City in agreement with the High Commission to be appointed by the League of Nations.

The Free City of Danzig is to be included in the Polish Customs frontiers and Poland is to conduct the foreign relations of the Free City.

German nationality is lost ipso facto by the coming into force of the Treaty. The inhabitants become nationals of the Free City of Danzig.

Aside from the plea that Danzig is a purely German city, the following quotation gives the chief points of the German protest against the cession:

In accepting Point I 3 of President Wilson's address of January 8, I9I8, Germany has agreed that the Polish State to be erected "should be assured a free and secure access to the sea." The German Government has done so in recognition of the address which President Wilson delivered to the Senate on January 22, I9I7, when he said:

So far as practicable, moreover, every great people now struggling toward a full development of its resources and of its powers should be assured a direct outlet to the great highways of the sea. Where this cannot be done by the cession of territory, it can no doubt be done by the neutralization of direct rights of way under the general guarantee which will assure peace itself. With a right comity of arrangcment no nation need be shut away from free access to the open paths of the world's commerce.

Germany offered the following solution:

In accordance with the above principles and in order to fulfill the obligation accepted by the German government, viz., to give Poland a free and secure access to the sea, the German Government' is ready to make the ports of Memel, Königsberg, and Danzig free ports and to grant in these ports far-reaching rights to Poland.

The Allied reply grants that "the population of Danzig is, and has for long been, predominantly German" and it adds that "just for this reason, it is not proposed to incorporate it in Poland." But Danzig is to be ceded by Germany for the good of Danzig itself and for the benefit of Poland. 
The Allied reply reminds Germany that the present settlement, "will preserve the character which Danzig held during many centuries, and, indeed, until forcibly, and contrary to the will of the inhabitants, it was annexed to the Prussian State. . . But Danzig, when a Hansa city, like many other Hansa cities, lay outside the political frontiers of Germany, and in union with Poland enjoyed a large measure of local independence and great commercial prosperity. It will now be replaced in a position similar to that which it held for so many centuries." As for the second reason the reply states that "the economic interests of Danzig and Poland are identical. For Danzig, as the great port of the valley of the Vistula, the most intimate connection with Poland is essential. The amnexation of West Prussia, including Danzig, to Germany deprived Poland of that direct access to the sea which was hers by right. The Allied and Associated Powers propose that this direct access shall be restored."

Danzig then is detached from Germany on the principle of historic and economic considerations, without the consultation of an admittedly predominant German population.

The port and city and district of Memel are to be ceded by Germany to the Principal Allied and Associated Powers, and "Germany undertakes to accept the settlement made by the ... Powers in regard to these territories, particularly insofar as concerns the nationality of the inhabitants."

The German reply states that of the total population of the district to be ceded about 68,000 are German against 54,000 Lithuanians. "Memel particularly is a purely German town." Only in the district (Kreis) Heydekrug does a slight majority of a Lithuanian speaking population exist. In the Kreis Memel only forty-four per cent, in Tilsit twenty-three per cent, and in Ragnit but twelve per cent speak Lithuanian. All speak German besides. As a further reason against cession is adduced the religious differences of the Catholic Lithuanians of the former Russian Empire and the Protestant Lithuanians of Prussia. 
The Allied answer claims the territory as predominantly Lithuanian in origin and in speech. Hence the cession does not conflict "with the principle of nationality" and "the fact that the city of Memel itself is in large part German is no justification for maintaining the district under German sovereignty, particularly in view of the fact that the port of Memel is the only sea outlet for Lithuania."

In this answer we have in the first part a rejection of the German charge that the transfer conflicts with the principle of nationality, in the second part the assertion that the principle of nationality cannot be invoked by the largely German city of Memel, because it is the only sea outlet for Lithuania.

Other transfers of German territory without a plebiscite are stipulated in Article 83. Germany renounces in favor of the Czecho-Slovak State all rights and title over a portion of Silesian territory, and in case the final demarcation of the Polish-German frontier leaves part of the Kreis Leobschütz isolated from Germany, this district is to fall, without vote, to Czecho-Slovakia.

Here, as in the case of German cessions to Poland, the Treaty recognizes the fact that the territories transferred contain a considerable German population by the guarantee given in Article 86 that "the Czecho-Slovak State accepts and agrees to embody in a Treaty with the Principal Allied and Associated Powers such provisions as may be deemed necessary by the said Powers to protect the interests of inhabitants of that State who differ from the majority of the population in race, language or religion."

The right of option is provided.

The Peace Treaty of Versailles requires of Germany the renunciation of her sovereignty over all her colonial possessions in favor of the Principal Allied and Associated Powers.

The German reply considers this regulation as "in irreconcilable contradiction to Point 5 of the Address to Con- 
gress of January 8, I9IS, in which President Wilson promises a free, sincere and absolutely impartial settlement of all colonial claims."

In justification of their demand for Germany's relinquishment of her colonies, the Allies counter with the reference to President Wilson's same address to Congress, called upon by the Germans to prove the injustice of the Allies' request. Their response reads in part as follows:

In requiring Germany to renounce all her rights and claims to her overseas possessions, the Allied and Associated Powers placed before every other consideration the interests of the native populations advocated by President Wilson in the fifth point of his fourteen points mentioned in his address of the 8th of January, I9I8. Reference to the evidence from German sources previous to the war, of an official as well as of a private character, and to the formal charges made in the Reichstag, especially by MM. Erzberger and Noske, will suffice to throw full light upon the German colonial administration. . . .

As an additional reason for their demand of the German colonies they answer that:

Moreover, the Allied and Associated Powers felt themselves compelled to safeguard their own security and the peace of the world against a military imperialism which sought to establish bases whence it could pursue a policy of interference and intimidation against the other Powers.

The cession by Germany to France of Alsace-Lorraine is to be unconditional, without consultation of the population as to its consent or opposition of such a transfer, in order "to redress the wrong done by Germany in IS7 I both to the rights of France and to the wishes of the population of Alsace and Lorraine, which were separated from that country in spite of the solemn protest of their representatives at the Assembly of Bordeaux."

The right of option by the inhabitants is not specified in the Treaty. French nationality is granted by the cession ifso facto to "(I) persons who lost French nationality by the application of the Franco-German Treaty of May Io, I87I, and who have not since that date acquired any nationality other than German; (2) the legitimate or natural descendants of the persons referred to in the immediately preceding paragraph. ..." 
French nationality may be claimed within the period of one year by Germans doniciled in Alsace-Lorraine "since a date previous to July 15,1870 , or if one of their ascendants was at that time domiciled in Alsace Lorraine," and by "all Germans born or domiciled in Alsace-Lorraine who have served in the Allied or Associated armies during the present war, and their descendants."

Subject to the above provisions, "Germans born or domiciled in Alsace-Lorraine shall not acquire French nationality by reason of the restoration of Alsace-Lorraine to France, even though they may have the status of citizens of AlsaceLorraine. They may acquire French nationality only by naturalization. ..."

Article 53 of the Treaty provides for separate agreements between France and Germany "dealing with the interests of the inhabitants, ... it being understood that Germany undertakes, . . . to recognise and accept the regulations laid down in the Annex hereto regarding the nationality of the inhabitants or natives of the said territories, not to claim at any time or in any place whatsoever as German nationals those who shall have been declared on any ground to be French, to receive all others in her territory. . . ."

The above quotation seems to indicate, or at least to permit of the assumption of the right claimed by France to force all or any Germans of Alsace-Lorraine who have not been declared French nationals to return to Germany, an inference which is apparently strengthened by the concluding remark of Article 53, which states that "those German nationals who, without acquiring French nationality shall receive permission from the French Government to reside in the said territories, shall not be subjected to the provisions of the said Article."

The comment of the German Peace Delegation admits that "according to the present general conceptions of right, an injustice was committed in $187 \mathrm{I}$ by the failure to hold a plebiscite." However, Germany "believed she was justified in doing so by the previous procedure of France and 
by the racial kinship of the population." In this connection the German reply states:

For the most part, Alsace-Lorraine is old German territory, having become more than a thousand years ago a part of the old German Empire. In the seventeenth and eighteenth centuries the German parts passed, mainly by conquest, under French sovereignty, without any reference to the wishes of the people, and frequently in the face of their opposition. The French regime has indeed succeeded in bringing about a political annexation to France, but the racial and political characteristics of the inhabitants have been so little influenced that even to-day four-fifths of the country's population is still German in its language and customs.

Germany has declared her willingness to right the wrong of 1871 , but the proposed outright cession of Alsace-Lorraine, without the consultation of the inhabitants, would be "a new and greater injustice." Such a settlement would not tend "to make a peace in the interest of all" and "the danger would rather arise that, in the future, this question would be the cause of new hatred among the nations."

Germany proposes a vote for the entire population of Alsace-Lorraine, to "provide for the three following possibilities: (a) Union with France, (b) Union with the German Empire as a Free State, or (c) Complete independence, especially liberty of economic relations with any of its neighbors."

In 187 I France protested the cession of Alsace-Lorraine to Germany not on the grounds of the objection of the inhabitants, but on the principle of the inviolability of French soil. However, in their reply to the present German argument the Allied rejoinder stresses the point of popular protest against the cession of $\mathrm{I} 87 \mathrm{I}$. Hence, since "to right a wrong is to replace things, so far as possible, in the state in which they were before being disturbed by the wrong," Alsace-Lorraine must be returned on the basis of the sentiment of the people as it existed in $187 \mathrm{I}$.

The German insistence on the consultation of the inhabitants as to their sentiments at the present time is rejected on the ground that "the population of Alsace and Lorraine has never asked for it," that Alsace and Lorraine have 
thrown themselves into the arms of France "as into those of a long-lost mother" and that "a treaty founded on the right of self-determination of peoples cannot but take note of a people's will so solemnly proclaimed."

The German arguments, "based on history and language ... are formally contested by the Allied and Associated Powers and do not modify their point of view."

The request for a settlement of the question of nationality applying equally and to all the inhabitants and for the right of option for those wishing to make use of it in favor of Germany is rejected.

By the terms of the Treaty Germany is bound to acknowledge and to respect "strictly the independence of Austria, within the frontiers which may be fixed in a Treaty between tha State and the Principal Allied and Associated Powers." Germany agrees "that this independence shall be inalienable, except with the consent of the Council of the League of Nations."

Germany responds that she "has never had, and never will have, any intention of shifting the Austro-German frontier by force. But it is admitted that "should the population of Austria, whose history and culture have been most intimately connected with its mother country Germany, for more than a thousand years, desire to restore the national connection with Germany, which was but recently severed by war, Germany cannot pledge herself to oppose that desire of her German brothers in Austria, as the right of self-determination should apply universally and not only to the disadvantage of Germany."

To this the Allies reply no more and no less than the following: "The Allied and Associated Powers take note of the declaration in which Germany declares that she "has never had and never will have the intention of changing by violence the frontier between Germany and Austria."

Article 88 of the Treaty signed on September 10, 1919, between the Principal Allied and Associated Powers and 
Austria declares that "the independence of Austria is inalienable otherwise than with the consent of the Council of the League of Nations."

By Articles 49-50 of the same Treaty Austria is compelled to renounce part of her former territory to Italy, JugoSlavia, Czecho-Slovakia, and Rommania. The plebiscite seems to be prescribed only in one instance: "The inhabitants of the Klagenfurt area will be called upon . . . to indicate by a vote the State to which they wish the territory to belong." 10

Concerning the cessions required of Hungary, Bulgaria, and Turkey, no definite statement can be made, since the texts of the treaties in question are not yet accessible.

9 Text of the Treaty used is that published in the Congressional Record, Sept. I5, 1919.

10 The plebiscite in the southern part of the Klagenfurt area has taken place in October, 1920 . Of a total of 36,948 votes cast, 21,852 were counted for Austria (Press dispatch of Oct. I4). Since this vote was favorable to Austria, the plebiscite in the northern zone, conditionally provided for in Treaty, need not be held. Of the plebiscites called for in the Treaty of Versailles, all have taken place except the one in Upper Silesia. In West Prussia 96,899 votes were cast in favor of Germany against 7,977 for Poland; in East Prussia 353,655 votes were reported for Germany and 7,405 for Poland, with 63 small districts maccounted (Press dispatch of July 13). The results of the plebiscites in the two Schleswig zones are given below, p. 200. Eupen and Malmédy have been definitely assigned to Belgium. 


\section{CHAPTER VII}

\section{The Practical and Theoretical Aspects of the Plebiscite}

In countries with democratic governments the popular will is ordinarily deemed equivalent to the will of a majority. Hence the plebiscite or referendum, when resorted to in matters of internal affairs, is employed as the means of establishing which side of the argument is represented by the majority and as such entitled to prevail.

When applied to the transfer of territory the plebiscite is supposed to serve a different purpose, namely, to secure recognition for a minority, that is, a minority in the whole state, but a majority in a particular territorial portion of it.

To illustrate: A state consists of two elements, a majority and a minority. The latter is dissatisfied with the form of government, the social, or religious, or any other, policy of the state, as enforced by the majority. If the minority can sufficiently increase its adherents it can change matters to suit itself. Majority and minority need, of course, not always be expressed in numbers alone; economic and other factors may furnish additional, and sometimes decisive, force to one or the other side. If the minority can not gain the required strength to alter conditions there is nothing left to do but to submit or to secede if this is possible. We have a concrete case of this kind in the separation of the Swedish-Norwegian union. Norway had tried in vain to induce Sweden to grant her separate representation in the consular service and in the cabinet and finally abrogated the union, forming an independent kingdom. Sweden accepted the new state of affairs after a plebiscite had established the fact that the separation corresponded to the nearly unanimous will of the Norwegian people. Equally clear-cut are 
the cases of the fusion of Valachia and Moldavia, the merof the Italian States, the secession of West Virginia, and the return of the Virginia section of the District of Columbia. But conditions are quite as often extremely complex, and when this is the case, the plebiscite must of necessity fall considerably short of its allotted function or even fail altogether. For what would have happened if the Norwegian vote had shown a considerable minority against the disruption of the union, or if it had turned out to be a tie vote? Judging from the statement made by $N$. Edén expressing the sentiment of the Swedish Riksdag that "in itself this Norwegian unanimity is a relief to us" and that "if the Union is to be dissolved, nothing would have made a settlement more difficult than a strong Norwegian minority against such a solution" ${ }_{1}$ we may well infer that resort to arms might have been the result. In Great Britain, Ireland is the minority against the majority represented by the rest of Britain. If a plebiscite held in Ireland should, or rather could, establish a universal wish for separation, then it would here again be serving the purpose of gaining recognition for the minority. Unfortunately Ireland itself has its own majority and minority and as matters now stand, no plebiscite could solve the question to the satisfaction of the two conflicting factions. Another instance of this type we have in the case of Alsace-Lorraine. In $187 \mathrm{I}$ the two provinces represented a solid minority against the newly created German Empire to which they were annexed against the evident will of the people. To-day a plebiscite taken on the question of retention by Germany or return to France would undoubtedly reveal in Alsace-Lorraine a majority and a minority, one way or other. Still, both Germany and France refuse to be swayed from their respective positions. Germany, up to the signing of the Peace Treaty, had consistently refused to consider the existence of whatever remained of the original sentiment in favor of France; France, on the other hand, in the Peace

1 See above, p. II4. 
Treaty, refused to recognize the possile existence of any sentiment in favor of Germany. The plebiscite suggested by the German reply to the first draft of the Treaty would undoubtedly establish a majority in favor of either France, Germany, or independence. But it also would establish a dissenting minority favoring one or the other of the alternatives to the decision of the majority.

In an editorial on "Self-Determination," a New York weekly ${ }^{2}$ discusses the analogous difficulties confronting the application of the principle of self-determination in the three Lithuanian provinces, Kovno, Vilna, and Suwalki. According to the Nation, the Lithuanian race constitutes 75 per cent of the first, I 8 per cent of the second, and 52 per cent of the third of these provinces. "How is the plebiscite to be taken?" the Nation asks. "For the three provinces as a unit," it answers, "the Lithuanians, though in a minority, might conceivably rally a majority for independence under the pull of historic traditions. If the provinces vote separately, then Vilna, the heart of Lithuania, might decide to stay with Russia, while Kovno would be certainly independent and Suwalki probably so." Suwalki again, offers another complication. Under Russian rule it formed a part of Poland. Will then, to quote the Nation, "the new independent Poland permit Suwalki to detach itself, or will it insist on keeping the province in spite of the fact that the Poles are less than 25 per cent of the population?" In the Prussian province of. Posen the Polish population numbers slightly over 60 per cent, in the province of West Prussia the Poles number about 33 per cent. Can there be the slightest hope that a decision based on a general plebiscite taken in these two provinces as units would prove satisfactory to the respective minorities? Let it be supposed plebiscites were taken locally and a racial division on local lines were clearly established, would any practical statesman propose the annexation of non-contiguous districts to the

2 The Nation, New York, Jan. 17, 1918. 
respective states of their race? ${ }^{3}$ The same conditions, probably still more complicated, confront us in the Silesian, Bohemian, Hungarian, Rumanian, Austro-Italian, and ItaloJugo-Slav situations."

The Nation concludes that "such considerations emphasize the statesmanlike programme put forth by the British Labor Party, which would leave the difficult problem of self-determination of peoples to be worked out at leisure under the super-national authority which it demands as one of the essential conditions of world-reconstruction."'s

There seems little likelihood that any super-national authority could, without the utmost good-will of the states concerned, unravel such entanglements to the lasting satisfaction of all concerned, while, on the other hand, a little good will on the part of the states involved would enable them to pacify their foreign enclaves through a liberal policy, guaranteeing liberty of language, cultural developnent and granting the greatest possible measure of local self-government. Enforced expatriation would be a measure too radical and too impracticable to be thought of.

A second phase of the difficulties involved in the successful application of the plebiscite as the means of self-determination has manifested itself in the Russo-German wrangle over the Baltic provinces. In the peace programme of December 25, I9I7, Germany had professed adherence to the principle of self-determination. ${ }^{6}$ But while Russia demanded immediate evacuation of the territories in question and a popular vote on the issue of separation after evacuation has taken place as the only way to insure real self-

${ }^{3}$ Through the cession of Danzig and the greater part of West Prussia the Treaty of Versailles has in fact created a situation in which the province of East Prussia would be geographically severed from the rest of Germany, although retaining its political connection.

* Fairly accurate details of the racial configuration of the Central States of Europe, the Baltic provinces, and Turkey may be found in L. Dominian, The Frontiers of Language and Nationality in Europe, New York, 1917.

${ }^{5}$ For complete programme see The New Republic, Feb. 16, 1918.

6 See below, p. I78. 
determination, ${ }^{7}$ Germany held that these provinces, as far as they had, through their legislatures, declared their wish for independence and separation from Russia, already had resorted to the principle of self-determination and thus had already determined what had been open to decision. ${ }^{\mathrm{s}}$ Aside from the additional factor of military occupation the difference between Russia and Germany then seems to have been that of a choice between self-determination by indirect vote in the legislature or by universal direct suffrage. In fact, the reply of the Central Powers to the Russian proposals for the settlement of the Baltic question stated that "... the setting up of a referendum appears to be impracticable," and that " in the opinion of the Allied Delegation, it would suffice if a vote, on a wide basis, were taken from an elected and supplemented representative body." The reply pointed out to the Russians that the separation from Russia of Finland and the Ukraine was "brought about not in the way of a referendum ... . but by means of resolutions by a national assembly elected on a wider basis."”

If a direct popular vote on the issue of separation from Russia were taken, the result, in whatever form, could hardly be questioned by either party since the race issue would in such a case be practically non-existent, the Germans being, even in Courland, the most German of all these provinces, less than Io per cent of the population. ${ }^{10}$ If, however, the issue be decided by a representative vote, an anti-Russian decision could be open to the charge of

7 Proceedings of the Brest-Litovsk Peace Conference, .... November 21, 1917-March 3, I9I8 (U. S. Dept. of State), Washingtion, Govt. Printing Office, I918. See also New York Times Current History, vol, vii, part 2, pp. $280-202$.

8 Proceedings of the Brest-Litovsk Peace Conference, sessions of Dec. 28,1917 , and Jan. $11,1918$.

9 Ibid., session of Jan. I4, I9I8. At the same occasion the Teutonic Delegations made the following statement: "The assertion that the right of self-determination is an attribute of nations and not of parts of nations is not our conception of the right of self-determination. Parts of nations can justly conclude independence and separation. ... Courland, Lithuania, and Poland also constitute national units from an historical point of view. ..."

${ }_{10}$ See note 2 and corresponding text. 
German influence, pressure, force or bribery among the representatives voting. A drastic incident of such a character we have in the charges laid against the members of the Danish Landsthing, who, in I9O4, voted against the sale of the Danish West Indies to the United States. "There were in the Landsthing," so W. F. Johnson writes in The North Amcrican Rceicai,"1 "many nembers who were susceptible to German influence. Some were half German, or were closely related by marriage to German fanilies. Others owned estates in Schleswig and Holstein, the Danish provinces now held by Prussia. Others were deeply interested in trade with Prussia. So, after many weeks of intriguing, thirty-three members of the Landsthing, making exactly one-half of that body, were prevailed upon to vote against ratification." His assertion that universal regret over the result was widespread in Denmark seems to be borne out by the fact that in 1916 the Landsthing approved the purchase and a popular vote taken on the issue produced 283,694 votes in favor of and 157,596 against the sale. ${ }^{12}$ From such a result we may well infer that if a popular vote had been taken in 1904, it might have approved of the purchase of the Islands at the same time that the Landsthing voted adversely.

However, the possibility of influencing, by bribery or by other means, the members of legislative bodies exists everywhere and at all times; this is as true under normal conditions as during the stress of a national crisis. There seems to exist actually less danger of such corruption when the legislature votes on the question of a change of government, of peace and war, separation, or fusion, than when it votes on internal, social or economic measures, for the simple reason that in the former instance bribery might be treated as high treason, conviction entailing ignominy or death. While a legislature may be subject to forceful dissolution, it cannot be cajoled into doing the bidding of or

11 The North American Review, Sept., 1916, pp. 389-390.

12. See above, p. I26. 
be deceived into falling into the traps set by an ambitious and scheming ruler, with the same case with which this can be achieved in the case of an unsuspecting and less informed mass of voters. When Louis Napoleon, shortly after his election to the presidency in 1848 , set out to increase his authority and to prepare for the prolongation of his rule and for what followed, he realized that he would have to meet the resistance of the Assembly and the opposition of his officers of state, of the army, and of the population. His chief concern was the Assembly. Hence, his first move was to discredit the legislature in the eyes of the country. ${ }^{13}$ Thus, in the early part of the year 1850 , he promulgated a law, presented by himself to the Assembly and passed by that body, which modified the existing system of universal suffrage by means of extraordinary demands of domicile. He calculated, and correctly so, that a sudden and adroitly worded public request from the President, demanding the repeal of such a restriction, would surely place the executive before the land as the defender of popular rights and would prove embarrassing to the Assembly which had written it into the statute book. According to de $\mathrm{La}$ Gorce, ${ }^{14}$ only five persons were initiated into the schemer's ambitious plans: General Saint-Arnaud, Minister of War, who would see in the dispersing of Parliament and in the usurpation of power but an enterprise still more spectacular than his former expeditions to Africa; de Morny, hero of the salon and the bourse, future Minister of the Interior; de Maupas, prefect of police, very young, devoted to any cause in which the gain would measure up to the risk; Moquard, secretary to the chief executive; and de Persigny, ami des mauvais jours. These men being won for the Napoleonic cause, the citizens of Paris awoke on the second of December, I85I, the anniversary of the battle of Austerlitz and the crowning of the first Napoleon, to find the walls placarded with proclamations informing them that "the

${ }^{13}$ La Gorce, Histoire du second Empire, vol. i, pp. 3-4.

14 Ibid., vol. i, pp. 4-5. 
Assemble was dissolved, that universal suffrage was reestablished, that a state of siege was in force," that "the principles of 1789 were to remain the basis of our public law," that "the last word was to be spoken by the nation to be consulted through the voice of the plebiscite." The issue was thus sufficiently beclouded as far as the masses were concerned. To this was added the element of force. Instructions were sent out to the prefects to "replace immediately all hostile or suspected functionaries, to dissolve hostile municipal councils, not to tolerate any discussion of things that had happened, to demand the submission of the proofs of articles for the press." In Paris public and private buildings were searched for arms and dangerous literature. Even people under the least suspicion were taken into custody, filling prisons and forts. Napoleon well knew that the Assembly had no doubts about the real meaning of the proclamation. Thus, before the next dawn, sixteen of the most hostile members of the Assembly were arrested in their homes, among them Thiers. The rest were dispersed during an attempt to gather at the Palais-Bourbon. Two hundred and eighteen were taken into custody during the following night. ${ }^{15}$

The result of the plebiscite of December 20, I85I, fully justified Napoleon's expectations. Of a total of $8,079,953$ votes cast, $7,439,216$ voted in the affirmative on a ballot which stated that "the people want [veut] the maintenance of the authority of Louis Napoleon and delegate to him the powers required to create a constitution on the basis proposed by his proclamation of December the second."'

It may be maintained that such methods of force and compulsion can no longer be applied in a peaceful and wellgoverned commonwealth. But even to-day a territory under the military occupation of the victor, who himself demands its annexation, can hardly be styled a peaceful and wellgoverned commonwealth. It would of necessity follow that

${ }^{15}$ Ibid., vol. i, pp. 5-6; see also La Gorce, Histoire de la seconde République française, vol. ii, books $x x-x x i$.

${ }^{16} \mathrm{La}$ Gorce, Histoire du second Empire, vol. i, p. 12. 
a plebiscite, held in whatever form, should not take place until the territory in question is once more in a state which would justify its being called peaceful and well-governed.

Eliminating from any plebiscite held on the issue of the transfer of territory the element of force and bribery, we still must admit the possibility of danger in the form of popular illiteracy and ignorance in matters of politics. ${ }^{17}$

No doubt, most peoples have, on one occasion or other, been confronted with the problem of voting on laws and ordinances, or on amendments to laws and ordinances, which not two of the best legal minds have been able to interpret to each other's satisfaction. On the other hand, to decide whether one wishes to remain with Russia, or Germany, whether one wishes to be independent or to assume a foreign allegiance, must be admitted to be an infinitely more simple process, running less danger of surpassing the average intelligence of the normal man or woman.

Assuming then, in the case of the transfer of territory, the feasibility of a popular vote on a clear and unambiguous issue, without military and police interference and without bribery, it seems that the ultimate result of the vote would be equally representative whether registered on the basis of universal suffrage, by an assembly elected on the issue to be decided, or by an assembly vote afterwards ratified by universal ballot. Questionable could be only the decision of an assembly elected on another, an unconnected, or an intentionally beclouded issue.

There remains to be considered the direct vote on a restricted franchise or the vote of a legislature elected by limited ballot. Writing of Napoleon Bonaparte's constitution of the 22 frimaire of the year VIII, submitted to the plebiscite of December, I793, and put into effect before the end of the voting, Aulard states that "in effect universal suffrage, while being reestablished, was being annihilated at

${ }_{17}$ On this subject see E. Vacherot, La République constitutionelle et parlementaire, in Revue des deux mondes, Nov. 15, 1879, vol. xxxvi, especially' pp. 252-254. 
the same time. ${ }^{18}$ "It was being reestablished inasmuch as henceforth all Frenchmen, twenty years of age, and domiciled for one year, except paid domestic servants, are citizens and possess the right to vote." But it was in fact annihilated by such ingenious dispositions as these:

All citizens of each communal arrondissement reduce their own number to one-tenth in designating through their vote "those among them whom they consider the best suited to conduct public affairs." This one-tenth forms the liste communale or the liste d'arrondissement from which the corresponding public functionaries must be chosen. The citizens included in these communal lists of the various departments again reduce themsclves to one-tenth, thus producing the liste départemcutale from which must be chosen the officers for the department. All the departmental lists once more are reduced to one-tenth and thus form the liste nationale of those eligible for public national functions, e.g., the functions of deputies, tribunes, etc.

But Aulard continues:

For ten thousand, assuming that number, to be forced to designate at least one thousand, is really not designating any one . . . because the demand for such a large number does not permit of any choice at all; in order to arrive at one thousand one had to designate all and everyone who was not illiterate. At best one could exclude some individuals not fitted for position, but there was no way of excluding from the list an entire faction, or an opinion. ${ }^{18}$

However, this was more than one hundred years ago. Still, England, until well into the XIX century, and Prussia and Saxony, until the reforms of the year I9I8, possessed restricted franchises scarcely superior to the one described by Aulard.

The restrictions of the French franchise of 1799, and those of the later English, Prussian and Saxon systems, were based on the material distinctions of property or income, conditioned by internal policies, chiefly with the desire to protect prevailing social and economic principles against undesirable evolutionary or revolutionary changes. Such considerations, however, can not be adduced in the case of a vote on the transfer of territory entailing a change of allegiance. If a plebiscite in such a case is to be held, persons capable of earning their own living should be con-

${ }^{18}$ F. V. A. Aulard, Histoire politique de la Révolution française, Paris, 1901, p. 706 .

19 lbid., pp. $706-707$. 
sidered qualified to express themselves on such an issue, if they desire to do so.

So far the consideration of the subject has necessarily proceded on the assumption of an analogy of cause and effect between the majority vote and rule in matters of internal government and a majority decision by the plebiscite in the determination of sovereignty. Such analogy, however, does not exist. ${ }^{20}$ On the contrary, there is this fundamental difference: the decision on matters of political interest in the internal affairs of a state is, as a rule, only temporary; the elections are periodical and a different political configuration can at any time convert a majority into a minority and vice versa. Even where decisions are more or less permanent in case of a direct or indirect vote on laws, or the acceptance or amendment of a constitution, the law can, by the same legal process, be repealed or amended and the constitution changed to meet new requirements. Change of sovereignty by enforced transfer of territory from one state to another is considered and even by the treaty effecting the transfer stipulated to be permanent. By a plebiscite, deciding in favor of such a transfer by a simple majority, fifty-one out of one hundred voters can permanently force the remaining forty-nine into an objectionable allegiance. ${ }^{21}$ A tie vote would prevent a decision unless some other arbitrary way of breaking the tie were resorted to.

Be it assumed that a territory has thus, by a majority vote of $5 \mathrm{I}$ to 49 per hundred voters, severed its connection from its parent state: if the 49 per cent of dissenters live together in a district contiguous to the mother country, they should be permitted to retain their old political connection. Or they may, while living together, inhabit a stretch of country which, by the secession of the larger section, would

20 See also Stoerk, pp. 64-67.

21 "The plebiscite means subjection, subordination of a minority to a majority. A million citizens dispose of 800,000 others (without counting the women and children), thwart their interests and oppose their desires" (Bonfils, no. 570). 
be separated geographically from the parent state. A solution would be difficult to find. It would have to be either subnission to the new state of affairs, or, assuming the consistent application of the principle of self-determination by way of the plebiscite, separation from the seceding territory. In the last case there are three possibilities of action for the dissenting minority in the seceding section: (I) demand for complete independence, (2) return to the political union with the mother state though separated geographically from the latter, and (3) affiliation with or incorporation in another neighboring state for the sake of protection or for other reasons.

There is also a possibility, or rather a probability, that the dissenters are scattered all over the seceding territory in more or less all of its localities and country districts. In this case the 49 per eent, being forced against their will into secession, will either quickly submit to the change, or they will set to work to convert their minority of 49 into a majority of $5 \mathrm{I}$ and then to reverse the decision of secession into a vote for reannexation to the parent state. This would, of course, be made more difficult if the secession from the mother country had at the same time, or afterwards, been followed by a decision for annexation to another state.

The examples here adduced, complicated as they seem to be, are, in reality, very simple. It requires no great amount of imagination to see that in the seceding territory there may be even more than two factions, all with different aims; or that after the assumed separation of the dissenting minority from the seceding majority minorities remain in both who again may claim the application of the principle of self-definition for themselves. It can readily be scen that with a consistent application of the doctrine of selfdefinition, we may in certain sections of Europe return to communal autonony as the only solution of a complex racial tangle. Where a final disintegration into clear-cut communal divisions on racial or political lines would not be 
possible, we would have to accept perpetual strife and revolution as the alternative.

To what extent a two-thirds, three-fourths or a still larger majority would eliminate the dangers of continued demands for recognition by dissenting minorities, is a question which permits of no definite answer. The only statement that can be made with assurance is that nothing short of an effective near-unanimity can give a satisfactory solution on a basis of a decision by direct or indirect popular vote. Such an effective near-unanimity may be defined as a majority which, without any recourse to compulsory methods, proves itself able to gain the expressed or tacit consent of the minority to submit to the decision made.

In the last decades the institution of option has, in the cases of transfers of territories, frequently been applied in order to overcome, as far as possible, the opposition of the inhabitants, or of the element most hostile to the change of allegiance enforced upon them.

Bonfils and Rivier in France and Stoerk and Ullmann in Germany, while refuting the principle of the plebiscite as a practical means of overcoming the difficulties connected with the cession of territory, see the solution of this question in the practice of giving the inhabitants of the territory the option of accepting the new enforced sovereignty or of retaining their old allegiance. ${ }^{22}$ In his Option und Plebiscit, Stoerk gives an historical account of the principle of option as practiced in the past. He begins his study with a consideration of the right of emigration. In the Peace of Augsburg of I555 and in the Treaty of Westphalia in 1648 the jus cmigrandi was granted to religious dissenters. The Peace of Augsburg had established for the German states the principle of the cuins regio, eius religio. But the same peace treaty gave the Protestant population the right of emigration in case they refused to return to the Catholic faith, to be forced upon them by their princes. The

22 Bonfils, no. 57I; Rivier, vol. i, pp. 204-208; E. von Ullmann, Völkerrecht, Tübingen, 1908, p. 358 . 
same right respectively was granted to the Catholic inhabitants of the territories where the official cult was that of the Protestant ruler. Stoerk denies to these cases the character of precedents for the modern practice of option. The motive prompting the choice of emigration, rather than of remaining under macecptable conditions, was religions belief, not political attachment to the state in question.".3 The first case of option, as lefined, he sees in the Peace of Hubertsburg, between Frederic II of Prussia and Maria Theresa of the Germanic Empire in the year 1763 , at the end of the third Silesian, the so-called Seven Years War." Already Article III of the Peace of Berlin of July 28, I 742 , terminating the First Silesian War, provided for the territories ceded to Prussia the choice of emigration, with the time allowance of five years. In Article $X$ of the Treaty of Hubertsburg of 1763 , the right of free emigration from the city and comnty of Graz ceded to Prussia was granted. This emigration had to be effected within two years. No emigration tax was to be levied. ${ }^{25}$ The request for enigration within a time limit of from one to two years has become the basic principle of the options granted in most of the treaties of cession since that time. The first use of the term option is found, according to Stocrk, in the Treaty of Elisson, concerning the frontier rectifications between France and the King of Spain in the year 1785 . Articles VII of this Treaty reads: "Afin d'éviter tout préjudice aux sujets des deux souverains... il a été convenu qu'ils auront une entière liberté de rester sous la domination dans laquelle ils se tronvent, on de passer dans celle du souverain dans le territoire du quel se trouveront leurs possessions. Pour l'option

23 Stoerk, pp. 94-95.

24 Art. xvii of the Treaty of Ryswick of I697 gave to the inhabitants of Strassburg the right of emigration with their belongings and without an emigration tax. This grant has been recorded by Calvo as the first instance of a clause of option (Wambaugh, p. 4, note 4). But, as Stoerk points out, this concession can not be considered as a case of option for the reason that seventeen years had elapsed since France had actually possessed herself of Strassburg and had, during those years, held the inhabitants in an enforced allegiance (Stoerk, pp. 97-08, note 3 ).

25 Ibid., pp. $96-97$. 
entre ces deux partis, il leur sera accordé dix-huit mois de delai. ..."26

We have here then for the first time the expressed recognition of the principle of sovereignty and allegiance as the guiding motive for the granting of the right of emigration. With the advent of the French Revolution and the recognition by revolutionary France of the principle of national self-definition by way of a plebiscite the majority decision was made binding on the minority in the territories thus annexed to France. In the annexations of the period of I798-1805, France accepted the grant of option. In the Treaty of January, I798, by which the inhabitants of the German city of Miilhausen were declared "born Frenchmen," the right of emigration was given to those who refused to accept the rule of France. The decision for emigration had to be reached within one year, while three years were allowed to carry the decision into effect. ${ }^{27}$ The same provision was made in the Treaty of April 26, I798, by which Geneva was annexed to France. ${ }^{28}$ However, the annexations during the time of the Consulate and the Empire were effected without consideration of the wishes of the population and without option. ${ }^{29}$

The principle of option was recognized in the territorial settlement of the second Peace of Paris of November 20, ISI 5. Article VII reads:

In all countries which shall change Sovereigns, as well in virtue of the present Treaty as of the arrangements which are to be made in consequence thereaf, a period of six years from the date of the exchange of the Ratifications shall be allowed to the inhabitants, natives or foreigners, of whatever condition and nation they may be, to dispose of their property, if they should think fit so to do, and to retire to whatever country they may choose. ${ }^{30}$

The Treaty of Versailles of 1919 has embodied the principle of option in favor of Germany in transfers of terri-

\footnotetext{
${ }^{26}$ Quoted from Stoerk, p. I0o.

27 Stoerk, p. 108.

28 Ibid.

29 Ibid., p. 109.

${ }^{30}$ Hertslet, vol. i, p. 348 .
} 
tories from German sovereignty to Belgium, Denmark, Poland, and Czecho-Slovakia. No option is provided for in the cessions of Danzig, Memel, and Alsace-Iorraine. In the case of Alsace-Lorraine, Germany agrees to receive into her territory all Germans to whom France shall refuse French nationality and donicile.

Whatever the merits of this form of option be, the emigration stipulated is not, as Stocrk holds, voluntary, but enforced. While as a rule a more or less limited time is allowed for the disposal of immovable property, the element of violence to the human attachment to soil and home, to friends and relatives, remains. Furthermore, it is clear that a very large percentage of those concerned are prevented from taking advantage of opting under the given conditions on account of economic and other reasons. The Treaty of Frankfort of $I \delta_{7}$ I provided for option in favor of France on condition of enforced emigration after two years. Not less than 45,000 persons availed themselves of the privilege; nevertheless, after forty-five years of German sovereignty, thirteen per cent of the population have preserved their French language and racial characteristics. ${ }^{31}$

Option with compulsory emigration may be at the present time the one measure giving the greatest amount of consideration to the natural rights of men; but in case of an enforced cession which has become inevitable, it offers no more of a solution to the ethical issues involved than does the application of the plebiscite in the same instance or in voluntary secession.

Option without the demand for emigration seems to have been applied so far only in the case of the settlement of the Spanish-American war in the cession by Spain to America

31 The Encyclopædia Britannica, IIth ed., Alsace; Meyers Grosses Konversationslexikon, 6th ed., Elssass Lothringen, gives the number of the emigrants as 50,000. Stoerk gives the following figures of the opting: total population $1,517,494$; an actual declaration of option was made: before German authorities by 159.740 , before French authorities 378,777 (Stoerk, p. 172). For the text of the treaty see Hertslet, vol. iii, p. 1956, Art. ii. 
of the Philippine Islands. According to Article 9 of the Treaty:

Spanish subjects, natives of the Peninsula, residing in the territory over which Spain by the present Treaty relinquishes or cedes her sovereignty, may remain in such territory or may remove therefrom, retaining in either event all their rights of property..... In case they remain in the territory, they preserve their allegiance to the Crown of Spain by making, before a court of record, within a year from the date of the exchange of ratifications of this Treaty, a declaration of their decision to preserve such allegiance. . . .32

By the "Protocole" of May 29, I900, the time limit for the declaration was extended six months. ${ }^{33}$

There is one last, and possibly the greatest stumbling block to the plebiscite as the successful expression of national self-determination. The historical survey of the plebiscites of the past has revealed the great outstanding fact that the principal of national liberation through the plebiscite has been active not only in the creation of great powers, but also in the diminution and dissolution of others. In fact any acquisition of territory, whether by force of conquest or as a peaceful accession by means of a recognized plebiscite, signifies practically always a loss of territory to some other state. It is in this circumstance that the greatest opposition to the universal sanction of the principle of self-definition as well as of the consequent and consistent employment of the plebiscite as its mode of expression must be sought.

The cases where in the past the plebiscite, referendum, or representative vote has been used in the disruption of existing political state units are the secession of the Southern States from the North American Union, the secession of West Virginia from the State of Virginia, the dissolution of the union of Sweden and Norway. In the last two cases the result of the plebiscites were recognized by Virginia and by Sweden. In the first case, the secessions, in spite of

32 Compilation of Treaties in Force, Prepared under Resolution of the Senate, of February I I, 1904, Washington, Govt. Printing Office, I904, pp. 725-726.

33 Ibid., p. 728. 
popular, direct, or indirect votes, were opposed by the sword, and the seceding states forced to rescind their decisions. In both instances, however, the motive for the difference of attitude towards the seceding units was based on state policy and considerations of the legality on the principles of international law of the secession movements as such, ${ }^{34}$ rather than on favorable or unfavorable opinions regarding the plebiscites as justifying the demand for secession.

The plebiscites in the case of West Virginia and in Norway had shown a practically unanimous vote, and nothing short of war could have preserved the status quo. The possibility of defeat and. on the other hand, the chances of continued opposition of a sectional, hostile population in case of victorious war, against the certainty of a gratified and friendly neighbor, decided the issue in Norway which, being tied to Sweden in a 'real union,' was thus not an integral part of Sweden as a nation. Virginia was not an independent State but only one of a union of States. By Article IV, Sect. 3, of the United States Constitution it is stipulated that "no new States should be formed or erected within the jurisdiction of any other State... without the consent of the Legislatures of the States concerned as well as of the Congress." Since it was the section separating from Virginia which remained loyal to the Union, the latter had every reason to be favorably inclined towards the new State. The secession of the rebellious Southern States from the United States however involved the very existence of the Union as such in so far as it brought to a climax the issue of states' rights and federal rights, of state sovereignty and federal sovereignty, the question whether the states had a right to secede or not. The principle of self-preservation forced the Union to a policy of war which decided the issue against the secessionists.

No less is it a question of a wise state policy on the part of the acquiring state to sanction or even demand a plebi-

34 See above, pp. I19-123. 
scite in the annexed territory if by such an act it is sure to establish an outward sign of the desire or willingness of the inhabitants to be annexed.

On the other hand, the same motive would prompt a policy of opposition to any public expression where and when the result would be in doubt or be expected to be negative. Where, however, in cases of doubt or certain hostility of the population concerned, state policy has found it advisable to consent to the fictitious promise of a popular vote, reasons of state have made imperative the adoption of measures which would tend to assure a favorable result of the plebiscite. The historical review of the plebiscites of the past offers sufficient material of illustration of this.

If it is considered good policy on the part of the acquiring state to favor a plebiscite where it promises approval of its acquisition, it must be bad policy for a state to permit a plebiscite where it would reveal a strong sentiment for cession or secession of part of its domain. The same policy would respectively dictate the inclination or disinclination of a state to subscribe to the theory of popular consent as a measure giving validity to the territorial changes contemplated or feared. It is thus easy to understand that a multinational, or multi-racial, state like the former Austro-Hungarian Empire, or Turkey, or Germany with the Polish, the Danish and the Alsace-Lorraine problem, or Great Britain with her colonies and dominions and hostile Ireland, or in fact any federated state body, should in principle or practice be opposed to the doctrine of popular consent. It is this that the French jurist alludes to when he writes that "the principle of the plebiscite, if once adopted, entails grave and dangerous consequences. Admitting the necessity of the popular suffrage in the case of voluntary or enforced cession of a province to another state, we cannot refute the pretention raised by a part of a state to separate absolutely from the other parts to join another state or to render itself independent." He asks, how is a fraction of a state, having changed its mind, to be retained with the national union, as 
long as $[$ dis] this change of mind can be demonstrated by vote of the citizens? For, if the plebiscite possesses alone the efficacy of dissolving political ties, then it must alone be sufficient for this task." 35 Referring to the American secession movement he concludes that the Northern States did not hesitate to fight for the maintenance of the Union, because they possesed the conscionsness that tradition and the future of the country imperiously demanded such action..$^{36}$ The same view is maintained by Stoerk, who states that "here we have reached the heart of the question, which reveals the principle of the plebiscite as hostile to the state and as theoretically untenable-because its first and next consequence is the dissolution of all state existence." ${ }_{37}$

${ }^{35}$ Bonfils, no 570 .

36 Ibid.

3i Stoerk, p. 67. 


\section{CHAPTER VIII}

The Plebiscite in International and Constitutional LAW

The transfer of territory from one state to another is a matter of interstate, or international, relations. Such relations are subject to, and are regulated by, that body of rules by which the civilized nations have in common agreed to govern their mutual intercourse. The plebiscite in the transfer of territory must, therefore, be considered in its relations to these rules.

While the plebiscite has been considered in its international aspects by a long list of commentators, of advocates and opponents, ${ }^{1}$ the institution has, nevertheless, found little space in our standard text books on international law. The prevailing opinion expressed before the World War was to the effect that the rules governing the intercourse of states do neither demand nor recognize the universal application of the plebiscite in the determination of sovereignty. W. E. Hall, for instance, speaks of the idea that the exercise of the right of alienation is "subject to the tacit or express consent of the population inhabiting the territory intended to be alienated," as a misapprehension. Thus he writes:

The doctrine appears in two forms, a moderate and an extreme one. In its more moderate shape it appears to come to little more than a denial that title by cession is complete when the ceded territory has been handed over by the original owner to the new proprietor, peaceable submission by the inhabitants being necessary to perfect the right of the latter; but it is occasionally declared that the cession of land cannot be dissociated from that of the people who live and enjoy their political right's upon it, that " a people is no longer a thing without rights and without will," that its consent, if

1 A fairly complete list of the advocates and the opponents of the plebiscite is given by Freudenthal, pp. 54-56. The list has been brought up to date by Wambaugh, pp. 21-30. 
not otherwise proclaimed, must be testified by a vote of the population or its representatives, and that international law has adopted this principle by its practical recognition in the Treaty of Turin, which regulated the cession of Savoy to France, in the Treaty of London, by which the Ionian Islands were ceded to Greece, in the Treaty of Vienua, which stipulated for the eventual cession of Venetia to Italy, and in that portion of the Treaty of Prague, which referred to Northern Slesvig. For an answer to this doctrine in its extreme form it is only necessary to traverse the allegation of fact. The principle that the wishes of a population are to be consulted when the territory which they inhabit is ceded has not been adopted into international law, and can not be adopted into it until title by conquest has disappeared. The pretension that it was sanctioned by the treaties cited has an air rather of mockery than of serions statement, when the circumstances accompanying the cession of Savoy and Nice are remembered, and when the only treaty of the number, the breach of which opportunity and desire combined to render possible, remained nnobserved and has finally been cancelled. As to the milder form of the doctrine, it is only to be said that states being the sole international units, the inhabitants of a ceded territory, whether acting as an organized body or an unorganized mass of indivichals, have no more power to confirm or to reject the action of their state than is possessed by a single individual. . . .

A. S. Hershey is equally emphatic when he states that " it is certain that the legal validity of a title based on cession does not require such action [the holding of a plebiscite or vote in Assembly] on the part of the inhabitants of the ceded territory.", 3 L. F. L. Oppenheim considers it " doubtful whether the Law of Nations will ever make it a condition of every cession that it must be ratified by a plebiscite." He grants that "the necessities of international policy may now and then allow or even demand such a plebiscite," but he adds that "in most cases they will not allow it."4

In the light of the expressions of eminent authority we understand why, in 1867 , Secretary of State W. H. Seward gave only his unofficial consent to the plebiscite which was to decide whether or not the inhabitants of the islands of St. Croix and St. John wished to be annexed to the United States. He apparently did not wish to recognize the principle of the plebiscite in the transfer of territory nor to create a precedent through its recognition which might prove embarassing

\footnotetext{
${ }^{2}$ Hall, pp. 46-47.

3 Hershey, p. 184

4 Oppenheim, vol. i, p. 274.
} 
to the United States in future transactions of a similar nature. The resuit of the plebiscite, a vote of I,244 against 22 in favor of annexation, ${ }^{5}$ seems to indicate that the favorable outcome of the plebiscite could safely be anticipated, and thus its application with unofficial consent could at least do no harm. But there can be no doubt that even this unofficial consent would not have been given if the result had been in any way in doubt. W. F. Johnson seeks to explain Seward's stand on the basis of constitutional rather than international law. He admits that "Seward was following the precedents established by Jefferson in the purchase of Louisiana and by John Quincy Adams in the annexation of Florida, under which the people of those territories were not consulted any more than cattle would be over the sale of their pasture," but he continues, "this, at least in Seward's case, was not an expression of disregard for popular rights. It was simply intended to forfend against any possible demand for Statehood by the annexed territory. If the people of the islands were consulted on the question of annexation, he cogently argued, they could logically demand to be consulted concerning the status of the islands after annexation. He preferred to follow the old precedents, and thus to be able to insist upon the constitutional rights of Congress to fix the status of the islands and to govern them as it pleased, without consulting anybody. So while he was reluctantly willing that a plebiscite should be taken, he insisted that it should not be mentioned in the treaty or be recognized in any way by the Government of the United States." In the absence of documentary evidence bearing out Johnson's interpretation of the motives which prompted Seward to refuse official recognition of the plebiscite, it seems just as plausible to adhere to the view that he might have been led by the same considerations which moved Secretary of State John Sherman, in his reply of August 14, 1897, to the Japanese Minister, Toru Hoshi,

${ }^{5}$ W. F. Johnson, The Story of the Danish Islands, in The North American Review, Sept., 1916, pp. 384-385; see also Wambaugh, p. 15 I. 
who had suggested that a plebiscite be taken in the Hawaiian Islands on the question of annexation to the United States. This is in part the reply as quoted from Moore's Digest of International Law:

In referring to the sentiments of the population of Hawaii, you say: "It is understood that only a small fraction of their number favor annexation." You omit to state how this understanding has been ascertained, nor is it clear what is the purpose for which the statement is introduced.

It can not be that one so well informed in the history of international relations as Count Okuma could have wished to suggest thereby the propriety of appealing from the action of the Government to "the population." In international comity and practice the will of a nation is ascertained through the established and recognized government, and it is only through it that the nation can speak. This is shown in the relations of the United States with Japan. The first intercourse of this Government with the Empire was had with an authority which held a divided, if not disputed, sovereignty. Later, when all power and legislation was centered in the Emperor, this Government recognized him as the sole exponent of the public will. When parliamentary government was established the changed relation was accepted by the United States. No inquiry was thought proper to ascertain whether these various changes received the sanction of "the population." The present Government of the Hawaiian Islands, recognized by Japan and other countries, has been in existence for a series of years, during which time public peace and social order have been maintained, and the country has enjoyed an era of unprecedented prosperity. The Government of the United States sees no reason to question its complete sovereignty, or its right to express the national will. ${ }^{6}$

The same principle was asserted in the Memorandum of the American Peace Commission of October 27, 1898, at the conclusion of the Spanish-American war, where it is stated that "much less do the American Commissioners maintain that a nation can not cede or relinquish sovereignty over a part of its territory without the consent of the inhabitants thereof. ..."?

When during the Franco-Prussian war Thiers visited the capitals of the great neutral Powers of Europe in order to solicit their support for France and particularly against the annexation of Alsace-Lorraine, Gladstone " could not uncherstand how the French protests turned more upon the inviolability of French soil than on the attachment of the

${ }^{6}$ Quoted from Moore's Digest, vol. i, p. 274.

7 Quoted, ibid., vol. i, p. 368. 
people of Alsace and North Lorraine to their country. The abstract principle he thought peculiarly awkward in a nation that had made recent annexations of her own." In a statement to the English Cabinet he urged that "it cannot be right that the neutral Powers should remain silent, while this principle of consulting the wishes of the population is trampled down, should the actual sentiment of Alsace and Lorraine be such as to render that language applicable." Morley, Gladstone's biographer, quotes part of a letter sent by Gladstone to Mr. Bright, who was prevented by illness from attending the Cabinet meeting. In this letter Gladstone writes:

I send for your private perusal the enclosed mem. which I proposed to the cabinet yesterday, but could not induce them to adopt. It presupposes the concurrence of the neutral Powers. They agreed in the opinions, but did not think the expression of them timely. My opinion certainly is that the transfer of territory and inhabitants by mere force calls for the reprobation of Europe, and that Europe is entitled to utter it, and can utter it with good effect. ${ }^{9}$

However, Europe did not utter its reprobation, nor did Mr. Bright agree with Gladstone. ${ }^{10} \mathrm{He}$ favored the principle of territorial inviolability as did Thiers himself who, in 1867 , had expressed his views before the French Assembly to the effect that "the new principle of popular consent is an arbitrary principle, very often deceptive, and that at the bottom of it is nothing but a principle of perturbation when applied to nations." 11

In criticism of a memorandum to the neutral powers the Duke of Argyll, writing to Gladstone, expressed what Morley considers as perhaps the general view. The Duke's stand in the matter of annexation of Alsace-Lorraine by Germany is thus stated by Morley:

He had himself never argued in favour of the German annexation of Alsace and Lorraine, but only against our having any right to oppose it otherwise than by the most friendly dissuasion. The

${ }^{8}$ John M. Morley, The Life of William Ewart Gladstone, New York, I903, vol. ii, pp. 346-347.

9 Ibid.

10 Ibid.

11 Quoted from Rivier, vol. i, p. 2II. 
Duke lield that the consent of a population to live under a particular government is a right subject to a great many qualifications, and it would not be easy to turn such a doctrine into the base of an official remonstrance. After all, he said, the instincts of nations stand for something in this world. The German did not exceed the ancient acknowledged right of nations in successful wars, when he said to Alsace and Lorraine, "Conquest in war forced upon me by the people of which you form a part, gives me the right to annex, if on other gromuds I deem it expedient, and for strategic reasons I do deem it."12

Equally outspoken against Gladstone's stand was Lord Granville. ${ }^{13}$

Thus, leading English statesmen approved, and neutral Europe sanctioned, the annexation of Alsace-Lorraine to Germany without the consent of the inhabitants. They approved and sanctioned this alienation apparently on the principle of title by conquest. ${ }^{14}$ The United States, as we have seen, emphatically expressed in 1867 its adherence to the principle and practice of annexation without the consent of the peoples thus annexed, and reasserted its stand as late as 1897 and 1898 .

About two decades later, on January 22, 1917, President Wilson declared in a message to the Senate that: "No peace can last, or ought to last, which does not recognize and accept the principle that governments derive all their just powers from the consent of the governed and that no right anywhere exists, to hand peoples about from sovereignty to sovereignty as if they were property." He has repeated this dogma in a form more terse and specific on many later occasions. On April 2, 1917, he prociaimed to

12 Morley; vol. i, pp. 347-348.

13 Ibid. In 1890 at the occasion of the proposed cession of Heligoland by England to Germany, Gladstone opposed the plebiscite suggested by De la Warr, Lord Rosebery and others. See above, p. II 2 .

${ }_{14}$ Speaking of the principle of title by prescription, Hall thinks that "if the severance from France of Alsace and Lorraine had been looked upon as an instance of naked conquest. it is probable that European public opinion would have been greatly shocked by the measure." He seems to make the point that in this case the principle of nationality has lessened the value of the old principle of title by prescription under which, as we must infer, France was holding the old German territories (Hall, p. I20, note I). 
the world that America fights "for the rights of nations great and small and the privilege of men everywhere to choose their way of life and obedience." On February i I, I9r8, he said in Congress:

Peoples and provinces are not to be bartered about from sovereignty to sovereignty as if they were mere chattels and pawns in the game. ... Peoples may now be dominated and governed only by their own consent. Self-determination is not a mere phrase. It is an imperative principle of action, which statesmen will henceforth ignore at their peril. We cannot have general peace for the asking nor by the arrangements of a peace conference. It cannot be pieced together out of individual understandings between powerful states.

In his speech on the $4^{\text {th }}$ of July, I9I8, he repeats:

The settlement of every question, whether of territory, of sovereignty, of economic arrangement, or of political relationship, upon the basis of the free acceptance of that settlement by the people immediately concerned, and not upon the basis of the material interest or advantage of any other nation or people which may desire a different settlement for the sake of its own exterior influence or mastery.

Similar professions have been made by the leading statesmen of Britain, France, and Italy. Thus Winston Churchill, as First Lord of the Admiralty, declared on September II, I9I4: "Let us, whatever we do, fight for and work towards great and sound principles for the European system. And the first of those principles . . . is the principle of nationality. . .".15 Sir Edward Grey stated on March 22, I9I5, while he was still Minister of Foreign Affairs, that "we wish the nations of Europe to be free to live their own independent lives, working out their own forms of government for themselves, and their own national developments, whether they be great nations or small states, in full liberty." 16 On September 26, I9I7, Asquith emphasized that the final settlement must not ignore "the principles of right" and set at defiance "the historic traditions, aspirations, and liberties of the peoples affected." ${ }^{17}$ Lloyd George

${ }^{15}$ Comments by the German Delegation on the Conditions of Peace, First part, II, 5.

16 The New York Times Current History, vol. ii, p. 283.

17 Ibid., vol. vii, part I, p. 292. 
declared on January 5, I9IS, that "the days of the Treaty of Vienna are long past, . . government with the consent of the governed must be the basis of any territorial settlement. ..."18 The same principles were voiced by the Italian Prime Minister, Vittorio Orlando, on Decenber I2, I9I $7,^{18}$ and for France by Stephen Pichon, then Minister of Foreign Affairs, on December 28, I9I7, and on January I I, I 9 I $8 .{ }^{20}$

The statesmen of the Central Powers have been much less specific in their professions of acceptance of the new principle, and where they are explicit they follow with a qualification. In the German reply to the Pope's peace proposal, "the Imperial Government greets with special sympathy the leading idea of the peace appeal wherein his Holiness clearly expresses the conviction that in future the material power of arms must be superseded by the moral power of right." "21 The Austrian version states that "with deep-rooted conviction we agree to the leading idea ... that the future arrangement of the world must be based on the elimination of armed forces and on the moral force of right and on the rule of international justice and legality." 22 In their peace proposals of December, I9I7, they profess that "forcible annexation of territories seized during the war does not enter into the intentions of the allied [Teutonic] powers" and that "in accordance with the declaration of statesmen of the Quadruple Alliance, the protection of the rights of minorities constitutes an essential component part of the constitutional rights of peoples to self-determination, indicated by a constitution. The allied [Teutonic] Governments also grant validity to this principle everywhere, in so far as it is practicably realizable."23 By the signing of the Armistice Germany has unconditionally accepted President Wilson's Fourteen Points and his later

18 Ibid., vol. vii, part 2, pp. $266-271$.

19 Ibid., vol. vii, part 2, p. 272.

$20 \mathrm{Ibid}$., vol. vii, part 2, pp. 2ro-212; see also above, p. 177 , note 15.

21 Ibid., vol. vii, part I, p. 285.

22 Ibid., vol. vii, part I, p. 286.

23 Ibid., vol. vii, part 2, p. 263. 
four point summarization of February II, I9I8. The reply of the Republican German Government to the first Peace Treaty draft states that "in this war, a new fundamental law has arisen which the statesmen of all belligerent peoples have again and again acknowledged to be their aim : the right of self-determination. To make it possible for all nations to put this privilege into practice was intended to be one achievement of the war." ${ }^{24}$ In the case of the proposed return of Northern Schleswig, the German reply reminds the Allies that the German Government had, independent of outside pressure, approached Denmark in the question of a rectification of their boundary. The reference reads:

Although the German Government has declared its readiness to meet the Danish wishes for a new frontier corresponding to the principle of nationality, using the peace negotiations as a roundabout means of establishing it, it cannot refrain from referring to the fact that the Schleswig question is not expressly mentioned in President Wilson's points. If Germany agrees to a plebiscite in Schleswig, she does this because she recognizes the right of self-determination of the peoples. ${ }^{25}$

What then has happened since i 867 or I 898 ? Have the Hague Conferences brought about such a fundamental change in the sentiment of the representatives of the great nations who are the makers of international law? Hardly! At the Hague the subject was not even officially discussed. Have national and international peace and pacifist societies prepared the ground? Among individuals, possibly, but not among governments!

It must be left to the future historian and student of international law to inquire into the manifold and innermost reasons for their present change of front. The present observer can only record the facts as presented.

President Wilson's attitude and proposed method of settlement of territorial changes were, of course, those of the official representative of the United States. While they had to be accepted by friend and foe, they did, after all, lack that final stamp of the country's approval which the

24 First part, II, 5 .

25 Second part, II, 8. 
Constitution vests in the Senate through the treaty clause. But aside from this, the President's proposed course may, from all appearances, be interpreted as the attempt to direct the American state policy with a perspective, wider and broader than that of the past.

After the ratification of the treaty of peace between Peru and Chile in March, I884, which deprived Peru of her rich nitrate and guano provinces, the Congress of Venezuela thus expressed the then prevalent sentiment of condemnation of Chile's action: "We solemnly protest against the iniquitous and scandalous usurpation of which Peru and Bolivia are the victims, in spite of their heroism, and we beseech the God of nations to look favorably on the prompt restoration of lawful sovereignty for peace and concord among the sons of America.",26

At the First International American Conference held in Washington in 1890 , the following resolutions were adopted, Chile alone not voting:

First: That the principle of conquest shall not, during the continuance of the treaty of arbitration, be recognized as admissable under American public law.

Second: That all cessions of territory made during the continuance of the treaty of arbitration shall be void if made under threats of war in the presence of an armed force.

Third: Any nation from which such cession shall be exacted may demand that the validity of the cessions so made shall be submitted to arbitration.

Fourth: Any renunciation of the right to arbitration, made under the conditions named in the second section, shall be null and void.27

Thus among the states of the American continent title by conquest was no longer to be acknowledged, and the way opened for the adoption of the principle that the wishes of the inhabitants of the territory ceded should be consulted.

It thus seems that President Wilson, in framing his Fourteen Points on the principle of no conquests and popular consent for all territorial settlements, was in reality voicing not only his own political conviction but the summary and

${ }^{26}$ C. R. Markham, History of Peru, Chicago, I902, p. 425.

$2 \pi$ International American Conference, Washington, I880-1800, Reports of Committees and Discussions thereon, vol. ii, pp. II47-I I48. 
quintessence of the contemporary political faith of the larger America.

But as Gladstone's suggestion of a plebiscite in AlsaceLorraine could not command the assent of the neutral powers in $187 \mathrm{I}$, so has President Wilson's sponsorship of the principle of self-determination not been able to establish this dogma as a valid international rule without the universal consent of the rest of the civilized world. No more could the assent of the Pan American nations to this principle, and their adoption of it into American public law, enforce its incorporation into international law without the free consent of all or nearly all other nations. For if with Lawrence "we mean by a source of law that which gives it authority and binding force, then there is but one source of the law of nations, and that is the consent of nations," and "no rule can have authority as International Law unless it has received the express or tacit acceptance of the great majority of civilized States." 28

Prior to the World War such consent had not been formally given. But, to quote Lawrence, "unless all or nearly all civilized powers have signed a document which lays down the rule, the best evidence of their consent is practice." ${ }^{29}$ So far pre-World War history has to show hardly a single genuine case of cession by conquest where the consent of the people of the territory ceded was solicited by a referendum. Even in the case of the acquisition of Rome by the Kingdom of Italy in 1870 the plebiscite or referendum followed the acquisition by conquest and was held while the city was occupied by the conquerors, and there can be no doubt that if the result of the referendum had been unfavorable the wishes of the people would have simply been ignored. $^{30}$ Technically, of course, this case constitutes a precedent for a transfer of territory by title of conquest

${ }^{28}$ Lawrence, A Handbook of International Law, London, 9th ed., 19I5, p. 29.

${ }^{29}$ Ibid., p. 34.

${ }^{30}$ See Dupanloup's charges that the favorable result of the plebiscite was secured by fraudulent votes, above, pp. 94-95. 
where the plebiscite has been employed, and it must be cited as such. However, within the limits of this study we include territorial changes by title other than conquest on the basis of the undeniable fact that the desire of a people for the expression of its wishes in the matter of a change of sovereignty is or may be just as strong when the transfer is affected by treaty of peaceful cession as when their territory is ceded after conquest. We thus enlarge the scope of precedents by the admission of all those cases where the principle of self-determination has been applied in the cession or transfer of territory in whatever peaceful form. Still, all these precedents in their sum total do not establish the principle in question as international law unless sucl a practice becomes universal or so general that, by universal or at least general consent of the Powers which have established them, it is recognized as sufficiently forceful and convincing to influence new decisions plainly and explicitly on the strength of these precedents of the past.

The same forces which were instrumental in creating these carlier cases are, of course, constantly at work in the attempt to gain for these precedents international recognition and to secure final acceptance of the principle involved as universal or international law. These forces are: the impersonal opinion of the masses; the personal view of statesmen, philosophers and writers on international law, who crystallize public opinion and deduce the growing norms of international law from the accumulation of precedents; and the force of analogy of constitutional and municipal law as exponents of the public will. There can be no denial of the fact that constitutional and municipal law have come to recognize almost universally the principle of self-determination in all matters which lie within their sphere. In substantiation of this statement, one need point out only that constitutional and representative government and legislation by representative bodies elected by popular vote are almost universal. Nor can we disclaim the influence, by analogy or otherwise, of constitutional and municipal law on the 
shaping of principles and rules for decisions in matters affecting international relations, whether we hold that international law is law in the same sense that national law is ${ }^{31}$ and that it constitutes an integral part of the municipal law of, for instance, Great Britain, the United States, and the new German Republic, ${ }^{32}$ or whether we follow those who believe that, where and when English, American, and German courts adopt and apply principles of international law, they are so applied and enforced not as international but as municipal law. ${ }^{33}$ For, where, in the application of the principles of international law by municipal courts, these principles conflict to the extent that they cannot be reconciled with the accepted norms of common or national law, the courts decide according to the law of the land. ${ }^{34}$ In such cases it is the business of the State or the Crown to allay the differences which such a decision may cause in the international relations with other states. It is in the decisions of courts in such cases of conflict between common or expressed municipal law and international practice with the possible consequence of international negotiations that we may find a field for a slow but sure encroachment of principles of constitutional and municipal law upon the realm of rules governing the conduct of nations.

However, from the point of view of constitutional law there is an obstacle to the universal acceptance of the plebiscite as a means of expression of a popular desire for selfdetermination. The constitutional legislation of revolutionary France recognized the plebiscite in the case of all revolutionary movements of whatever country or fragment of a country as a legitimate means of secession from their

31 J. B. Scott, The Legal Nature of International Law, in The American Journal of International Law, October, 1907, pp. 83I-866. 32 Article 4 of the Constitution of the German Republic reads: "The universally recognized principles of the laws of nations are accepted as binding elements of the laws of the German Nation."

${ }^{33}$ Willoughby, The Legal Nature of International Law, in The American Journal of International Law, April, I908, pp. 357-365.

3* C. M. Picciotto, The Relation of International Law to the Law of England and of the United States of America, New York, I9I5, especially p. 26. 
old allegiance and of accession to France. Put the same republican France decreed the death sentence for anyone speaking of and considering the cession of French soil to a foreign power. ${ }^{35}$ Even the French protest against the enforced cession of Alsace-Lorraine in I87I was based, not on the rights of the poptlation of the territories concerned, but on the violation of French territory.36 No government could expect to survive which by its fundamental law would consent in principle to a cession of territory by a vote of the secessionists and propose the way and means for such cession by its recognition of the plebiscite, as long as such consent might serve as an invitation to land-hungry neighbors to take advantage of the situation thus created in order to establish in the former state, through intrigue, plotting, and intervention, a sentiment and disaffection with a view to their own territorial aggrandizement.

The new German Constitution of August 13, 1919, states in Article 2: "The territory of the nation consists of the territories of the German States. Other territories may be taken into the Government by national law, when their inhabitants, by vote of self-determination, express such a desirc." Territorial adjustment of state boundaries within the confines of the Republic, on the basis of popular referenda, are provided for in Article 18. But the provision for the change of frontiers of the Republic involving cession of German territory to a foreign Power does not mention the plebiscite. Article 78 reads in part: "Agreements with foreign States regarding change of national boundaries may be concluded by the nation on consent of the State involved. Alterations of the boundaries may occur only on the basis of a Government law [a federal law], except in cases where mere correction of the boundaries of uninhabited districts is in question."

In the second part of the German counter proposals to

${ }^{85}$ See above, p. 79, note 105 . On Sept. 25, 1792, the Convention nationale decreed that "La République française est une et indivisible" (Arch. parl., ser. I, vol. lii, p. I43).

se See above, p. 53, note 78 . 
the Treaty, Germany asserts that: "No territory shall be separated from Germany where national adherence has been proved to be indisputable by harmonious union with the German State for centuries, or whose population has not declared its consent to such a separation." ${ }^{37}$ This admission of the plebiscite as a means to determine popular consent to the separation of German territory rests, however, on a negative premise. It is not said that German territory may be ceded upon the recording of a popular desire to that effect, but rather, that "no territory shall be separated from Germany... whose population has not declared its consent to such a separation." Furthermore, even this concession is not made voluntarily. The separations here contemplated are those exacted by the Peace Treaty, and Germany's consent to these territorial cessions, no matter under what form, has been enforced. Lastly, the paragraph of the German reply claims to be no more than an expression of a policy which Germany desires to have applied to the territorial settlements as provided in the Treaty; as such it has no legal validity.

In the United States the constitutional right to annex foreign territory has been, at various times, and by various writers, derived from the following sources:

I. The power to admit new states into the Union.

2. The power to declare and carry on war.

3. The power to make treaties.

4. The power, as a Sovereign State, to acquire territory by discovery and occupation or by any other methods recognized as proper by international usage. ${ }^{38}$

Actual annexation of territory by the United States has taken place "in three different ways: (I) by statute, (2) by treaty, and (3) by joint resolution." 39

The consent of the inhabitants of the territories annexed need not and has not been asked. The act of annexation derives its legal force "from the body which enacts it, and

37 Second part, II, I, A.

ss Willoughby, The Constitutional Law of the United States, New York, I910, vol. i, pp. 325-34I.

39 Ibid., vol. i, pp. 344-347. 
it would be an error to hold its legal force necessarily dependent upon a consent obtained from some other source. ..."There is, according to the same authority, no reason why Congress could not make an annexation dependent upon the consent of the population of the territory to be annexed, "but this is not a matter of legal necessity." ${ }^{0}$ "Nor is there any principle of public law, or general precedent from our own practice that requires the consent of the population of an annexed territory to be obtained. In none of the instances, except that of Texas, has the United States deemed this consent necessary." ${ }^{11}$

Texas was annexed by Joint Resolution, annexation by treaty having been unsuccessful owing to the failure to secure a two-thirds vote in the Senate. The resolution states that "Congress duth consent that the territory properly included within and belonging to the Republic of Texas may be rected into a new State to be called the State of Texas with a republican form of government to be adopted by the people of said republic, by deputies in convention assembled, with the consent of the existing government, in order that the same may be admitted as one of the states of the Union." 42 The consent here asked seems to have been more like the fulfilment of a condition requisite to admission as a state than a declaration of a willingness to be annexed, for "upon Texas taking the action called for by this clause, Congress later by Joint Resolution declared Texas one of the States of the American Union." 43

While there have been several boundary settlements in which territory formerly held by the United States has been surrendered to foreign powers, the title to these stretches of land as United States territory must be held to have been faulty and it must be assumed that the surrender was made on that ground. "There has been no instance in which territory, indisputably belonging to the United States, has

40 Ibici., vol. i, p. 347.

41 Ibid., vol. i, p. 348.

42 Ibid., vol. i, pp. 344-345.

43 Ibid., vol. i, p. 345 . 
been alienated to another power." ${ }_{44}$ It is generally held that the right to alienate United States territory, if the occasion should arise, is inherent in the treaty making power. This right of alienation under the treaty making power has been questioned by various obiter statements of the Supreme Court. For example, in De Geofroy v. Riggs, Justice Field asserted that the United States could not by treaty cede the territory of any State without the latter's consent. ${ }^{45}$

Reference has been made to the adjustment of the northeastern boundary dispute in 1842 with Great Britain "in which the United States, before coming into an agreement with Great Britain, obtained the cooperation and concurrence of Maine and Massachusetts." ${ }_{46}$ However, from the correspondence of Webster, then Secretary of State, to the Governor of Maine "it does not appear... that he considered this a constitutional necessity, but rather that it was expedient from a political standpoint that the opinion of these two States should be considered." 4 z

In the case of Downes v. Bidwell, Justice White argued that the United States could not alienate under the treaty power any of its incorporated territory either by sale or trade. However, he admitted that "from the exigency of a calamitous war or the necessity of a settlement of boundaries, it may be that citizens of the United States may be expatriated by the action of the treaty-making power, impliedly or expressly ratified by Congress." ${ }^{48}$

The American policy in the matter of alienation is well expressed in the words of Kent in his Commentaries: "The better opinion would seem to be, that such a power of cession of the territory of a State without its consent does reside exclusively in the treaty-making powers . . . yet sound

44 Ibid., vol. i, pp. 507-508.

45 Ibid., vol. i, p. 508.

46 Ibid., vol. i, pp. 508-509.

47 Ibid., vol. $i$, p. 500 . In this letter Webster wrote: "In the present position of affairs, I suppose it will not be prudent to stir in the direction of a compromise without the consent of Maine."

48 A more detailed account of the United States Supreme Court statements referred to is found, ibid., vol. $i$, pp. 508-5i3. 
discretion would forbid the exercise of it without the consent of the local governments who are interested, except in cases of great necessity, in which the consent might be presumed." 49

$A$ recent case of the alienation of British territory is the cession of Heligoland to Germany in I890. On June 24, the First Lord of the Treasury, IV. H. Smith, was asked in the House of Commons by Mr. Summers "whether he will undertake that the proposed Anglo-German Agreement shall not be signed by the British Plenipotentiary until Parliament has had an opportunity of expressing its opinion on the bill for the cession of Heligoland; and also whether the proposed... Agreement will contain a clause providing that the portion of the Agreement which relates to the ce:sion of Heligoland shall not take effect until it has been ratified by the passing into law by the British Parliament of a Bill authorizing the cession?" To this Mr. Smith answered that "no such clause is necessary, for the Agreement will only provide that a Bill shall be introduced to enable Her Majesty to make a cession." ${ }_{50}$

The British Government's attitude in the question of popular consent as a pre-requisite to the validity of the transfer is found in the statement made in the House of Lords by the Prime Minister and Secretary of State for Foreign Affairs, The Marquis of Salisbury, on June 19, I890: "The plébiscite is not among the traditions of the country. We have not taken a plébiscite, and I see no necessity for doing so. . . ."

Returning to the consideration of the forces acting in favor of the international sanction of the plebiscite as the mode of expression of popular consent, it is to be observed that the negative opinions of Hall, Hershey, Oppenheim and others, are opposed by some writers. Thus Hershey cites "among the few advocates of the plebiscite in the

49 Quoted from Willoughby, vol. i, p. 5II.

50 Hansard's Parliamentary Debates, vol. 345, col. 1796.

51 Ibid., vol. 345 , col. I3I I. 
case of cession," Funck-Brentano, Sorel, Rouard de Card, and Rotteck. ${ }^{52}$

In opposition to the opinion of Seward, Sherman, and the Duke of Argyll, we have the views of Gladstone, Wilson, Lloyd George, Pichon, Orlando, and von Hertling. While not agreeing in the details of practical application, they all seem to be in harmony as far at least as the principle itself is concerned. Lloyd George goes even so far as to demand self-determination for the German colonies. In his address of January 5, I9I8, before the Trade Union Conference, he said :

The natives live in their various tribal organizations under chiefs and councils who are competent to consult and speak for their tribes and members and thus to represent their wishes and interests in regard to their disposal. The general principle of national selfdetermination is, therefore, as applicable in their case as in those of the occupied European territories. ${ }^{53}$

In the chapter on "Treaties with uncivilized tribes," Westlake reminds us that European powers, when they set out to acquire territory of uncivilized peoples, first proceed "to conclude treaties with such chiefs or other authorities as they can discover," and he thinks that they do so "very properly, for no men are so savage as to be incapable of coming to some understanding with other men, and whenever contact has been established between men, some understanding, however incomplete it may be, is a better basis for their mutual relations than force." Granting that "natives in the rudimentary condition supposed take no rights under international law," and that "no document in which such natives are made to cede their sovereignty can be exhibited as an international title," he adds that "an arrangement with them, giving evidence that they have been treated with humanity and consideration, may be valuable as obviating possible objections to what would otherwise be a good international title to sovereignty." ${ }_{54}$

52 Hershey, p. I83; see also above, p. I7I, note I.

53 New York Times Current History, vol. vii, pt. 2, p. 270.

$54 \mathrm{~J}$. Westlake, Collected Papers . . on Public International Law, Cambridge, 1914, p. 146. 
When uncivilized peoples are by our international jurists and by the statesmen of colonizing powers considered as deserving of lumane and considerate treatment, when it is held proper to make treatics with the chiefs and leaders of uncivilized races, when an understanding completed with them seems a better basis for mutual relations than sheer force, when all this is conceled, then the question seems to be pertinent why civilized peoples, whose territories are to be transferred from one state to another, should be shown less consideration than that accorded to the Bushmen or Kaffirs? Considered from a purely humane and moral point of view the logic of the question seems to be unassailable. However, international law was not originally humane or moral. Hunanitarian and moral principles were first introduced into the rules of making and conducting war and concluding peace under the influence of the mediaeval Christian writers and in a systematic attempt by Hugo Grotius to mitigate the prevailing cruelty and selfishness in both war and peace. ${ }^{55}$ But until now there has come into existence no international agreement on the nature and extent of the basic laws of humanity and ethics to apply in the relations of states.

By universal or general international agreement existing rules for the conduct of nations may be altered to suit new situations. However, where the required minimum of general consent is not ascertainable and the opposition of the dissenting states is not overcome by force of arms, a pending case must be and is decided on the basis of past practice. Under these conditions international jurists and statesmen can be of real and effective service to humanity and morals only where and when international law supplies no rule or precedent for a concrete case, and where, by deciding a new issue in accordance with recognized principles of right and wrong, they introduce into international practice a precedent established not on an unmoral, but on a moral basis.

${ }^{55}$ Dunning, A History of Political Theories, From Luther to Montesquieu, p. I32 ff. 
But as soon as we demand a moral standard for international decisions and consequently for international law, we practically revive the difficulty which confronted the adherents of natural law as the source of the law of nations. It is the difficulty of evolving that moral standard which will find approval and acceptance by all concerned. We would have to satisfy a minimalist's and a maximalist's and even a crank's opinion. This is, no doubt, one of the reasons why up to the present day no workable code of international ethics has been evolved.

Oppenheim discusses this phase of the issue in his interpretation of the task and method of the Science of International Law. "The science of international law," he wrote in 1908, "is . . a means to certain ends outside itself. And these ends are the same as those for which international law has grown up and is still growing-primarily, peace among the nations and the governance of their intercourse by what makes for order and is right and just. . .." According to Oppenheim one of the most important tasks of the science is criticism of the prevailing rules of international law, and, therefore, he says, "the questions which must be answered are: Is a certain rule really just and adequate, or is it antiquated, so that it ought to be restricted, abolished, or replaced"? But he gives the following warning :

If even so much importance is attributed to the criticism of the present condition of international law, it must never be forgotten that his law is like everything else conditioned by the milieu of the age. ... If anything else is dependent upon gradual historical developement, it is that delicate body of rules which is called international law. The dreamer and the schemer build their castles in the air without regard to the real facts of life. The armchair politician and the moralist lay down the law without regard to the possibilities of the age. The preacher and the philosopher defend postulates which are beyond realization in practice. But the international jurist must not walk in the clouds; he must remain on the ground of what is realizable and tangible. It is better for international law to remain stationary than to fall in the hands of the impetuous and hotheaded reformer. He who knows how difficult it is to unite all the members of the family of nations for the purpose 
of the shortest step forward will not lend his ear and his arm to chimerical proposals. ${ }^{56}$

What then is the "milicu of the age" to-day? Or, rather, what was the "milien of the age" when the representatives of the Allied and Associated Powers met in conference at Paris in IgI 8 to frame the treaties of peace? Was it not the almost universally expressed tendency towards recognition for the principle of self-determination of nationalities and races? Had not practically all the members of the family of nations pledged themselves to the acceptance of the principle?

The Treaty of Versailles provides for a number of territorial cessions by Germany to her neighboring states, all entailing the loss of German nationality. Some of these cessions are demanded on the principle of national self-determination and plebiscites in some form or other are stipulated; some are outright cessions without the consultation of the populations thus transferred. In the case of the cessions of this last type we must again distinguish between a first class where the Allied and Associated Powers assume and assert the indisputable non-German character of the population transferred, and a second class where the same Powers frankly admit the German contention that the territories thus to be ceded are purely or largely German in language and racial characteristics. The first class may still be assigned to the category of territorial changes effected on the principle of national consent. This can, however, not be said of the second class. Neutral Moresnet is ceded to Belgium without special justification. Prussian Moresnet goes to Belgium " in partial compensation for the destruction of Belgian forests," that is, on economic and reparatory grounds. Western Prussia must be ceded to Poland in order that the Allies be enabled to keep their war pledge guaranteeing the reestablishment of Poland. We have here the coincidence of historical reasons and of

56 Oppenheim, The Science of International Law: Its Tasks and Method, in The American Journal of International Law, April, Igo8, pp. 3I4, 3I8. 
motives of an opportunistic policy. The same must be said of the enforced surrender by Germany of the City of Danzig, though here the economic needs of Poland for Danzig as an outlet to the sea are given as an added reason. The City and district of Memel are to be ceded by Germany, without consultation of the admittedly large majority of Germans in Memel, in order to secure for Lithuania an exit to the water, again on the grounds of economic arrangements. Germany is forced to renounce, in favor of CzechoSlovakia, all rights and title over part of the Kreis Leobschütz "in case after the determination of the frontier between Germany and Poland the said part of the Kreis should become isolated from Germany." The population, though German, is not to be consulted in the matter of transfer. The principle on which this transfer is based is without question that of opportunism.

The Treaty of Versailles has borne out Oppenheim's statement that "the necessities of international policy may now and then allow or even demand such a plebiscite but in most cases they will not allow it." ${ }^{\prime 27}$

This verdict receives substantiation from the Austrian Treaty which refuses German-Austria the right to determine her political status by making her inclusion in the German Republic subject to the consent of the League of Nations which consent is, however, for the time being withheld. The same Treaty forces Austria to cede to Italy Southern Tyrol as a strategic frontier rectification promised Italy by the Allied Governments in the secret Treaty securing and conditioning İtaly's entrance into the war." ${ }^{8} 8$

Thus the principal Allied and Associated Powers in the treaties in question have on the one hand granted and demanded the application of the plebiscite in some cases of territorial settlements while in many other instances they have refused the holding of a plebiscite even where such is demanded for the territories affected by the state which is

57 See above, p. I72, note 4.

58 New York Times Current History, vol. vii, part 2, pp. 494-497. 
forced to surrender them. While the term conquest has heen persistently avoided in the cases of enforced cession without recourse to the principle of self-determination, those annexations by the respective Allied Powers differ neither in the method of nor in the motive for acquisition from the territorial aggrandizenents of the past.

The conclusion is inevitable that the Peace Treaties ending the World War have so far not established a universal or even general practice of a settlement of territorial questions on the basis of the principle of self-determination by the plebiscite. Nor have they eliminated acquisitions of territory on the implied principle if not the expressed term of conquest.

Assuming that the ratification of the treaties by the constitutional agencies of the countries involved does establish as international law the norms on which the treaty provisions are built, we come to the inevitable conclusion that these treaties have given international legal validity to a practice which by the will of the one of two contending parties, enforced upon the other, establishes the use of the plebiscite in some territorial cessions and prohibits the expression of popular consent or disapproval in others.

But even this assumption rests on premises of a problematic nature. The present treaties, though ratified, are subject to amendment and replacement by other agreements which may offer a different solution of the territorial questions involved, changing or reversing some of their present stipulations. In fact, Article i9 of the League Covenant as part of the Treaty of Versailles provides that the Assembly of the League "may from time to time advise the reconsideration by the Members of the League of treaties which have become inapplicable and the consideration of international conditions whose continuance might endanger the peace of the world."

Another consideration against the preceding assumption is the fact that the United States Senate has twice voted 
against the ratification of the Treaty of Versailles. ${ }^{59}$ Whether a United States Senate will later ratify the Treaty or not, the two earlier refusals will play an important part in future discussions and opinions concerning the international legal validity of the principles embodied in the Treaty. What Oppenheim stated for the time prior to the World War still remains true: "It is doubtful whether the law of nations will ever make it a condition of every cession that it must be ratified by a plebiscite."60

\footnotetext{
${ }^{59}$ Nov. 19, 1919; Mar. 19, 1920.
}

60 See above, p. I72, note 4 


\section{CHAPTER IX}

\section{Conclusion}

In the last analysis every government, from republic to absolute monarchy should depend for its existence upon the principle of popular consent. The ease or difficulty with which an existing form of government may be changed, or its acts controlled, are proportionate to the facilities or restrictions governing the manifestation of popular consent or disapproval.

Our earliest knowledge of the Germanic tribes testifies to the existence of a system which provides for the granting or withholding of poptular consent in all important matters affecting the life and welfare of the tribe: regular or specially called gatherings in which all freemen, their arms in hand, partake in the decision of all those affairs which are discussed by their chiefs and "such others as are conspicuous for age, birth, military renown, or eloquence." Their leaders "gain attention rather from their ability to persuade, than their authority to command." As our authority, Tacitus, relates: "If a proposal displeases, the assembly reject it by an inarticulate murmur; if it prove agreeable, they clash their javelins." $\quad$ These manifestations of the popular will were a matter of custom; they were not the result of rights acquired by struggle and revolution and briefed by law. With the catastrophic upheavals of the period of the migrations and the subsequent development of the feudal system, these popular gatherings of the German tribes finally ceased except with the remmants of the Burgundi and Alemanni in their new homes in the mountains of Helvetia. The modern Western peoples sprung from the racial fragments of the old Germanic tribes have only after many centuries of po-

1 See above, p. 19. 
litical struggle and rebellion succeeded in the reestablishment of representative government based upon the system of their forebears.

The Greeks of Homeric times, and probably all human groups living under the same social and political conditions, have had those tribal or communal gatherings for the sake of a mutual discussion and decision in matters vital to their physical and political existence. But owing to the steady growth of the population of the tribe or of the tribes within the group, sooner or later the chiefs and leaders nearly everywhere succeeded in the more or less effectual elimination of the great mass of the people from the councils, or even in the suppression of all public consideration of the affairs of the group.

It is in the resentment of the masses thus excluded, and in the attempt to regain their old position of influence in the decisions affecting their own welfare as well as that of their kings and ruling caste, that the institution was born which has been named the plebiscite.

In the Republic of Rome the plebs began to resent the dictation of the ruling Patricians. The plebeian members of the Roman commonwealth followed the natural human instinct to gather for the discussion of their grievances and to find ways and means to redress them. Resolutions were passed accordingly, but resolutions are ineffective unless they be given legal value or are otherwise enforced. To receive legal standing these resolutions had to receive the sanction of the Patricians in the Roman Senate. To gain this sanction the plcbs was compelled to pass other resolutions, deciding on the refusal to bear arms in the wars declared by the Patricians, to emigrate from the city, etc. Thus the Roman Senate was forced to yield. The resolutions and decisions passed in the plebeian assemblies received the sanction of the patres and became law not only for the plebeians alone but for all Romans. The pendulum swinging from one extreme to the other, all Rome was for a time subject to the law of the plebs. 
The conception of popular consent or of popular government of the Germanic and Greek tribal assemblies was that of mutual participation, through discussion and decision by all classes of freemen, in all affairs vital to the group. Popular consent and government as established by the Roman plebs constituted rule over all classses by one, the plebs.

The Germanic and Greek systems provided for the rule by the majority of all freemen, while the Roman plebiscitum merely replaced the class rule of the patricians, as far as such existed through the exercise of the auctoritas patrum, by the class rule of the plebeians. The modern system of popular voting passing under the old Roman name of the plebiscite does not exhibit the feature of class limitation as an essential characteristic. There have been restrictions of the vote and of the voters in many cases where the plebiscite has been applied, but these restrictions have been as a rule not openly admitted; they have rather been surreptitiously planned and effected. From the point of view of the present the significant aspect of the rule of the Roman plebeians through their plebiscita is, then, not that of the prevailing of the plebs as a majority-though the plebs was most likely numerically stronger than the patricians-but that of the temporarily successful assertion of a class which deemed itself oppressed.

It is in this last respect that the plebiscite has functioned in international relations. For the principle and foundation of the plebiscite, as applied in territorial settlements, is to give to suppressed minorities a way of voicing their objection to the rule of the dominant political unit to which they are held against their will and to gain through the objections thus voiced their freedom in the form of independence or of another allegiance. This being the definition of the plebiscite employed in the settlements of a territorial character, its justification stands or falls with its success or failure to produce the results promised or expected. 
The plebiscite in the determination of sovereignty gives voice to a suppressed minority, and, through the voicing of the will of this minority, gains for it political separation from its superior. Whence does our modern demand for a plebiscite in a supposedly suppressed minority arise? From our conviction, first, that the minority in question is suppressed, second, that this minority wishes to be free of such suppression, and that all, or nearly all, of that minority are in agreement on this point. How does such a conviction come to us? Through the utterances and the actions of this minority! But if the utterances and the actions of this minority so clearly establish our conviction that all or nearly all its individuals are suppressed and desire delivery from this state of suppression, why demand a plebiscite to establish what is already apparent? Where this conviction is clear, the plebiscite is evidently superfluous. ${ }^{2}$, No plebiscites were needed or demanded by the Allied and Associated Powers to establish the fact that the suppressed minorities, Czecho-Slovakia, Jugo-Slavia, and Poland, desired political independence from Austria-Hungary, Russia, and Germany. The Peace of Versailles provides for two voting zones in the northern part of Schleswig. There must have been a reason for this, a conviction that this twozone arrangement would suit the requirement of the situation better than would any other arrangement. This conviction had been gained without the application of any plebiscites. In fact, the plebiscite was to be and was held under the conditions thus established upon the basis of facts already known. The subsequent plebiscites proved the ar-

2 The same conclusion is reached by Padelletti, though his argumentation proceeds from somewhat different premises. Padelletti holds that "the will of the people is manifested ... always in the events themselves: the plebiscite is always only an expression of this will." Speaking of the plebiscites in Savoy and in Nice at the occasion of the transfer of these Italian provinces to France in I860, he claims that "everybody knew the truth of this observation and best of all those who were ceded themselves," namely that the plebiscite also in this instance was "nothing but the superfluous ratification of a fait accompli" (G. Padelletti, L'Alsace et la Lorraine, et le droit des gens, in Revue de droit international et de législation comparée, I 87 I, vol. iii, pp. 488-489). See also above, p. 96. 
rangement to have been correct. In the northern section a vote of practically 3 to $I$ in favor of Denmark was returned. $^{3}$ In the southern zone the result showed the same proportion in favor of Germany.* Prior to the signing of the treaty, Germany had conceded to Denmark the right to the Danish sections of Schleswig. ${ }^{5}$ Denmark had objected to the original, too liberal, line of demarkation proposed by the Allies. Denmark wanted none of the German sections. ${ }^{6}$ Germany's reply to the first treaty draft suggested one zone to include all communes where the Danish language was spoken by at least fifty per cent of the population. ${ }^{7}$ There were in these suggestions and proposals clearly the essentials of a settlement between the parties concerned on the basis of the will of the people involved. The essential element was the willingness on the part of Germany to acknowledge the Danish sentiment of Northern Schleswig and to relinquish that territory on the grounds of this acknowledged sentiment-and Denmark's honest admission that the line as originally proposed by the Allies went beyond her legitimate claims based on popular consent. The one question which was still waiting for a decision between the three parties to the transaction was whether popular consent would be construed as meaning a simple majority, or two-thirds, or even more of the community vote. It was easily conceivable that in a few communities a vote would be required to establish the existence or nonexistence of the fixed majority, decided upon in advance as a basis for the transfer. Still in these cases the plebiscite would serve not to free a suppressed minority, but merely to establish majority rule as it does in the issues of political life in general. ${ }^{8}$ In the case of the voting in the two Schleswig zones, the decision with regard to the future

\footnotetext{
3 New York Times Current History, vol. xi, part 2, pp. 424-426.

4 Ibid., vol. xii, pp. 22-24.

5 See above, p. I 39 .

'See notes, 2-3. See also the Allies' reply to the German counter proposals, cited above, p. 139 .

i See abrove. p. I39.

${ }^{8}$ See above, p. I6I; below, p. 201.
} 
allegiance of the voters was reached on a simple majority basis. The same has apparently been true in all instances of territorial transfers where the plebiscite has been employed.

The simple majority vote has been found practicable as an expedient method of settlement in many internal affairs of government, such as the election of representatives, executive officers, the decision on proposed ordinances and legislation. As thus employed it offers a quick decision, but it also permits a more or less speedy reversal of its verdict. In each contest the party defeated yields to the majority only temporarily, that is, until it in turn is able to cast a majority vote. This is not so in the case of territorial transfers which are considered permanent and not reversible. Here a bare majority can force a nearly equal number into a lasting undesired allegiance. By parity of reason this new subjected minority should be permitted to gather and augment its strength for a new voting contest in which it in turn may master the deciding majority, or it should, by the consistent application of the doctrine of selfdetermination, be allowed to choose its own allegiance as a separate group.

In other words, where the separatist sentiment of any minority group demanding liberation from an undesirable allegiance is not substantially unanimous, the plebiscite does not and cannot achieve its full allotted function. We have illustrations of this in the transfers enforced by the Treaty of Versailles of German territory to CzechoSlovakia and Poland, coupled with the provision that the cultural interests of the German populations under their enforced foreign allegiance shall be protected.

But even in internal affairs political practice sometimes requires a much larger, in some cases even a three-fourths majority vote in the decision of issues involving matters of great importance or of a lasting character such as the amendment or the change of a constitution. By force of equity one should thus demand more than a bare majority 
for the most inportant decision a group may be forced to make-that of choice of sovereignty. The exact proportion decided upon in each case must depend on the various motives prompting the demand for a change and whatever other factors may justly enter into the consideration of all the parties concerned.

The essential part in territorial adjustments is not the plebiscite but the agreement on that proportion of the vote which will effect a solution productive of the lasting peace of the population subject to the change proposed.

The plebiscite can render effective service only when and where such binding agreements, free from all force, have been reached in advance by the parties involved to the effect that a majority of a fixed and agreed proportion shall prevail, and where the plebiscite is employed solely to establish which side of the issue involved can muster this majority and where the resulting minority is assured a fair degree of local autonomy and the enjoyment of its own language and religion.

But when agreements of this nature become universally possible in the case of territorial settlement and in the determination of sovereignty, the necessity of liberating suppressed minorities by way of plebiscites will no longer exist. Conquest will no longer seem profitable and will actually cease because the victor will in advance bind himeslf to relinquish his prey in case the result of a vote falls below the majority agreed upon as essential to the annexation.

However, a state ready to grant, without coercion of whatever kind, such a degree of liberty to its dissatisfied population would usually be capable of conducting its affairs in such a manner as to overcome any existing disaffection or to avoid its inception in the first place. Nor would such a state be capable of fostering secessionist movements within the confines of neighboring countrics in the hope of finally adding suppressed minorities, once they are liberated, to its own citizen body.

No state can, at the present time, from the point of view 
of constitutional law recognize the right of secession founded upon the principle of self-determination. By doing so it would invite its own destruction. For in every modern state there may be found, at one time or other, groups sufficiently dissatisfied with the conduct of the majority or of a ruling minority to demand a release from their allegiance. Such demands are especially likely to occur in a state which in the past has acquired, on the time-honored principle of conquest, groups of populations ethnically foreign to its own racial stock. 


\section{BIBLIOGRAPHY}

Annual Register, The, a Rcview of Public Events at Home and Abroad for the Years I890, I905.

Appleton's American Annual Cyclopacdia and Register of Important Events for the Ycar I86I.

Aulard, F. V. A. Histoire politique de la Révolution française. ... Paris, A. Colin, Igor.

Blumer, Johann Jakob. Staats- und Rechtsgeschichte der schweizerischen Demokraticn. . . . St. Gallen, Scheitlin und Zollikofer, I $850-1850$.

Bonfils, Henri. Manuel de droit international public. . ., ze éd. ... Paris, A. Rousscau, Igor.

Borgeaud, Charles. Histoire du plébiscite ... Le plébiscite dans l'antiquité - Grèce et Rome-Genève, H. Georg, Paris, E. Thorin, I887.

Borgnet, Adolphe. Histoire des Belges à la fin du XVIIIe siècle . ., 2e éd. Bruxelles, A. Lacroix, Verbocckhoven \& cie., I86II 862.

Brown, Philip M. International Relations. . . New York, C. Scribner's Sons, I917.

Cherbuliez, A. E. De la démocratie en Suisse. . . . Paris, A. Cherbuliez et cie., I 843 .

Chuquet, A. M. Jemappes et la conquête de Belgique (1792-1793) . . Paris, L. Cerf, I8go (Les Guerres de la Révolution, IV).

- Mayence. . . Paris, L. Cerf, I892 (Les Guerres de la Révolution, VII).

Compilation of Treaties in Force. Prepared under Resolution of the Senate of February II, I904. Washington, Govt. Printing Office, I904.

David. André. Les plébiscites et les cessions de territoires. Paris, Rousseau et cie.. 1918 (Thèse pour le doctorat. Université de Paris. Faculté de droit).

Deploige. Simon. The Referendum in Switzerland.... translated into English by C. P. Trevelyan. ... Edited with notes ... by Lillian Tomn. ... London, New York, Longmans, Green and Co., 1898 .

Dodd. W. F. The Government of the District of Columbia.... Washington, D. C., J. Byrne \& Co., Igon.

Dunning, W. A. A History of Political Theories, Ancient and Mcdiæval. .. New York, The Macmillan Company, igı6.

- A History of Political Theories from Luther to Montesquieu. ... New York, The Macmillan Company, igí́

Dupanloup, F. A. P. La Souveraineté pontificale sclon le droit catholique et le droit européen.... Paris, Lccoffre, I860.

Edén. Nils. Sweden for Peace. The Programme of Sweden in the Union Crisis. ... Upsala \& Stockholm, Almquist \& Wiksell, Itd.. 1905 .

Flach, Jacques. Les Origines de l'ancienne France, ... Xe et XIe siècles. . . Paris, L. Larose et Forcel, I886-1904. 
France. Archives parlementaires, de 1787 à 1860 . Recueil complet des débats législatifs et politiques des Chambres françaises... fondé par MM. J. Madival et E. Laurent. . . . Paris, P. Dupont, 1867-19-. Series 1, 1787-1799.

Freudenthal, Felix. Die Volksabstimmung bei Gebietsabtretungen und Eroberungen. Eine Studie aus dem Völkerrecht. .... Erlangen, Th. Blaesing, I8gI.

Funck-Brentano, Théophile. Précis du droit des gens. Par Th. Funck-Brentano . . . et A. Sorel . . ., 3e éd. Paris, PlonNourrit et cie., I900.

Gierke, O. F. Political Theories of the Middle Ages, ....translated with an Introduction by F. W. Maitland. . . Cambridge, University Press, I913.

Gjerset, Knut. History of the Norwegian People. . . . New York, The Macmillan Company, igr 5.

Glasson, E. D. Histoire du droit et des institutions de la France. ... Paris, F. Pichon, I887-1903.

Great Britain. Hansard's Parliamentary Debates, vols. 345-347.

Hall. W. E. A Treatise on International Law ..., 5th ed., by J. B. Atlay. . . . Oxford, Clarendon Press, I904.

Hershey, Amos S. The Essentials of International Public Law. . . . New York, The Macmillan Company, igi6.

Hertslet, Edward. The Map of Europe by Treaty; showing the Various Political and Territorial Changes which have taken Place since the General Peace of I814. . . . London, Butterworths, 1875-1891.

International American Conference. Ist. Washington, D. C., I889I 8go. Reports of Committees and Discussions thereon ... (English ed.). Washington, Govt. Printing Office, I89o.

Johnson, W. F. The Story of the Danish Islands. In The North American Review, September, IgI6.

Johnston. Alexander. Popular Sovereignty. In Lalor's Cyclopædia of Political Science, Political Economy, and of the Political History of the United States. . . . Chicago, M. B. Cary \& Company, I883-I 884 .

Jorga, Nicoláe. Geschichte des rumänischen Volkes im Rahmen seiner Staatsbildungen. . . . Gotha, A. Perthes, I905.

King, Bolton. A History of Italian Unity, being a Political History of Italy from I8I4 to I871... . New York, C. Scribner's Sons, I899.

La Gorce, Pierre de. Histoire de ia seconde République française ... se éd. . . . Paris, Plon-Nourrit et cie., Igog.

- Histoire du second empire. . . Paris, Plon-Nourrit et cie., I $904-1908$.

Laveleye, Emile de. Le Régime parlementaire et la démocratic. In Revue des deux mondes. December 15, 1882.

Lavisse, Ernest. Histoire de France depuis les origines jusqu'à la Révolution, publiée avec la collaboration des MM. Bayet, Bloch, Carré. . . . Paris, Hachette et cie., I900-igi I.

Lawrence, $\dot{T} . \dot{j}$. A Handbook of Public International Law . . ., gth ed. London, Macmillan and Co., Itd., I9I5.

Le Bas, Philippe. France. Annales historiques. . . . Paris, Firmin Didot frères. I $840-1843$.

Lewis, V. A. Histnry of West Virginia. In Two Parts. . . Philadelphia, Hubbard Bros., I889. 
Lieber, Francis. De la valeur des plébiscites dans le droit international. In Revue de droit international et de législation comparée, 1871.

Luchaire, Achille. Manuel des institutions françaises. Périodedes Capétiens directs. ... Paris, Hachette et cie., 1892.

McPherson, Edward. The Political History of the United States of America, during the Great Rebellion. . . . New York, D. Appleton \& Co., 1864.

Mano, J. G. L'Union des principantés roumaines, Etude d'histoire diplomatique \& de droit international. [Université de Paris, Faculté de droit] Thèse pour le doctorat. ... Paris, A. Rousseau, igoo.

Markham, C. O. A History of Peru. ... Chicago, H. Sergel and Company, I\&g2.

Martens, G. F. von. Recueil des principaux traités d'alliance, de paix, de trêve ..., conclus par les puissances de l'Europe... depuis I76I jusqu'à présent. . . Gottingue, J. C. Dieterich, I791-I80I.

Méneval, C. F. Memoirs illustrating the History of Napoleon I from I 802 to I815: by Baron Claude François de Méneval. ... Edited by his Grandson, Baron Napoleon Joseph de Méneval. ... New York, D. Appleton and Company, i894.

Meyer, Eduard. Der Ursprung des Tribunats und die Gemeinde der vier Tribus. In Hermes, vol. $\mathrm{xxx}$.

Mohl, Robert von. Staatsrecht, Völkerrecht und Politik. ... Tübingen, Laupp'sche Buchhandlung, I860-I869.

Molinier, Auguste. Etude sur la réunion de Montpellier au domaine royal (I349). In Revue historique, vol. xxiv.

Morley, John M. The Life of William Ewart Gladstone. . . . New York, The Macmillan Company, I903.

Mühlbacher, Engelbert. Dentsche Geschichte unter den Karolingern. .. Stuttgart, J. G. Cotta, 1896.

Müller, Karl O. Geschichten hellenischer Stämme und Städte ..., 2., nach den Papieren des Verfassers berichtigte und vermehrte Ausgabe, von F. W. Schneidewin. ... Breslau, J. Max und Komp., I 844 .

Nordlund, Karl. The Swedish-Norwegian Union Crisis. A History with Documents. .. Upsala \& Stockholm, Almquist \& Wiksell, ltd., I905.

Ollivier, Emile. L'empire libéral; études, récits, souvenirs . . ., [ze éd.]. Paris, Garnier frères, i $895-1015$.

Oppenheim, L. F. L. International Law ..., and ed. London, New York, Longmans, Green and Co., I9I2.

Orsi, Pietro. Modern Italy, 1748-1898 ..., [translated by Mary A. Vialls]. London, T. Fisher Unwin; New York, G. P. Putnam's Sons, 1900 .

Padelletti, G. L'Alsace et la Lorraine, et le droit des gens. In Revue de droit international et de législation comparée, I87I.

Philippe JV, le Bel, King of France. Lettres inédites, publiées aux frais du Ministère de l'instruction publique par l'Académie des sciences, inseriptions, et belles-lettres de Toulouse. Avec une introduction par Ad. Baudouin. Paris, H. Champion, I887.

Picciotto, Cyril M. The Relation of International Law to the Law of England and of the United States of America. . . New York, McBride, Nast \& Company, IgI5. 
Plauchut, Edmond. L'Annexion de l'île Saint-Barthélemy à la France. In Revue des deux mondes, March I5, I879.

Rivier, Alphonse. Principes du droit des gens. . . . Paris, A. Rousseau, I 896 .

Rotteck, K. W. R. von. Abtretung. In Das Staats-Lexikon. Encyklopädie der sämmtlichen Staatswissenschaften für alle Stände. ... Hrsg. von Carl von Rotteck und Carl Welcker..... Altona, J. F. Hammerich, I845-1848.

Rouard de Card, Edgard. Etudes de droit international. . . Paris, G. Pedone-Lauriel, I 890.

Scott, James Brown. The Legal Nature of International Law. In American Journal of International Law, October, I907.

Solière, Eugène. Le Plébiscite dans l'annexion. Etude historique et critique de droit des gens. ... Paris, L. Boyer, I901 (Thèse pour le doctorat. Faculté de droit de Paris).

Stoerk, Felix. Option und Plebiscit bei Eroberungen und Gebietscessionen. . . Leipzig, Duncker \& Humblot, I879.

Ullmann, Emanuel von. Völkerrecht . . Neubearbeitung. . . . Tübingen, J. C. B. Mohr, I908 (Das öffentliche Recht der Gegenwart. ... hrsg. von Dr. G. Jellinek ..., Dr. P. Laband ..., Dr. R. Piloty ..., bd. iii).

Vincent, John Martin. State and Federal Government in Switzerland. ... Baltimore, Johns Hopkins Press, I89I.

Westergaard, W. C. The Danish West Indies under Company Rule (1671-1754). With a Supplementary Chapter, 1755-1917... New York, The Macmillan Company, I917.

Westlake, John. The Collected Papers of John Westlake on Public International Law, edited by $L$. Oppenheim. . . . Cambridge, University Press, 1914.

Willoughby, W. W. The Constitutional Law of the United States. . . New York, Baker, Voorhis \& Company, I9ı.

- The Legal Nature of International Law. In American Journal of International Law, April, I908.

The Political Theories of the Ancient World. . . . New York, London, Longmans, Green and Co., 1903. 



\section{INDEX}

"Agreement of the people" of I647. See England.

Alsace-Lorraine, annexations by France confirmed in Treaty of Muenster (I648), 53; indemnity to German princes for abolition of feudal rights by revolutionary France, 59 (note) ; annexation by Germany (I8-I), I45-I49, I66, I74-I76; cession by Germany to France (1919), see Versailles, Treaty of.

American Conference, First International. See International American Conference, First ( I890).

Argyll Duke of, opposed to plebiscite in Alsace-Lorraine (I87I), I75-I76.

Asquith, Herbert H., on selfdetermination, $\mathbf{I} 77$.

Assembly vote in ancient Greece. See Greece.

Austria, Peace with Allied and Associated Powers. See St. Germain, Treaty of.

Avignon and Venaissin, vote for annexation to revolutionary France, 56,59 ; intervention by France, 58, 60; Papal protests, 59,60 (note).

Baltic States, independence by assembly vote or by direct popular vote, I28-I30, I55. See also Brest-Litovsk, Treaty of.

Basel, bishopric under German sovereignty, resolution renouncing allegiance, $6 \mathrm{I}-62$; intervention by revolutionary France, 63; vote for annexation to France, 63.

Belgium, declares itself republic, free from Austrian sover- eignty ( 1790$), 68$; reduced to former status, 69; intervention against Austria by revolutionary France, 66 ff. ; French decree of Dec. I5, I792, prepares for annexation to France, 7I-72; opposition to annexation, $7 \mathrm{I}-72$; propaganda of political clubs organized by French commissioners, 72-74; votes for annexation, 74 .

Bingen. See Mainz.

Bonfils, Henri, on cession, 29 (note), 30 (note); on option, I63.

Bourgeoisie, definition of feudal, $35,4 \mathrm{I}$; relation to liege lord, $35-36,40,42$; relation to king as suzerain of liege lord, 37, 40.

Brest-Litovsk, Treaty of, no plebiscites for Baltic States, Lithuania and the Ukraine, I28-I 30 .

British Labor Party, Program of peace, 154.

Brittany, remonstrances by royal courts of, 24 (note).

Bucharest, Treaty of, no plebiscites provided, 130 .

Bulgaria, Peace with Allied and Associated Powers, I5o (note).

Cavour, becomes guiding statesman of Piedmont (1852), 86; resigns after king signs Preliminary Peace of Villafranca ( I859), 87; becomes premier again (I860), 89. See also Italian States; Plombières.

Cession, modes of, 29. See also Bonfils; Hall; Hershey; Oppenheim: United States Supreme Court; Willoughby.

Chile, annexation of Tacna and Arica. See Tacna and Arica. 
Consent, popular. See Popular consent.

Constitutional convention vote deemed equivalent to plebiscite in American constitutional theory, int (note).

Courland, German population, 155. See also Baltic States.

Danish West Indies, plebiscite for annexation to United States, 125. 172-173; assembly vote on annexation in Denmark, I25; popular vote, I26.

Danzig. See Versailles, Treaty of.

Declaration of the rights of man and citizen, 24, 54 .

England, "Agreement of the people" of $1647,20,23$ (note).

Esthonia. See Baltic States.

Etats Généraux, registration of treaties stipulating eession of French territory, $47-50$.

Eupen. See Versailles, Treaty of.

Expatriation, enforced, I 54.

Fendalism, relation of seigneur and vassal, 32-33; consent of vassal to transfer of fief, 33 , 40; relation of king, seigneur and vassal, 33-34, 36; transfer of territory, 33-36; definition of people, 35,37 ; consent of entire French nation required to cession of part of French territory to foreign sovereignty, 46-47; popular consent to change of allegiance, see Bourgeoisie; Etats Généraux.

Fief, alicnation of. See Feudalism.

Finland, independence by assembly vote, I 55 .

France, plebiscite in internal atfairs (1848-1852), 23-27; revolutionary, renounces conquest. 54 ; no conquest does not mean no annexation, 76 ; revolutionary, passes decree promising aid to all peoples sceking political freedom, 6r (note); warned by England against intervention, 6I (note); asked for aid by Republic of Rauracie, 62 ; revolutionary, passes decree stipulating overthrow of old, and establishment of revolutionary, governments in all countries where French troops enter, 72 ; passes decree threatening with death attenipt or proposal to cede French territory, 79 (note).

Fivlbert de Chartres, on relation of vassal and liege lord, 34, 36 .

Geneva, assembly vote against annexation to Savoy (1240), 44; annexation to France ( i 798 ), 76 (note), i65.

Germany, assembly votes of old German tribes, I9-2I; disappearance of assemblies, 20 , I06; peace with Allied and Associated Powers, see Versailles, Treaty of.

Gex, remonstrance of, 23-24.

Gladstone, opposes plebiscite in Heligoland, II2; favors plebiscite in Alsace-Lorraine, I/4Iт6.

Greece, ancient, assembly votes in internal affairs, I6-19, I97I 2 ; no popular consent recognized in foreign relations of, $3 I$.

Grey, Sir Edward, on self-determination, 177.

Guéromnière, de la, on eession of French territory in feudal times, 49.

Guyenne, proposed cession by France to England (1344), $46-47$.

Hall, W. E., on cession and plebiscite, I7I-I72.

Hawaiian Islands, plebiscite proposed by Japan, opposed by United States. I73-I74.

Heligoland, plebiscite proposed for cession to Germany, I I II 12 , I 88 .

Hershey, A. S., on cession and plebiscite, Iтح.

Hertling, Georg Friedrich von, on self-determination, $178,189$. 
Hungary, Peace with Allied and Associated Powers, I50.

International American Conference, First, I 890 , resolutions against conquest and for arbitration on American continent, I8o.

Inviolability of French soil, 47, 53, 79 (note), I74-I75, I84 (note).

Ionian Islands, assembly votes for union with Greece (I854I859), II 4-II 5 .

Ireland, I52.

Italian States, beginning of revolution against oppressive governments, $81-82$; revolutionary movements against foreign rule and princes imposed in I8I5, 8I-82; revolt against Austrian rule in LombardoVenetian States, 8I, 83-84; inconclusive plebiscites for union with Piedmont ( 1848 ), 84-86; inconclusive plebiscites (I859), 87-88; final plebiscites ( 1860 ), 89 , 9I-92; decrees of annexation, $89-90,92$; protests of the Pope and deposed princes, 909I; final plebiscite in Venetia ( 866$)$, 92-93; plebiscite in Rome (I870), 93-94.

Klagenfurt area, plebiscites. See St. Germain, Treaty of.

Landau. See Mainz.

Laveleye, Emile de, on plebiscite and referendum, II (note), I2 (note).

Leobschütz (Kreis). See Versailles, Treaty of.

Lex, distinguished from plebiscitum, I3.

Lieber, Francis, on plebiscite, I 2 (note).

Lithuania, independence of, I29, I53.

Livonia. See Baltic States.

Lloyd George, on self-determination, I77-I78, I89.

Lombardy. See Italian States.

Luxemburg. proposed annexation to France by plebiscite ( I867), IO9-I IO.
Lyons, citizens express desire for sovereignty of King of France (end of I3th cent.), 38 ; citizens and nobles called upon to sanction treaty of I $307,38-40$.

Mainz, Worms, Speier and territory to left of Rhine between Landau and Bingen, intervention by revolutionary France, 74 ; vote for annexation to France, $74-75$; opposition to annexation, $75-76$; measures to overcome opposition, 76 .

Majorca, kingdom, annexed to Aragon without consultation of people, 45.

Majorities and minorities in ceded or seceding territories. See Minorities.

Malmédy. See Versailles, Treaty of.

Marseilles, citizens give city in public meeting to House of Toulouse, 40-4I.

Mayence. See Mainz.

Memel. See Versailles, Treaty of.

Metz, annexation by France (I552) without consent of population, $5^{0-53}$.

Milan. See Italian States.

Minorities in ceded or seceding territories, I6I-I63, I98-202. See also Option.

Modena. See Italian States.

Moldavia. See Valachia and Moldavia.

Montpellier, no popular consent in passing of barony to King of Aragon (1236), 44; no popular consent in assumption of suzereignty of King of France (1293), 44; King of Majorca, holding arrière fief rights, solicits support of inhabitants against suzereignty of King of France, $44-45$.

More, Thomas, on popular consent, 23.

Moresnet. See Versailles, Treaty of.

Mülhausen, annexation by France (I798), 76 (note), I65. 
Napoleon I, coup d'état by plebiscite of $I 7(x), 25-26$; consul for life by plebiscite of I802, 26 ; emperor by plebiscite of 1804, 27.

Napoleon III, president of France by plebiscite of 1848 , maintenauce of authority by plebiscite of $185 \mathrm{I}$, hereditary emperor by plebiscite of 1852 , 27, I57; withholds and grants comsent to Italian plebiscites, 89, 93, 97; sponsor of plebiscite and self-determination, 93, 96 (note), I03-I04, I06-Io8, IIO.

Nice, intervention by revolutionary France, $66-67$; vote for aunexation to France, $66-67$; annexed (1793), 67; promised Napoleon IIl by Cavour at Plombières (1858), 86, 89, 93, $97-98$; promised by secret and public agreements (1860), g8 (note); cession to France ( 860$)$, 97-99. See also Savoy.

Norway, separation from Sweden by plebiscite (I904), II2I I 4, I 5 I-I 52 .

Oppenheim, L., on cession and plebiscite, 28 (note), 30 (note), 127.

Option, history and principle of, I 29, I $3 \mathrm{I}^{-1} 32, \mathrm{I} 38$, I 45, I 47, I63I67. See also Bonfils; Rivier; Ullmann; Willoughby.

Orlando, Vittorio, on self-determination, 178 .

Padelletti, G., on plebiscite, I99 (note).

Padua. See Italian States.

Pamiers, people agree by acclamation to change of overlordship ( I285), 42 .

Parma. Sce Italian States.

Peru, cession of Tacna and Arica. See Tacna and Arica.

Piacenza. See Italian States.

Pichou, Stephen, on self-determination, I 78 .

Plebiscite, definition and origin of, 11-I2, I96-I98; executive, I2 (note); legislative, I2 (note); national (in internal affairs), I2 (note), 97, I5I, I6I; annexationist or international, i2 (note); in international relations, meaning and purpose of, I2, 95-96, I5I-I52, I6I, I08-20I ; criticism of conduct of, $26,50-51,56-57,59-$ $60,63-64,67,73-76,85,88-89$, $90^{-9} 91$, 94-95, II6, I57-I63; as applied by revolutionary France, 78-79; not recognized in Europe outside of revolutionary France, $79-8 \mathrm{I}$; in territory under military occupaton by conqueror, I54-I55, I 59; on restricted franclise, I59I6I; by simple or larger majority, $161-163,201-202$ : as state policy, I68; advocates and opponents of, I7I, I88-I89, ig9 (note).

Plebiscitum. See Rome.

Plombières, agreement of (1858), 86, 89, 93, 97-08.

Pommern. See Versailles, Treaty of.

Popular consent, definition of, I I, 28; opposed by United States, I25, I72-I74; opposed by England, I I I-I I2, I 88 . See also Plebiscite, in international relations; Self-determination.

Popular sovereignty, proclaimed by revolutionary France, 24, 29-30; extended to international relations, 77 ; not recognized by states outside of France, 8o; gains recognition in national life of Western Europe, 8I ; acclaimed by Italian States, 8I ff. See also Squatter sovereignty.

Posen. See Versailles, Treaty of.

Prussia, East, separated geographically from Germany. I 54 (note). See also Versailles, Treaty of.

Prussia, West. See Versailles, Treaty of.

Rauracie, Republic of. See Basel.

Referendum, definition of, II. 
Rivier, Alphonse, on plebiscite and popular sovereignty, 30 (note) ; on option, I63.

Romagna. See Italian States.

Rome, ancient, plebiscite in internal affairs of, I2-I6, I8-I9, I97-Igs; no popular consent recognized in foreign relations of, 3I; plebiscite in modern ( 1870$)$, 93-94.

Rotteck, K., on conquests of ancient Greece and Rome, 3I.

Rouard de Card, on plebiscite, 49.

Roumania. See Valachia and Moldavia.

Rovigo. See Italian States.

St. Bartholomew, plebiscite for union with France (I877), I I 5-I I6.

St. Croix. See Danish West Indies.

St. Germain, Treaty of, plebiscite provided for Klagenfurt area only, I50; result of plebiscite held, I50 (note); Austria denied right to join Germany without consent of League, I 50 .

St. John. See Danish West Indies.

Savoy, intervention by revolutionary France, $64-65,76$ (note); vote for annexation to France, 66 ; return of part of, by canvass of signatures (I8I5), \&o (note); promised by Cavour to Napoleon III, 86 , $89,93,97-98,98$ (note) ; cession to France by plebscite (1860), 97-IOI ; cession of, as infringement upon Swiss rights, I00IOI. See also Cavour.

Schleswig, Northern, plebiscite proposed in 1864 , I06-107; provided in Art. $V$ of Treaty of Prague (I866), I08-I Io, I25 (note); Art. $\mathrm{V}$ eliminated (1878), rog-i io. See also Versailles, Treaty of.

Self-determination, as applied by revolutionary France, 77; not recognized by Europe outside of France, 80; not applied by imperial France, 80-8I, I65; Allied and Associated Powers demand peace on basis of, I28, I76-I78; Central Powers consent to, I54-I55, I78-I79; by direct (popular) or indirect (assembly) vote, I 55-I56; scope and aim of, I55 (note), I6II63; danger to State, I63, I67I70, 202-203; for uncivilized peoples, I89-Igo; forces working for recognition of, I82I83, I88-I92; forces working against recognition of, $\mathbf{1} 83^{-}$ I88; status in constitutional law, I83-I88, 202-203; status in international law, 5I, I8I, I92-I95; advocates and opponents of, I7I, I88-I89, I99 (note); policy of state in regard to, I68. See also Popular consent.

Seward, W. H., on plebiscite. See Danish West Indies.

Sherman, John, on plebiscite. See Hawaiian Islands.

Silesia. See Versailles, Treaty of.

Spanish-American War, American Peace Commission, on popular consent, I74.

Speier. See Mainz.

Squatter sovereignty, I23-I 25.

Suffrage, universal, and the plebiscite, I2, 26.

Switzerland, plebiscite in, I I-I2, 20-2I, 24. See also Savoy.

Tacna and Arica, annexed by Chile (I884) on condition of plebiscite to be held after ten years, 126

Tahiti Islands, chiefs consulted regarding cession to France ( I880), I I6 (note).

Thiers, on plebiscite. See Alsace-Lorraine; Inviolability of Fiench soil.

Toul, annexation by France (1552) without consent of population, $50-53$.

T:eviso. See Italian States.

Turkey, Peace with Allied and Associated Powers, I50 (note). Tuscany. See Italian States. 
Ukraine, independence by assembly vote, I55. See also Brest-Litovsk, Treaty of.

Ullmann, Emmanuel von, on option, I63.

United States, plebiscites, retrocession of part of District of Columbia, 117 ; secession movement, II7-123; secession of West Virginia from Virginia, I 19-123, 168, I70.

Valachia and Moldavia, union on basis of essembly votes, $101-106$.

Venaissin. See Avignon and Venaissin.

Venetia. See Italian States.

Venezuelan Congress criticises conquest by Chile (I884), I 80.

Venice. See Italian States.

Verdun, annexation by France (1552) with appeal to "free vote of the people," 50-53.

Versailles, Treaty of, cessions by Germany to be dependent on plebiscites: Eupen and Malmédy, I31-I34; Northern Schleswig, I38-I39, I99-20I ; parts of provinces of East and West Prussia and Upper Silesia, I40-I42; Saar Valley, plebiscite to decide sovereignty after 15 years of foreign rule, $134^{-1} 38$; results of plebiscites held in East and West Prussia and Northern Schleswig, I50 (note), 200; cessions without plebiscites: Moresnet, I3I-I34; Saar Valley, I5 years of foreign rule without plebiscite, 134-138; parts of provinces of Posen, West Prussia, Pommern, I40-142; Danzig, I42I44; Memel, I44-I45; part of province of Silesia, I45; Kreis Leobschütz, conditionally, I45; German colonies, I45-146; Alsace-Lorraine, I46-149, I 52I53.

Vicenza. See Italian States.

Villafranca, Preliminary Peace of, 87 .

Voltaire, on plebiscite, 23-24.

Willoughby, on cession, 29 (note); on popular consent in American constitutional law, I $85-188$.

Wilson, Woodrow, on self-determination, $176-\mathbf{7 7 7}$.

Worms. See Mainz.

Zürich, Treaty of, $92,98$. 


\section{VITA}

Johannes Mattern was born in Rheinland, Germany, Janwary I9, I882. He studied Classical and Germanic Philology and Literature. Philosophy, History and Education at the Universities of Muenster and Bonn, during the Academic years 1904-1907. In the early part of 1907 he came to the United States and has become a naturalized American citizen.

He has occupied the following positions: 1907-1909, instructor at Chevy Chase College and Seminary, Chevy Chase, Md.; I909-1910, Cataloguer in the Library of Congress, Washington, D. C.; I9IO-I9II, reorganizer of the Library of the Bureau of Statistics of the United States Department of Commerce and Labor; since I9II, Assistant Librarian of The Johns Hopkins University.

In his work at the Library of Congress and the Bureau of Statistics he had occasion to specialize in the Social Sciences. While holding the position of Assistant Librarian of The Johns Hopkins University he has studied Political Science at this University since October, 19I7, with History of Philosophy and History of Education as subordinate subjects. 






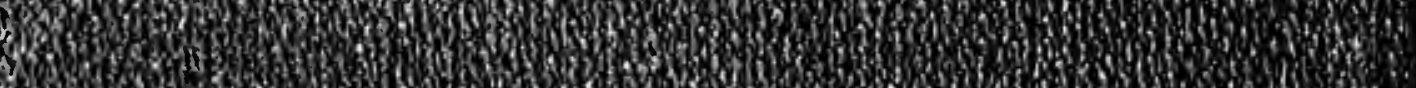

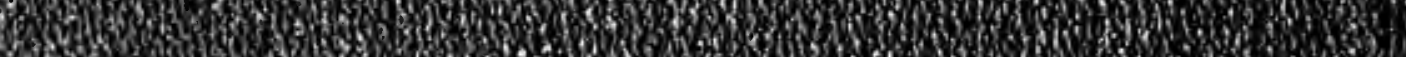
20.6.

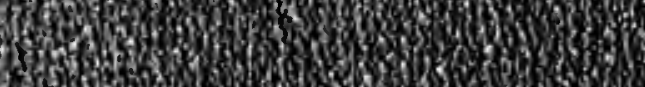

350 .

3.

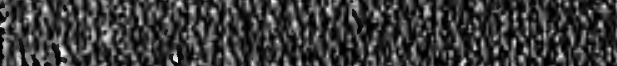

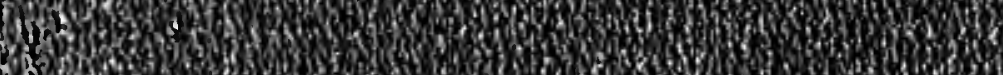
for

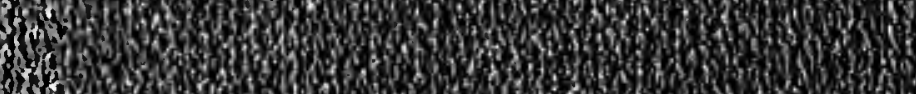

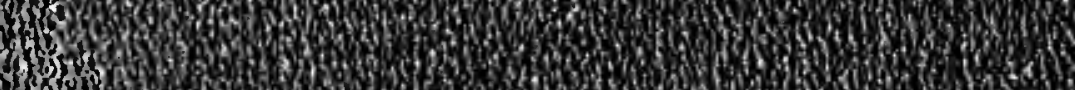

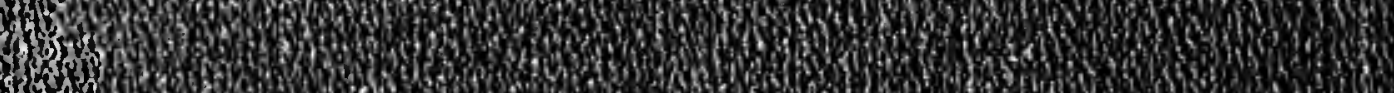

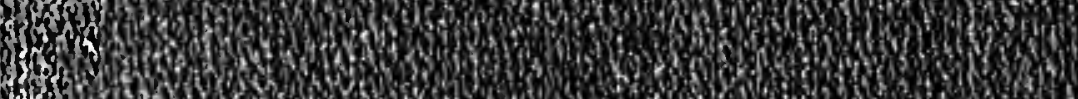

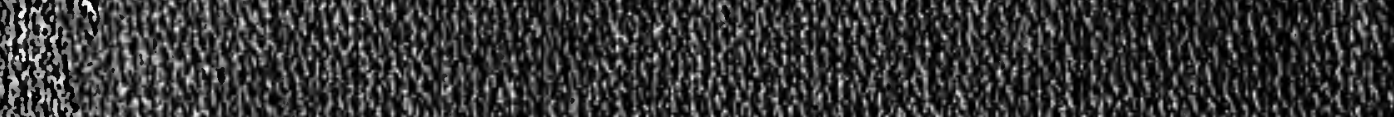
4 to

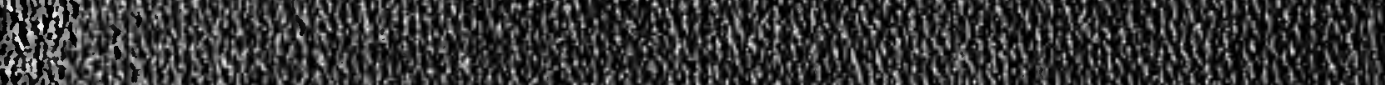

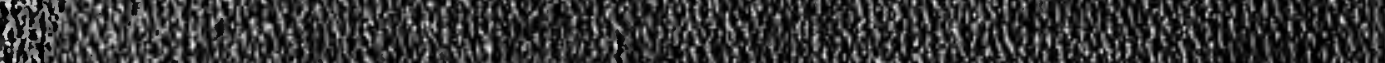

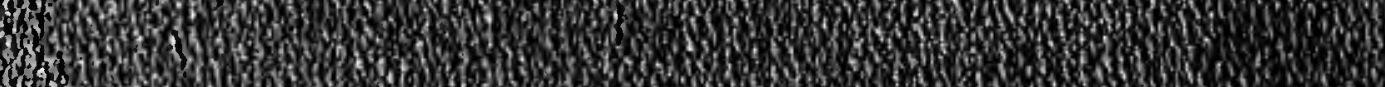
8 W.

Y.

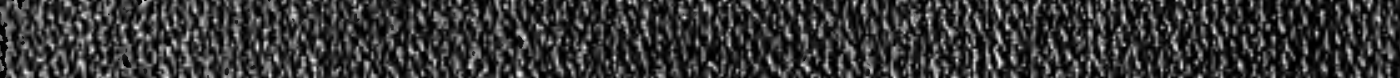

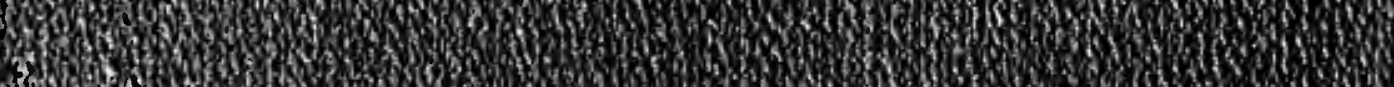

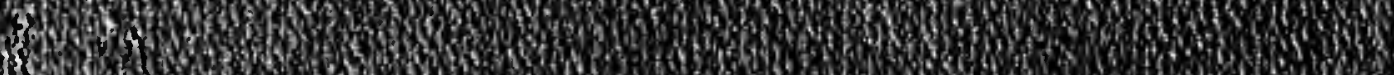
X.

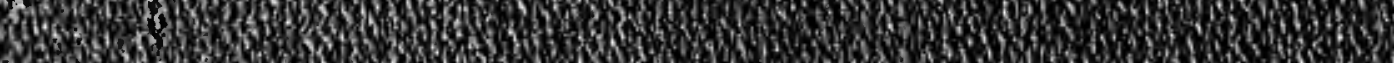
a.

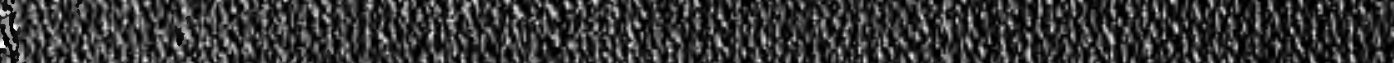
36 . 3 (3)

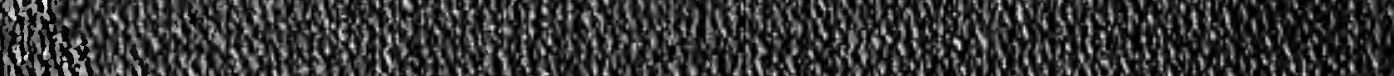

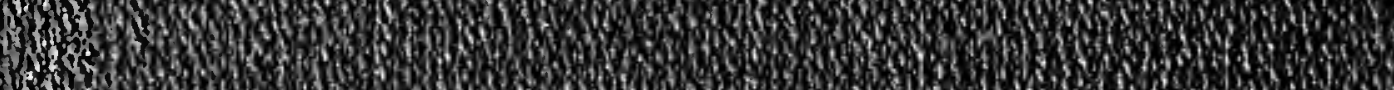

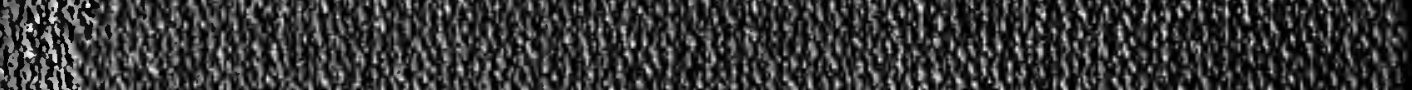
31N) H. 20 .

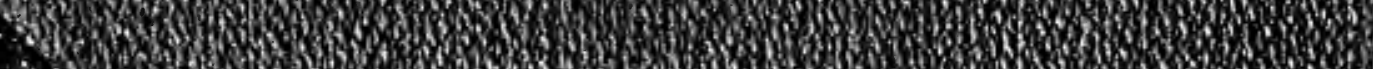
a 3 (1) C.5. S.

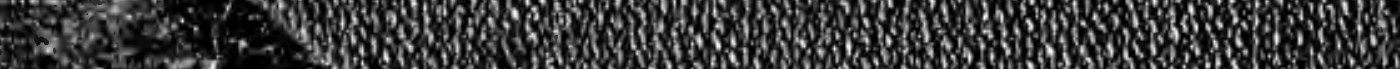

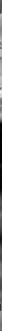

